UNIVERSIDADE ESTADUAL PAULISTA "JÚLIO DE MESQUITA FILHO"

Campus de São José do Rio Preto

Gisele Baldissera

\title{
Análise Conformacional dos Peptídeos Protonectina e Protonectina (1-6), Isolados e em Associação, em Mistura TFE-Água.
}

São José do Rio Preto

$-2010-$ 


\title{
Gisele Baldissera
}

\section{Análise Conformacional dos Peptídeos Protonectina e Protonectina (1-6), Isolados e em Associação, em Mistura TFE-Água.}

\author{
Dissertação apresentada para obtenção do título \\ de Mestre em Biofísica Molecular, área de \\ concentração Biofísica Molecular, junto ao \\ programa de Pós-Graduação em Biofísica \\ Molecular do Departamento de Física do Instituto \\ de Biociências, Letras e Ciências Exatas da \\ Universidade Estadual Paulista "Júlio de \\ Mesquita Filho", Campus de São José do Rio \\ Preto, São Paulo, Brasil.
}

Orientador: Prof. Dr. José Roberto Ruggiero

Co-Orientador: Prof. Dr. Jorge Chahine

São José do Rio Preto $-2010-$ 
Gisele Baldissera

\section{Análise Conformacional dos Peptídeos Protonectina e Protonectina (1-6), Isolados e em Associação, em Mistura TFE-Água.}

Dissertação apresentada para obtenção do título de Mestre em Biofísica Molecular, área de concentração Biofísica Molecular, junto ao programa de Pós-Graduação em Biofísica Molecular do Departamento de Física do Instituto de Biociências, Letras e Ciências Exatas da Universidade Estadual Paulista "Júlio de Mesquita Filho", Campus de São José do Rio Preto, São Paulo, Brasil.

BANCA EXAMINADORA

Prof. Dr. José Roberto Ruggiero

Professor adjunto

UNESP - São José do Rio Preto

Orientador

Prof. Dr. Pedro Geraldo Pascutti

Professor adjunto

UFRJ - Rio de Janeiro

Prof. Dr. Márcia Perez dos Santos Cabrera

Doutor

UNESP - São José do Rio Preto 
"A cada día que vivo, mais me convenço de que o desperdício da vida esta no amor que não damos, nas forças que não usamos, na prudência egoista que nada arrisca, e que, esquivando-se do sofrimento, perdemos também a Felicidade"

Carlos Drummont de Andrade 


\section{Agradecimentos}

Agradeço primeiramente a Deus, pois sem sua constante presença em minha vida, nenhuma de minhas conquistas tería sido possível.

Ao Professor $\mathcal{D} r$. José Roberto Ruggiero, que me orientou durante esses anos, contríbuindo para o meu crescimento intelectual e profíssional e acima de tudo por sua amizade.

$\mathcal{A}$ todos os professores do departamento de física, em especial, ao Professor Dr. Jorge Chahine, meu co-orientador, que contribuiram para minha formação.

$\mathcal{A}$ Professora Dr. Márcía dos Santos Peres Cabrera e à Dr. Sabrina

Thais Broggio Costa, pela contríbuição no desenvolvimento deste trabalho, através de muitas discussões e valiosas sugestões.

Aos integrantes do grupo, príncipalmente a Tamara, amiga com a qual discuti muitos resultados e problemas encontrados durante o desenvolvimento deste trabalho.

A toda minha familia, em especial aos meus pais, Geraldo e Terezinha que me deram suporte para que eu tivesse uma boa formação profíssional. Por ser o esteio da minha vida, pela educação que recebi e por tudo o que tenho e sou hoje.

$\mathcal{A}$ minha irmã Laura, agradeço pela compreensão, apoío e amizade.

As minhas amigas Franciele, Karina e Natália que sempre estiveram comigo nos melhores momentos e também nos piores, com muito bom humor e cumplícidade.

Aos meus amigos Marcelo, Fabricio, Gabriel, Kuririm e a todos os amigos com os quais dividi alguns momentos dessa jornada.

E finalmente, agradeço a CAPES pelo suporte financeiro. 


\section{RESUMO}

Protonectina e Protonectina 1-6 são peptídeos extraídos do veneno da vespa social Agelaia pallipes pallipes. O primeiro apresenta atividade hemolítica, de degranulação de mastócitos e quimiotática, enquanto o segundo apresenta somente a atividade quimiotática quando atuam isoladamente. A associação destes dois peptídeos, em proporção 1:1 produz um aumento nas atividades hemolíticas e de degranulação de mastócitos, enquanto a atividade quimiotática decresce acentuadamente, ou seja, em associação apresentam um comportamento mais acentuado de interação com membranas. Dados de dicroísmo circular mostram que, quando associados, há um pequeno acréscimo no percentual de aminoácidos em conformação de hélice- $\alpha$. A proposta deste trabalho é analisar, usando dinâmica molecular, os aspectos conformacionais da Protonectina isolada e em associação com a Protonectina $1-6$ em misturas de TFE-água, para entender se e como ocorre essa associação, procurando destacar quais fatores podem ser determinantes nesse processo.

A Protonectina isolada foi estudada por meio de dinâmicas moleculares de equilíbrio e dinâmica associada ao método de troca de réplicas. Com esse método, obteve-se dezesseis trajetórias de $60 \mathrm{~ns}$ varrendo o intervalo de temperaturas de 287 a $342 \mathrm{~K}$, usando uma conformação em hélice alfa ideal como estrutura inicial. Usando o software WHAM e parâmetros como o RMSD e a primeira das componentes de uma Análise de Componentes Principais, PCA, como coordenadas de reação, obteve-se a superfície de energia livre, que apresenta dois mínimos principais. O mínimo com energia mais baixa contém estruturas ordenadas, com parte dos resíduos em alfa-hélice, ou em hélice-5 ou, ainda, numa combinação de "turns" e B-bridges, enquanto conformações aleatórias são encontradas no segundo mínimo. Destes dados o tempo de transição entre estes estados foi obtido. A partir de estruturas típicas encontradas nas dinâmicas usando troca de réplicas, obtiveram-se seis trajetórias de equilíbrio de aproximadamente 60 ns. Essas dinâmicas comprovam certa estabilidade das estruturas encontradas no mínimo de energia.

A associação da protonectina com a protonectina $1-6$ foi estudada em uma simulação de equilíbrio de aproximadamente 300 ns de duração na temperatura ambiente. Os resultados sugerem que há um aumento na quantidade de resíduos ordenados na Protonectina. O processo de associação é promovido pela presença de ligações de hidrogênio entre as duas moléculas e a eliminação de solvente da região entre elas e parece induzir a formação de uma 
região anfipática, que pode ser correlacionada ao aumento das funções biológicas destes peptídeos quando associados, embora isso ainda demande mais investigação.

PALAVRAS-CHAVE: Dinâmica Molecular, Método de Troca de Réplicas, Protonectina. 


\section{ABSTRACT}

Protonectin and Protonectin 1- 6 are peptides extracted from the venom of the social wasp Agelaia pallipes pallipes. While Protonectin presents hemolytic, mast cell degranulation and chimiotactic activities, protonectin 1-6 just presents the chimiotactic activity. When these peptides are mixed at 1:1 molar ratio the hemolytic and mast cell degranulation activities increase while the chemiotactic decreases significantly. Circular Dicroism data shows a small increase in the amount of residues in ordered structures, alfa helix, for example. The purpose of this work is to analyse the conformational features of these peptides isolated and in association in TFE-water mixtures using molecular dynamics simulation to understand if this association occurs or not and how.

The Protonectin was studied using equilibrium MD simulations and associating Molecular dynamics and the replica exchange methods. With this method, sixteen trajectories of the $60 \mathrm{~ns}$ in the range $287-342 \mathrm{~K}$ was simulated, all the replicas starting from an ideal alfa helix. Using the WHAM software, RMSD parameters and the first Principal Components Analysis, PCA, we have the free energy surface, that presents two principals minimums. One corresponding to structures with some organization some residues in $\alpha$-helix, 5-helix or turns associated with b-bridges. The other minimum presents structures in coil conformation. The "folding" time were stimated and the stability of the conformations are discussed. Starting from typical structures found in the equilibrium dynamic associated with the replica exchange method six 60 ns trajectories were simulated. These simulations comprove some stabilization of the structures found at the energy minimum.

The association of Protonectin and Protonectin 1- 6 was studied using equilibrium molecular dynamics run during at $\sim 300 \mathrm{~ns}$ in the ambient temperature. The results suggest that there is an increase in the amount of organized residues in Protonectin. The association process it is promoted by hydrogen bonds between the peptides that leads to an amphyphatic stucture, which may be responsible for the increase in the biological functions of the peptides, when they associate. However these biological aspects require further investigation. 


\section{LISTA DE FIGURAS}

1.1.1 Representação dos mecanismos de ação com membranas dos peptídeos antimicrobianos.............4

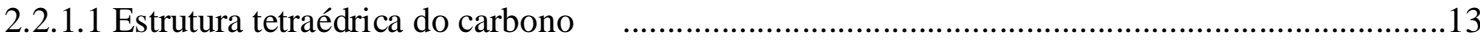

2.2.2.1 Rotação em torno da ligação covalente entre dois átomos........................................................14

2.2.3.1 Representação do Potencial de Lennard Jones para o Carbono...................................................15

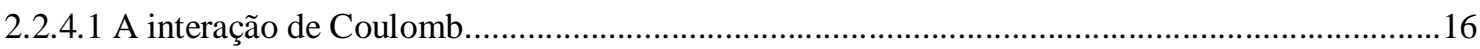

2.5.2.1 Esquema bidimensional das Condições de Contorno Periódicas.................................................23

2.6.1 Conformação de partida da simulação da Protonectina associada com a Protonectina 1-6..........25

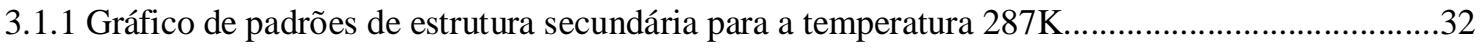

3.1.2 Gráfico de padrões de estrutura secundária para a temperatura 290K..........................................33

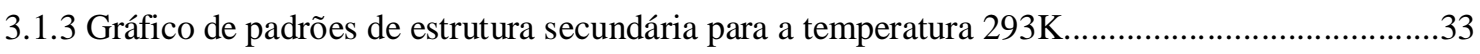

3.1.4 Gráfico de padrões de estrutura secundária para a temperatura 296K. ......................................33

3.1.5 Gráfico de padrões de estrutura secundária para a temperatura 299K. ........................................34

3.1.6 Gráfico de padrões de estrutura secundária para a temperatura $302 \mathrm{~K} \ldots \ldots . . . . . . . . . . . . . . . . . . . . . . . . . . . . . . . . .34$

3.1.7 Gráfico de padrões de estrutura secundária para a temperatura 306K. .......................................34

3.1.8 Gráfico de padrões de estrutura secundária para a temperatura $310 \mathrm{~K}$........................................35

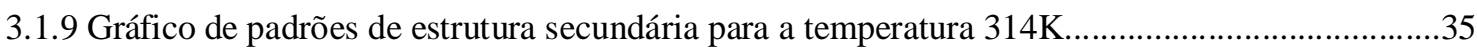

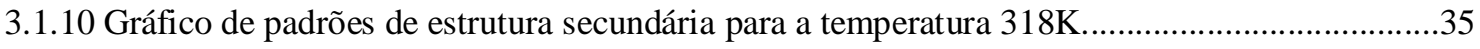

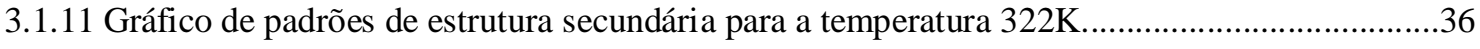

3.1.12 Gráfico de padrões de estrutura secundária para a temperatura 326K.......................................36

3.1.13 Gráfico de padrões de estrutura secundária para a temperatura 330K.......................................36

3.1.14 Gráfico de padrões de estrutura secundária para a temperatura 334K.......................................36

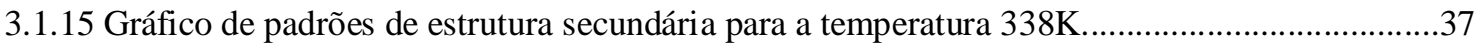

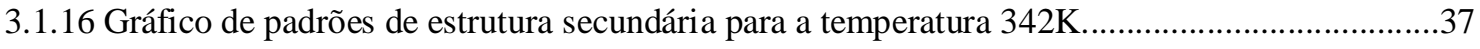

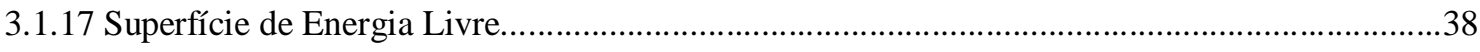


3.1.18 Estruturas organizadas obtidas no primeiro mínimo de energia livre 39

3.1.19 Conformações em coil obtidas no segundo mínimo de energia. .39

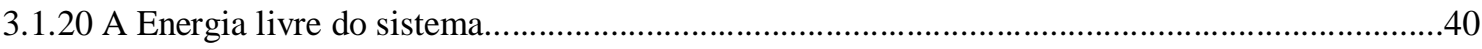

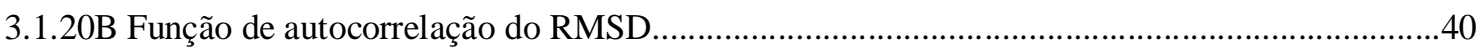

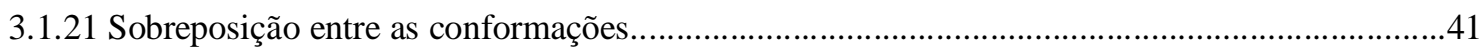

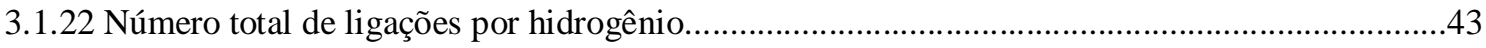

3.1.23 Análise dos diedrais, $\varphi$ e $\psi$, de alguns resíduos da Protonectina para a réplica de $299 \mathrm{~K} . . . . . . . . . .44$

3.2.1 Gráficos dos padrões de estrutura secundária para as simulações de equilíbrio ...........................47

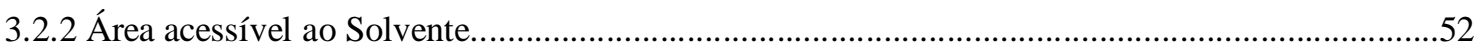

4.1 Gráfico de Padrões de Estrutura Secundária para a simulação da Protonectina associada com

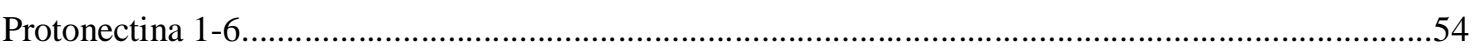

4.2 Ligação de hidrogênio entre a Protonectina e a Protonectina 1-6.....................................................57

4.3 Soma do número de ligações de hidrogênio entre a Protonectina e a Protonectina 1-6...................58

4.4 Distância entre o centro de massa da Protonectina e o centro de massa da Protonectina 1-6 como

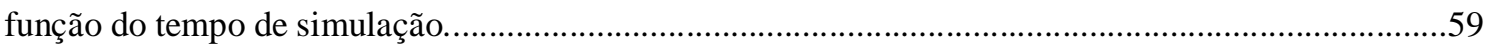

4.5 Energia Potencial Total entre a Protonectina e a Protonectina 1-6...............................................60

4.6 Disposição dos peptídeos Protonectina e Protonectina 1-6 depois de associados.............................60

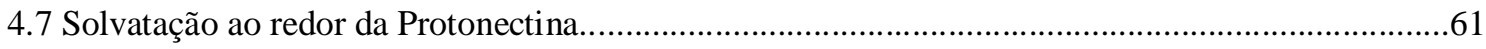




\section{LISTA DE TABELAS}

1.1.1 Seqüência Primária dos Peptídeos Mastoparano X e Polybia MP1 ..................................................2

1.3.1 Seqüência primária da Protonectina e Protonectina 1-6

1.3.2 Propriedades biológicas da protonectina, protonectina 1-6 e associação de ambos os peptideos...6

1.3.3 Conteúdo helicoidal da Protonectina e mistura (1:1) da Protonectina e Protonectina 1-6.............7

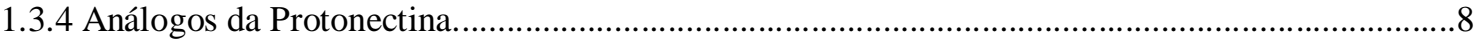

3.1.1 Valores de RMSD para conformações sobrepostas.......................................................................42

3.2.1 Relação das simulações e suas respectivas conformações iniciais..................................................45

3.2.2 Porcentagem de permanência das conformações obtidas durante as simulações.......................... 48

3.2.3 Porcentagem de permanência dos diferentes tipos de Ligações de hidrogênio entre os grupos CO

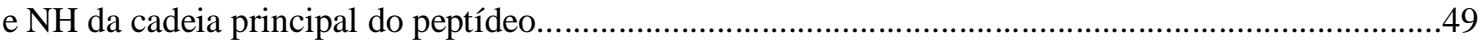

3.2.4 Porcentagem de permanência das Ligações de hidrogênio entre o grupo NH de cada resíduo da cadeia principal do peptídeo e as moléculas de água ou TFE...............................................................50

4.1 Tempos de permanência das ligações de hidrogênio do tipo $\mathrm{N}-\mathrm{N}+4$ e N $-\mathrm{N}+5$ da Protonectina

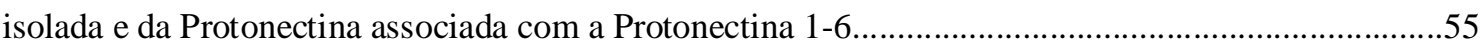

4.2 Porcentagens de permanência das Ligações de hidrogênio entre o grupo NH de cada resíduo da cadeia principal da protonectina associada e as moléculas de água ou TFE .55 


\section{Lista de Símbolos, Siglas e Abreviaturas}

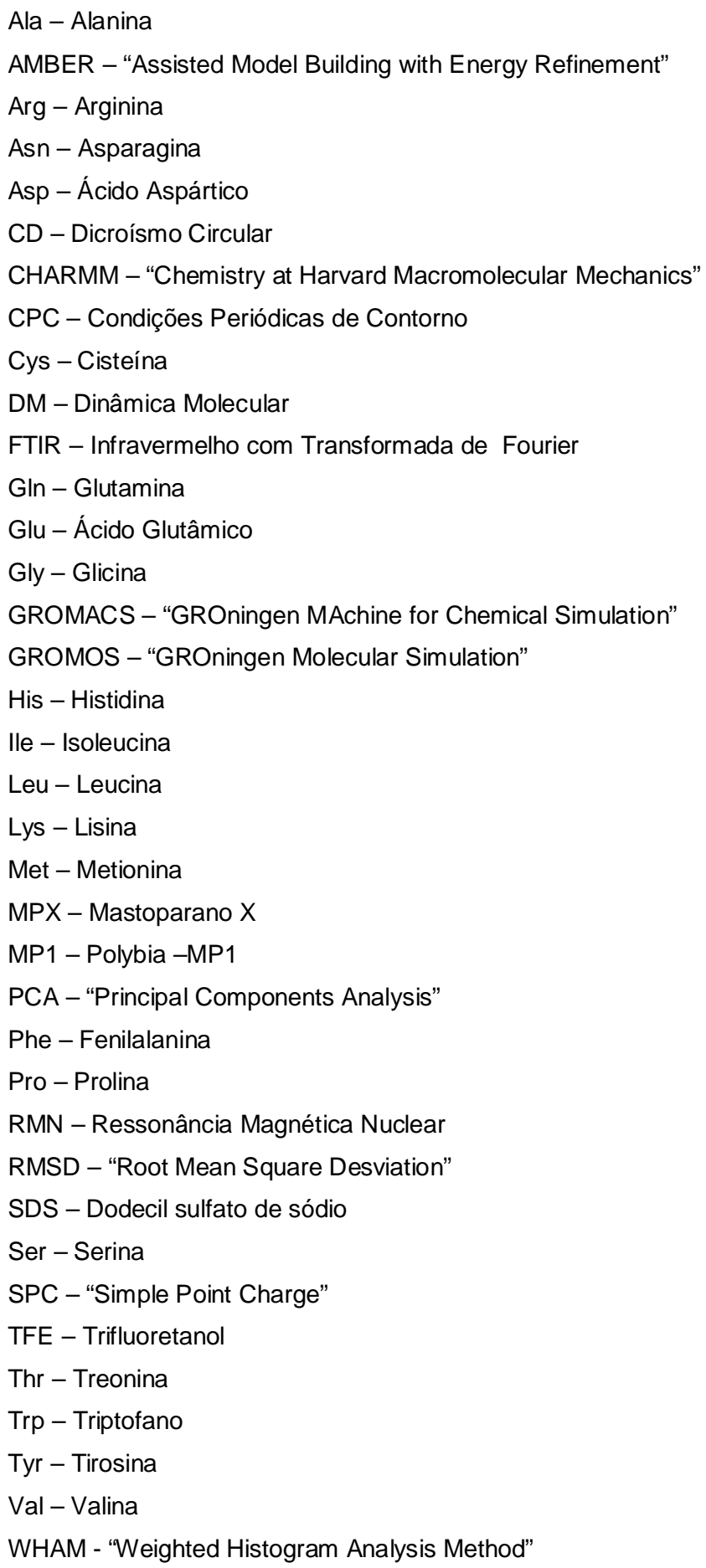




\section{SUMÁRIO}

\section{Capítulo 1. Introdução}

1.1 Peptídeos Antimicrobianos e seus Mecanismos de Ação com Membranas.............................1

1.2 Peptídeos Antimicrobianos Extraídos de Vespas................................................................

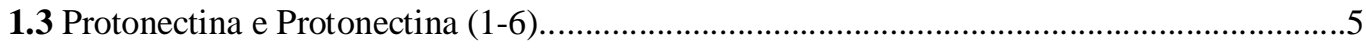

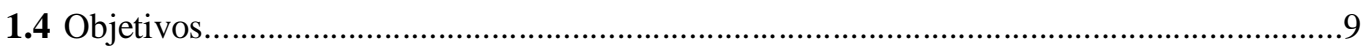

Capítulo 2. Métodos e Modelagem

2.1 Simulação por Dinâmica Molecular................................................................................10

2.2 Campo de Forças......................................................................................................

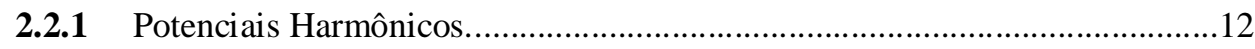

2.2.2 Potencial Torcional Próprio.........................................................................

2.2.3 Potencial de Lennard Jones..........................................................................14

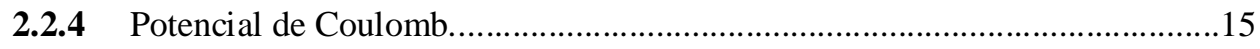

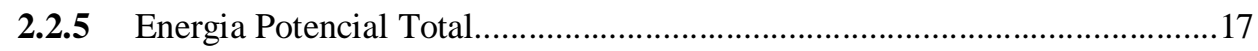

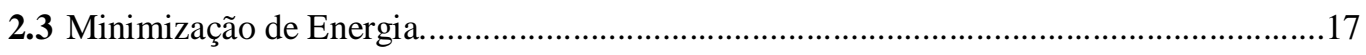

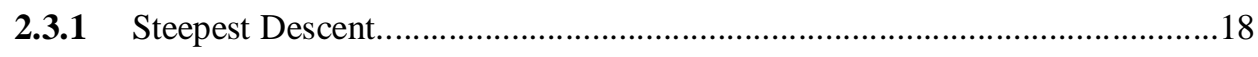

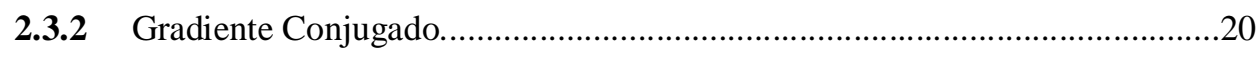

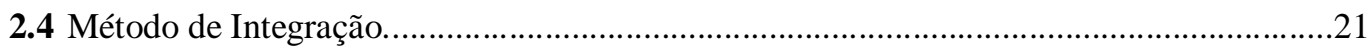

2.5 Técnicas e Modelos Utilizados na Simulação...................................................................22

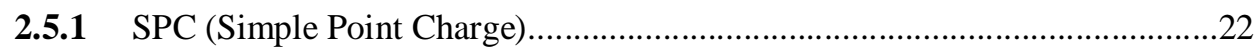

2.5.2 Condições Periódicas de Contorno (CPC)....................................................2

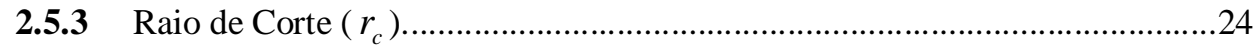

2.6 Parâmetros da simulação..........................................................................................24

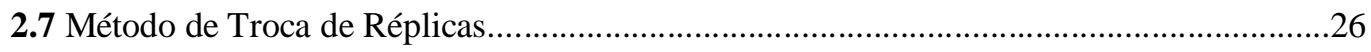




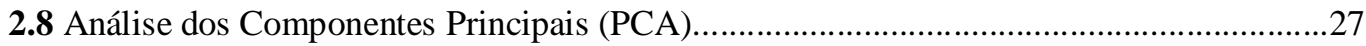

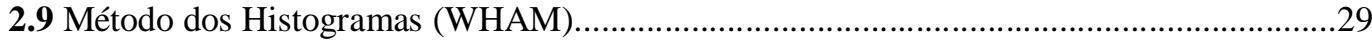

Capítulo 3. Estudo Conformacional da Protonectina Isolada em mistura água-TFE

3.1 Resultados da Dinâmica Molecular associada ao Método de Troca de Réplicas ................32

3.2 Resultados das Dinâmicas Moleculares de Equilíbrio...............................................................45

\section{Capítulo 4}

Resultados da Dinâmica de Equilíbrio da Protonectina associada com a Protonectina 1-6 .53

\section{Capítulo 5}

Conclusão

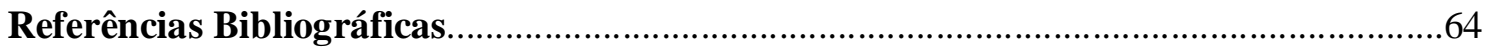

Apêndice A: Análise da energia potencial das simulações de equilíbrio................................68

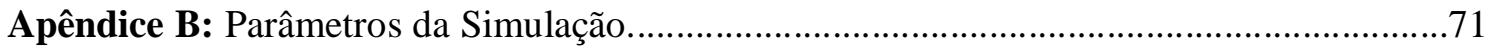




\section{Capítulo 1}

\section{INTRODUÇÃO}

\subsection{Peptídeos Antimicrobianos e seus Mecanismos de Ação em Membranas}

Muitos peptídeos antimicrobianos, compostos de até 50 resíduos de aminoácidos, têm sido descobertos em uma grande variedade de espécies de plantas, insetos e animais, constituindo o sistema de defesa dessas espécies contra microorganismos patogênicos. (Matsuzaki K., 2009).

Por exibirem um amplo espectro de atividade antimicrobiana (contra bactérias grampositivas e negativas, fungos e parasitas), especula-se a utilização destes peptídeos como possíveis novos antibióticos. Assim seus mecanismos de ação vêm sendo estudados usando sistemas modelos que mimetizam o ambiente de membrana, como por exemplo, arranjos de fosfolipídios de composição diversificada na forma de bicamadas, vesículas, micelas de SDS (sódiododecilsulfato) ou em soluções contendo co-solventes com propriedades hidrofóbicohidrofílicas, como por exemplo, soluções água - TFE (trifluoretanol) (Rocatano D., et al, 2002; Fioroni M., et al., 2002).

Técnicas como: microscopia, difração de raios-X, ressonância magnética nuclear (RMN), espectroscopias: de infravermelho com transformada de Fourier (FTIR), Raman, de fluorescência e de dicroísmo circular, permitem acessar aspectos ligeiramente diferentes dos mecanismos de ação e, embora, uma técnica individualmente não forneça o mapa completo do problema, no conjunto, elas evidenciam que tanto a composição como a estrutura são fundamentais para a atividade e especificidade da ação biológica dos peptídeos.

Algumas características dos peptídeos antimicrobianos, tais como, o tamanho, a sequiência, a carga, a conformação estrutural, a hidrofobicidade, a anfipaticidade e a amidação do C terminal, estão diretamente relacionadas com a sua atividade e especificidade, e estas têm sido utilizadas para caracterizar a susceptibilidade de microorganismos simples a estes peptídeos (dos Santos Cabrera et al., 2008 e dos Santos Cabrera et al., 2009). A presença de estrutura anfipática (distribuição dos resíduos de aminoácidos em duas regiões: hidrofóbica e hidrofílica) é uma característica importante para a adsorção, inserção e a translocação destes peptídeos através da bicamada lipídica das membranas (Hori Y., et al., 2001). A cationicidade 
dos peptídeos antimicrobianos contribui principalmente para seletividade celular, devido ao fato das superfícies de membranas apresentarem diferentes composições lipídicas. As membranas bacterianas apresentam bicamadas aniônicas enquanto que as bicamadas de eritrócitos são zwiteriônicas, alguns estudos mostram que peptídeos catiônicos com alta carga líquida são pouco seletivos. (Yeman e Yount, 2003; Dathe at al, 2001; Matsuzaki K., 2009).

A hidrofobicidade de um peptídeo é definida como a média de valores numéricos da hidrofobicidade por resíduo e é uma medida da habilidade de um peptídeo mover-se de uma fase aquosa para uma fase hidrofóbica, medindo assim seu grau de afinidade com as cadeias lipídicas (Yeaman e Yount, 2003). Muitos estudos mostram que o aumento da hidrofobicidade está associado com o aumento da permeabilização de bicamadas zwiteriônicas e/ou aniônicas, ou seja, aumento nas atividades hemolítica e antimicrobiana (Zhao H., 2003; dos Santos Cabrera et al., 2008). O Mastoparano X (MP-X) é um peptídeo cuja hidrofobicidade média é 0,009 e apresenta atividade hemolítica e antimicrobiana. No entanto o peptídeo Polybia MP-1, apesar de apresentar um alto grau de homologia se comparado ao MP-X (tabela 1.1.1), tem hidrofobicidade média igual a -0,108 e mostra-se seletivo em relação à bactérias (de Souza et al., 2005), este e outros trabalhos sugerem que quanto maior a hidrofobicidade média do peptídeo, menor é sua seletividade. Os cálculos de hidrofobicidade, abordados nesses trabalhos, foram realizados utilizando a tabela de consensus proposta por Eisemberg D. et al (1984), e ao observarmos os valores calculados para os diferentes tipos de resíduos é possível notar que mudanças na hidrofobicidade não podem ser associadas diretamente com mudanças na carga líquida de uma dada seqüência peptídica.

\begin{tabular}{|l|l|}
\hline \multicolumn{2}{|c|}{ TABELA 1.1.1: Seqüência Primária dos Peptídeos Mastoparano X e Polybia MP1 (Murata K. et al, 2006) } \\
\hline \multicolumn{1}{|c|}{ Peptídeo } & \multicolumn{1}{c|}{ Seqüência } \\
\hline Mastoparano X & Ile Asn Trp Lys Gln Ile Ala Ala Met Ala Lys Lys Leu Leu -NH $\mathrm{NH}_{2}$ \\
\hline Polybia MP-1 & Ile Asn Trp Leu Lys Leu Gly Lys Lys Val Ser Ala Ile Leu -NH $\mathrm{NH}_{2}$ \\
\hline
\end{tabular}

Broggio Costa, 2006 apresenta estudos de dinâmica molecular de peptídeos bioativos em misturas de água - TFE, cujas análises de solvatação indicam que a organização do solvente na região do peptídeo pode ser correlacionada com aspectos estruturais como ângulo polar e anfipaticidade que por sua vez servem de modelo numa tentativa de explicar o 
aumento ou diminuição de determinadas ações biológicas. Alguns estudos com MP-X e Polybia MP-1 exemplificam esse fato; análises de solvatação da cadeia principal do MP-X mostram que esta é preferencialmente solvatada por moléculas de TFE, protegendo-a do contato com as moléculas de água. Este fato favorece a manutenção de sua estrutura helicoidal, por preservar as ligações de hidrogênio intra-cadeia. No entanto, o Polybia MP-1 tem sua cadeia principal solvatada tanto por moléculas de água quanto de TFE e sua estrutura helicoidal é mantida pela interação eletrostática proporcionada pelo arranjo ideal dos resíduos polares e carregados. As moléculas de TFE e água proporcionam ao MP-X um ambiente organizado sugerindo uma possível explicação para a forma de interação com bicamadas zwiteriônicas. O Polybia MP-1 interage preferencialmente com membranas de bactérias, e isso pode ser relacionado com a ausência de organização do solvente em torno da cadeia peptídica e com a diminuição de sua carga líquida (dos Santos Cabrera et al., 2008).

Os mecanismos de ação dos peptídeos antimicrobianos envolvem etapas como a atração, o ancoramento e a inserção na membrana. Presume-se que a primeira etapa seja comandada pela atração eletrostática entre o peptídeo e os grupos carregados e/ou polares das membranas. Deve-se destacar que muitos peptídeos são desestruturados ou em conformação estendida em solução. O processo de aproximação para a membrana parece induzir uma conformação estruturada, altamente ordenada e quase sempre anfipática. A partir de um mínimo de concentração de moléculas de peptídeo sobre a superfície da membrana ocorre seu ancoramento adequado, com os aminoácidos carregados ou polares interagindo com os grupos carregados e/ou polares da membrana e os aminoácidos hidrofóbicos "enterrados" na membrana, ou seja, na sua fase hidrofóbica. (Matsuzaki et al., 1997; Dathe et al., 2001).

A permeabilização da membrana pode ocorrer através de três mecanismos (Mátyus E., et al, 2007): (1) Poro-barril (figura 1.1.1a), modelo no qual a face hidrofóbica do peptídeo anfipático interage com a região das caudas alquílicas dos fosfolipídios da membrana, e a face hidrofílica do peptídeo forma um poro aquoso. Neste modelo, as cabeças dos fosfolipídios da membrana permanecem localizadas na interface água-membrana. Uma condição necessária deste mecanismo é que os peptídeos sejam suficientemente longos para que eles possam atravessar o núcleo hidrofóbico da membrana (Yang et al., 2001); (2) Poro toroidal (figura 1.1.1b), neste modelo o peptídeo se agrega à bicamada e interage com as cabeças dos fosfolipídios da membrana. Esta interação provoca uma curvatura na membrana que dá origem à cavidade chamada de poro toroidal (Tossi et al., 2000); (3) Mecanismo de Carpet, 
modelo no qual as moléculas de peptídeo se acumulam paralelamente à superfície da membrana causando uma desarrumação em seu interior, a superfície hidrofílica dos peptídeos interage com as cabeças dos grupos fosfolipídicos da membrana e a região hidrofóbica dos peptídeos se orienta para o interior hidrofóbico da membrana. Este é um mecanismo que não necessita que o peptídeo apresente uma estrutura específica, assim como também não é necessário a formação de um canal transmembrânico estruturado (Oren \& Shai, 1998).

A inserção do peptídeo na membrana pode ser acompanhada de uma série de eventos que contribuem para a desativação celular, tais como: despolarização da membrana, vazamento de metabólitos essenciais e perda de composições específicas, devido às perturbações nos fosfolipídios (Matsuzaki et al., 1996).

O domínio da compreensão molecular, destes mecanismos abre perspectivas otimistas para a projeção e síntese dos futuros peptídeos farmacêuticos antimicrobianos.

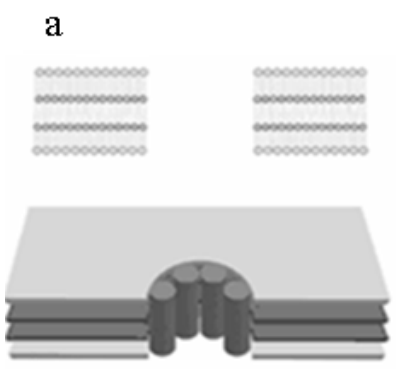

Poro-barril

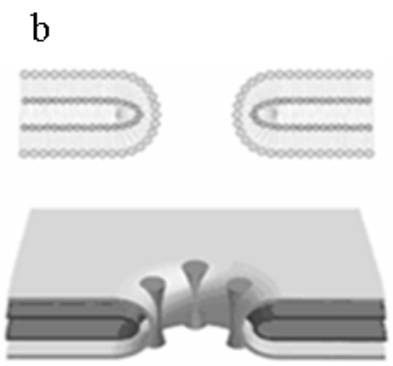

Poro toroidal

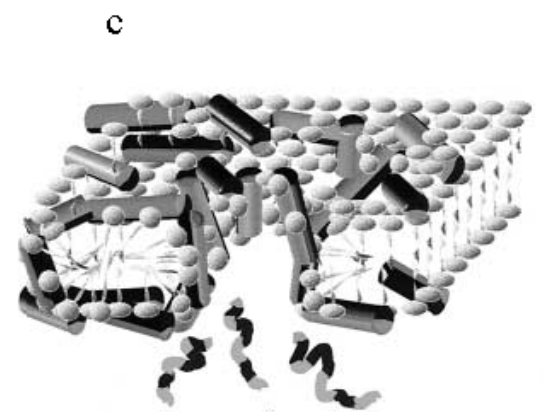

FIGURA 1.1.1: Representação dos mecanismos de ação com membranas dos peptídeos antimicrobianos. A) mecanismo de Poro-barril. B) mecanismo de Poro toroidal. C) Mecanismo de Carpet. (http://www.ruf.rice.edu/ hwhuang/toroidalModelVsBarrelStave.html)

\subsection{Peptídeos Antimicrobianos Extraídos do Veneno de Vespas}

Hymenoptera é uma ordem da classe dos insetos composta por mais de duzentas mil espécies de abelhas, vespas e formigas (Vetter and Visscher, 1998). Os venenos das picadas destes insetos contêm numerosas substâncias biologicamente ativas, que são identificadas como aminas (histamina, serotonina, dopamina, e norepinefrina), enzimas (fosfolipase, hialuromidase, histidina decarboxilase), e polipeptídeos como melitina, apamina, além de outros peptídeos biologicamente ativos (Argiolas and Pisano, 1983). 
Diversos peptídeos bioativos foram isolados do veneno de vespas. Tais peptídeos são classificados em famílias, segundo suas atividades biológicas e estruturas moleculares, por exemplo: (1) os mastoparanos, que são tetradecapeptídeos que apresentam de 10 a 14 resíduos de aminoácidos hidrofóbicos e de 2 a 4 resíduos de lisinas, geralmente nas posições 4, 5, 11 e 12, em suas sequiências primárias (de Souza et al, 2005). (2) os peptídeos catiônicos que contém de 12 a 50 resíduos de aminoácidos, e carga líquida de +2 a +7 , apresentam excesso de resíduos de aminoácidos básicos e mais de $50 \%$ de sua seqüência primária é constituída de resíduos hidrofóbicos (Mendes M. A. et al. 2004). (3) peptídeos quimiotáticos, são tridecapeptídeos, apresentam muitos resíduos de aminoácidos hidrofóbicos e um único resíduo básico (Mendes M. A. et al. 2004).

\subsection{Protonectina e Protonectina 1-6}

O veneno de alguns insetos, tais como: vespas e abelhas contêm vários peptídeos farmacologicamente ativos. Podem ser citados como exemplo peptídeos degranuladores de mastócito (mastoparanos) (de Souza et al, 2005), peptídeos hemolíticos e peptídeos quimiotáticos (Murata K., et al., 2006).

Recentemente um par de peptídeos quimiotáticos foi extraído do veneno da vespa social Agelaia pallipes pallipes (Mendes M. A. et al., 2004). Depois de isolado e purificado ele foi caracterizado quanto a sua seqüência primária, atividade biológica e físicoquímicamente por espectroscopia de dicroísmo circular (CD) (Saidemberg N. B. B., 2007). Os peptídeos são denominados Protonectina e Protonectina 1-6 e suas seqüências primarias estão apresentadas na tabela 1.3.1.

\begin{tabular}{||l|l||}
\hline \multicolumn{2}{|c||}{ TABELA 1.3.1: Sequiência primária da Protonectina e Protonectina 1-6. } \\
Em azul: resíduos carregados, em verde: resíduos polares, em preto: resíduos hidrofóbicos \\
\hline \hline Protonectina & Ile - Leu - Gly - Thr - Ile - Leu - Gly - Leu -Leu - Lys - Gly - Leu - $\mathrm{NH}_{2}$ \\
\hline \hline Protonectina 1-6 & Ile - Leu - Gly - Thr - Ile - Leu - $\mathrm{NH}_{2}$ \\
\hline
\end{tabular}

Deve-se observar que:

- A seqüência primária da Protonectina 1-6 corresponde aos seis primeiros aminoácidos da Protonectina; 
- A Protonectina é composta de aminoácidos hidrofóbicos, com uma única lisina presente enquanto na Protonectina 1-6 todos os aminoácidos são hidrofóbicos;

- A Protonectina apresenta 3 resíduos de glicina que estão na posição i - i+4 (3, 7 e 11), dispostas simetricamente ao longo da cadeia contendo dois resíduos hidrofóbicos e um polar entre elas.

- Ambos têm o C-terminal amidado.

Os resultados das análises estruturais e funcionais (Saidemberg N. B. B., 2007) revelam que a Protonectina deve ser um peptídeo estruturado anfifílico, enquanto que Protonectina (16) é muito pequeno para assumir estrutura secundária anfifílica. Os dados exibidos na Tabela 1.3.2 mostram que Protonectina apresenta atividade hemolítica, degranuladora de mastócito e de liberação de LDH e atividade quimiotática. Enquanto que a Protonectina (1-6) apresenta atividade quimiotática elevada se comparada com a Protonectina e nenhuma atividade hemolítica, degranuladora de mastócito e de liberação de LDH. A mistura de ambos os peptídeos na proporção molar 1:1, resultou na potencialização de aproximadamente $87 \%$ da atividade hemolítica, 35\% da atividade de degranulação de mastócitos e $60 \%$ de liberação de LDH (característica de interação com membranas) se comparada com a protonectina isolada. Ao mesmo tempo, essa mistura causou uma diminuição significativa na atividade quimiotática, quando comparada com os resultados de cada peptídeo individualmente.

TABELA 1.3.2: Propriedades biológicas da Protonectina, Protonectina 1-6 e associação de ambos os peptideos na proporção estequimétrica 1:1 de acordo com Saidemberg N. B. B., 2007.

\begin{tabular}{|l|c|c|c|}
\hline & Protonectina & Protonectina 1-6 & $\begin{array}{c}\text { Protonectina/Protonectina 1-6 } \\
\text { (proporção 1:1) }\end{array}$ \\
\hline Peso molecular & $1209 \mathrm{Da}$ & $628 \mathrm{Da}$ & ----- \\
\hline Atividade hemolitica & $\mathrm{ED}_{50}=9,9.10^{-7} \mathrm{M}$ & Não apresenta & $\mathrm{ED}_{50}=5,3.10^{-7} \mathrm{M}$ \\
\hline Degranulação de mastócito & $\mathrm{ED}_{50}=4,6.10^{-6} \mathrm{M}$ & Não apresenta & $\mathrm{ED}_{50}=3,4.10^{-7} \mathrm{M}$ \\
\hline LDH & $\sim 40 \%$ & Não apresenta & $\sim 100 \%$ \\
\hline Quimiotaxia & $8.10^{4}$ celulas $/ \mathrm{mL}$ & $10.10^{4}$ celulas $/ \mathrm{mL}$ & $5.10^{4}$ celulas $/ \mathrm{mL}$ \\
\hline
\end{tabular}

Do ponto de vista estrutural, ensaios por dicroismo circular na presença de TFE $40 \%$ (v/v), indicam que cerca de 21,3\% dos resíduos da Protonectina participam de conformação em hélice- $\alpha$ direita e na mistura de ambos os peptídeos na proporção estequiométrica de 1:1, o 
percentual de residuos em $\alpha$-hélice direita sobe para cerca de $24,4 \%$, mais detalhes são apresentados na tabela 1.3.3*.

TABELA 1.3.3: Conteúdo helicoidal da Protonectina e mistura (1:1) da Protonectina e Protonectina 1-6 calculado de acordo com o modelo de dois estados em diferentes meios (Rohl e Baldwin, 1998) *. E de acordo com o CDPro program **.

$(\mathrm{H}(\mathrm{d})$ e $\mathrm{H}(\mathrm{e})$ referem-se à hélice direita ( $\alpha$-hélice) e distorcida, respectivamente e desordenadas refere-se a estruturas não ordenadas).

\begin{tabular}{|c|c|c|c|c|c|c|c|}
\hline & \multicolumn{2}{|c|}{ \% a-hélice * } & & \multicolumn{4}{|c|}{ \% CDPro structures ** } \\
\hline & \multirow[t]{2}{*}{ Protonectina } & \multirow[t]{2}{*}{$\begin{array}{c}\text { Mistura dos } \\
\text { peptídeos (1:1) }\end{array}$} & & \multicolumn{2}{|c|}{ Protonectina } & \multicolumn{2}{|c|}{$\begin{array}{c}\text { Mistura dos } \\
\text { peptídeos (1:1) }\end{array}$} \\
\hline & & & & TFE & SDS & TFE & SDS \\
\hline Água & $\mathrm{rc}$ & $\mathrm{rc}$ & H (d) & 21,3 & 18,8 & 24,4 & 21,5 \\
\hline SDS $165 \mu \mathrm{M}$ & $\mathrm{rc}$ & $\mathrm{rc}$ & H (e) & 16,7 & 16,4 & 18,5 & 16,6 \\
\hline SDS 8 mM & 22,8 & 27,5 & Voltas & 20,1 & 19,6 & 17,7 & 18,6 \\
\hline TFE $40 \%$ & 29,0 & 32,8 & desordenadas & 26,7 & 26,7 & 25,0 & 26,8 \\
\hline
\end{tabular}

Dados não publicados cedidos via comunicação oral pelo Laboratório de Biopolimeros situado no Departamento de Física deste Instituto.

Os resultados sugerem que a interação entre os dois peptideos é fator responsável pelos efeitos potencializadores e/ou inibidores obtidos da análise funcional e estrutural. E ainda, levaram os pesquisadores (Saidemberg N. B. B., 2007) à conjecturar que quando associados entre si, estes peptídeos formariam uma estrutura supramolecular estável ao nível de estrutura secundária, a ponto de passar a apresentar fenômenos de interação com membranas das células animais, como por exemplo, hemólise e ruptura de membranas de mastócitos.

A hidrofobicidade média por resíduo destes peptídeos foi calculada utilizando a escala consensus (Eisemberg D., et al., 1984). Daí verificou-se que a Protonectina apresenta a hidrofobicidade média de 0,276, a Protonectina 1-6 0,417 e a associação de ambos os peptídeos na proporção de 1:1 apresentou valor de hidrofobicidade de 0,323. Valores que podem ser considerados altos se comparados com os do MP-X e do Polybia MP-1, apresentados na seção 1.1 ..

Análogos quimiotáticos da Protonectina foram identificados por outros pesquisadores. Alguns deles, acompanhados de sua sequência primária, são apresentados na tabela 1.3.4.. 
Embora sejam oriundos de espécies distintas, todos apresentam carga líquida +2 , o N-terminal amidado e alta hidrofobicidade.

\begin{tabular}{|c|c|c|c|}
\hline \multicolumn{4}{|c|}{$\begin{array}{l}\text { TABELA 1.3.4.: Análogos da Protonectina. } \\
\text { Em destaque: diferenças nas sequências primárias dos peptídeos }\end{array}$} \\
\hline Peptídeo & Vespa & Sequência primária & Hidrofobicidade \\
\hline Orancis-Protonectin* & Orancistrocerus drewseni drewseni & ILGIITSLLKŚL-NH ${ }_{2}$ & 0,223 \\
\hline Polibya-CP** & Polybia paulista & ILGTILGLLKSL-NH ${ }_{2}$ & 0,241 \\
\hline Polistes-Protonectin $* * *$ & Polistes rothneyi iwatai & ILSALLGLLKSL-NH ${ }_{2}$ & 0,225 \\
\hline Protonectina & Agelaia palipes palipes & ILGTILGLLKGL-NH $_{2}$ & 0,276 \\
\hline
\end{tabular}

Orancis-Protonectin é um dodecapeptídeo, sequecialmente diferente da Protonectina em dois aspectos: (1) os resíduos de treonina (posição 4) e leucina (posição 5) presentes na protonectina, aparecem com suas posições invertidas na Orancis-Protonectin. (2) os resíduos de glicina das posições 7 e 11 da Protonectina são substitídos por serinas na OrancisProtonectin. Dados biológicos revelam que a atividade hemolítica da Orancis-Protonectin é mais potente do que o de certos mastoparanos, de forma que ela apresenta $\sim 80 \%$ de hemólise

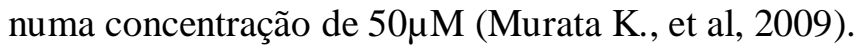

Do ponto de vista biológico, estudos revelam que Polybia-CP (que possui 90\% de similaridade com a protonectina) apresenta atividade de degranulação de mastócito (52\%), liberação de LDH (50\%) e hemolítica ( 78\%) para concentrações de peptídeo da ordem de $10^{-4} \mathrm{M}$. Entretanto, esta é uma concentração muito alta para se especular alguma ação importante sob condições fisiológicas. Ele apresenta atividade antimicrobiana contra bactérias gram positivas e contrariamente à protonectina, parece não interagir, em condições fisiológicas, com membranas zwiteriônicas (Souza B. M., et al., 2005).

Outro representante da família dos quimiotáticos é a Polistes-Protonectin; ela difere da protonectina pelo fato de que em sua estrutura primária, os residuos de glicina das posições 3 e 11 são substituídos por serinas, o resíduo de treonina da posição 4 (Protonectina) é substituído por uma alanina (Polistes-Protonectin) e no lugar da leucina (posição 5) é encontrada uma isoleucina na polistes-protonectin. Além das diferenças estruturais, estudos (Murata K., et al., 2006) revelam que a atividade hemolítica da polistes-protonectin é mais 
potente que a da protonectina, de forma que, a polistes-protonectin apresenta $97 \%$ de atividade hemolítica à concentração de $50 \mu \mathrm{M}$.

Estes resultados abrem novas perpectivas para o estudo da relação atividade/estrutura dessas classes de peptídeos bioativos.

\subsection{Objetivos}

Tendo em vista os resultados dos ensaios funcionais da Protonectina isolada e em associação com a Protonectina 1-6 este trabalho tem como objetivo:

1. Investigar através do uso de dinâmica molecular associada ao método de troca de réplicas o espaço conformacional da Protonectina.

2. Realizar simulação de equilíbrio da Protonectina associada com a Protonectina 16 a fim de compreender, do ponto de vista molecular, as interações envolvidas na associação destes peptídeos.

3. Verificar como o posicionamento e o tipo de resíduo na seqüência podem influenciar a estabilidade estrutural destes peptídeos em misturas de TFE e água.

4. Investigar as diferenças na hidrofobicidade do peptídeo e na organização das moléculas de solvente para a protonectina isolada e para a associação da protonectina com a protonectina 1-6, na tentativa de justificar as diferenças no espectro de atividades.

5. Buscar outras explicações a nível atômico, que ajudem a compreender as diferenças entre as atividades biológicas observadas para estes peptídeos. 


\section{Capítulo 2}

\section{MÉTODOS E MODELAGEM}

\subsection{Simulação por Dinâmica Molecular}

Simulação por Dinâmica Molecular (DM) é uma técnica que calcula os movimentos de moléculas individuais em modelos de sólidos, líquidos ou gases. A principal idéia desta técnica é descrever como as posições, as velocidades e as orientações dos átomos que constituem o sistema em estudo variam com o tempo.

Um tratamento quântico de todo e qualquer átomo que constitui o sistema em estudo resultaria nas melhores previsões para a estrutura e propriedades físicas do conjunto, no entanto, este tratamento se torna impraticável computacionalmente quando o sistema molecular é complexo e possui muitos átomos.

Por isso assume-se que os movimentos das partículas que compõem o sistema obedecem às leis da mecânica clássica, sendo os átomos e moléculas tratados como cargas pontuais ou esferas de Van der Waals que interagem entre si através das forças que atuam sobre cada partícula e que são calculadas através da primeira derivada do potencial em relação às posições. A cada passo de simulação as forças são reavaliadas, e devido ao elevado número de átomos, a função potencial deve ser complexa o suficiente para uma análise realística do sistema em estudo e ao mesmo tempo simples, para que os cálculos sejam efetuados com rapidez e baixo custo computacional.

Como condição inicial para uma simulação por DM deve-se ter um arquivo com as respectivas posições de cada átomo do sistema abordado. Conhecendo as coordenadas das

posições $\left(\overrightarrow{x_{i}}\right)$ e dos momentos $\left(\overrightarrow{p_{i}}\right)$ que especificam cada átomo, pode-se escrever a Hamiltoniana como sendo a soma das energias cinética e potencial do sistema:

$$
H=\sum_{i=1}^{N} \frac{\left(\overrightarrow{p_{i}}\right)^{2}}{2 m_{i}}+V\left\{\left(\overrightarrow{x_{i}}\right)\right\},
$$

onde $N$ é o número total de átomos que constituem o sistema e $m_{i}$ é a massa de cada átomo.

A partir da equação 2.1.1 é possível obter as equações de movimento de Newton que, uma vez resolvidas, fornecem a evolução temporal de cada partícula do sistema: 


$$
\begin{gathered}
\frac{\partial H}{\partial \overrightarrow{x_{i}}}=-\frac{\partial V\left\{\left(\overrightarrow{x_{i}}\right)\right\}}{\partial \overrightarrow{x_{i}}}=\vec{F}_{i}=m_{i} \frac{d \overrightarrow{v_{i}}}{d t} \\
\frac{\partial H}{\partial \overrightarrow{p_{i}}}=\frac{\overrightarrow{p_{i}}}{m_{i}}=\overrightarrow{v_{i}}=\frac{d \overrightarrow{x_{i}}}{d t}
\end{gathered}
$$

Estas equações são resolvidas para pequenos intervalos de tempo. $\vec{F}_{i}$ é a força sobre o átomo $i$ e $t$ é o tempo.

Durante as simulações por dinâmica molecular as coordenadas de posição e velocidade das partículas são gravadas em intervalos de tempo regular. Estas coordenadas, como função do tempo, representam a trajetória do sistema, que posteriormente são utilizadas com o pacote GROMACS (Lindahal et al., 2001) para analisar o sistema.

\subsection{Campo de Forças}

Para a determinação das equações de movimento é essencial conhecer a energia potencial total do sistema como função das posições dos átomos ou grupos de átomos que constituem o mesmo.

Como já ressaltado, a melhor maneira de se obter este resultado seria através da resolução quanto-mecânica que determina a energia de menor estado dos elétrons do sistema, contudo, este método é muito custoso computacionalmente. Por isso, são utilizadas funções potenciais clássicas para descrever a energia potencial total do sistema em estudo, que têm seus parâmetros ajustados a partir de dados experimentais e de cálculos quânticos. O conjunto de termos que descreve a energia potencial do sistema em estudo é chamado de campo de forças molecular (Brooks III et al, 1998).

Existem diversos tipos de campo de forças com funções potenciais e parametrizações específicas. Como exemplo, podemos citar o AMBER (Weiner S J et al., 1996), o CHARMM (Brooks B. R., et al, 1983) e o GROMOS (van Gunsteren et al., 1987).

Todas as simulações realizadas neste trabalho utilizaram o campo de forças do GROMOS96 (van Gunsteren et al., 1996), com representação de átomo unido para os hidrogênios não polares. A função de energia potencial é descrita por três termos de potenciais harmônicos e um torcional, todos correspondentes às interações entre átomos quimicamente ligados, e dois termos para o potencial de átomos não ligados, que são os 
átomos separados por três ou mais ligações químicas. A seguir, cada um destes termos é discutido com mais detalhes.

\subsubsection{Potenciais Harmônicos}

A natureza vibracional das ligações covalentes permite que o comprimento e o tamanho dos ângulos da ligação apresentem flutuações em torno de suas posições de equilíbrio. Tal fato permite que o sistema seja associado a um sistema massa-mola, tornando possível caracterizar essas vibrações através de termos clássicos para a energia potencial.

O potencial de ligação entre dois átomos covalentemente ligados é descrito em termos do comprimento de equilíbrio da ligação covalente $\left(b_{0}\right)$ e da constante elástica da ligação ( $K_{b}$ ) que é obtida através de estudos espectroscópicos

$$
V_{b}=\frac{1}{2} K_{b}\left(b-b_{0}\right)^{2}
$$

De maneira análoga pode-se representar o potencial angular, responsável por manter o ângulo entre três átomos covalentemente ligados

$$
V_{\theta}=\frac{1}{2} K_{\theta}\left(\theta-\theta_{0}\right)^{2}
$$

onde $\theta$ é o ângulo entre as ligações num certo instante, $\theta_{0}$ é o ângulo de equilíbrio entre as ligações e $K_{\theta}$ é a constante de força da ligação, ou seja, a constante que determina o quão difícil é a distorção do ângulo.

Há ainda um termo de potencial harmônico, o potencial torcional impróprio, que é necessário para manter a estrutura tridimensional do conjunto dos átomos centrados no átomo de carbono, garantindo assim a estrutura tetraédrica dos átomos de carbono com hibridação $s p^{3}$.

Isto é necessário porque somente os átomos de hidrogênio ligados á átomos eletronegativos (oxigênio, nitrogênio) são considerados explicitamente, os átomos de hidrogênio ligados a átomos de carbono são unidos a eles, ou seja, são considerados como um único átomo, essa simplificação é feita com o objetivo de diminuir o custo computacional. 


$$
V_{\xi}=\frac{1}{2} K_{\xi}\left(\xi-\xi_{0}\right)^{2}
$$

A equação acima representa o termo de potencial torcional impróprio, no qual $\xi$ é o ângulo entre os planos definidos por i-j-k e j-k-1 (figura 2.2.1.1), $\xi_{0}$ é o ângulo de equilíbrio e $K_{\xi}$ é a constante elástica de restituição do ângulo de equilíbrio.

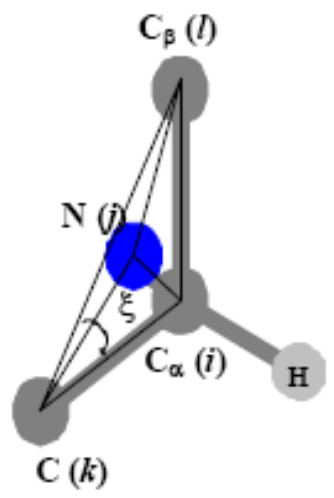

FIGURA 2.2.1.1: Estrutura tetraédrica do carbono $\alpha$. $\xi$ é o ângulo entre i-j-k e j-k-1

\subsubsection{Potencial Torcional Próprio}

O potencial torcional próprio é uma maneira de representar a rotação em torno da ligação covalente entre dois átomos.

Os ângulos de torção podem ser utilizados para especificar a conformação estrutural da cadeia principal do peptídeo. As principais modificações destes ângulos ocorrem em torno das ligações $\mathrm{N}-\mathrm{C} \alpha(\Phi)$ e $\mathrm{C} \alpha-\mathrm{C}(\Psi)$.

A periodicidade deste potencial é dada por uma função co-seno na qual $n$ é o número de mínimos para a torção de uma ligação química, $\delta$ a diferença de fase, que pode adotar valores $0^{\circ}$ ou $180^{\circ}$, $\varphi$ é o ângulo diedral para a ligação central na série dos quatro átomos e $K_{\varphi}$ é a constante que define a barreira de torção (Van Gunsteren et al., 1987)

$$
V_{\varphi}=K_{\varphi}[1+\cos (n \varphi-\delta)]
$$




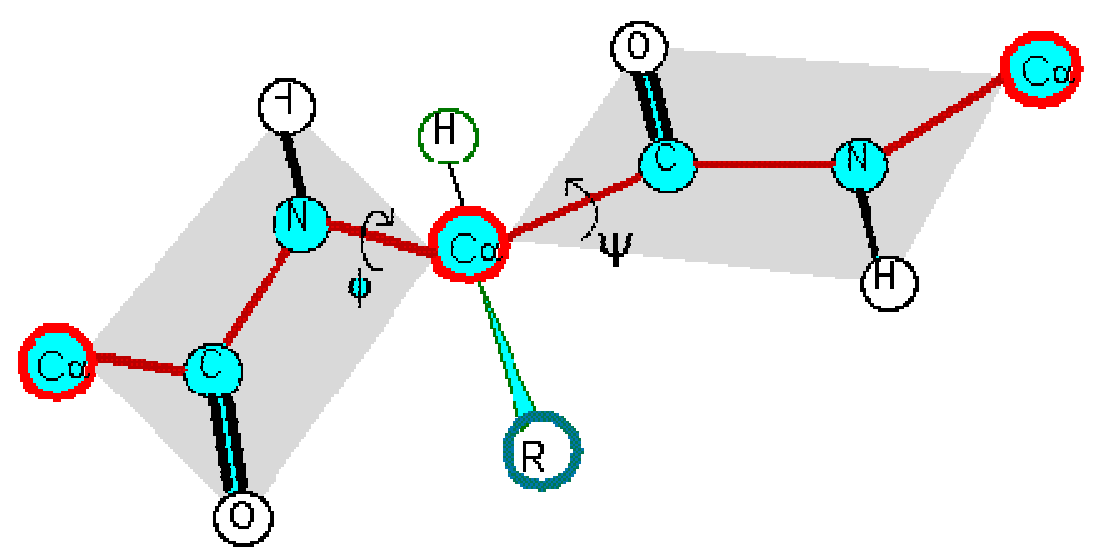

FIGURA 2.2.2.1: Rotação em torno da ligação covalente entre dois átomos.

\subsubsection{Potencial de Lennard Jones}

A interação atrativa total entre as moléculas que não formam ligações por hidrogênio é a soma das contribuições das interações dipolo-dipolo, dipolo-dipolo induzido, e de dispersão, que são formadas pelos deslocamentos oscilantes das nuvens eletrônicas. Esta interação varia com o inverso da sexta potência da distância de separação $r$ e pode ser escrita da seguinte maneira:

$$
V=\frac{A}{r^{6}},
$$

onde $A$ é um coeficiente que depende da natureza das moléculas.

Termos repulsivos tornam-se importantes e passam a dominar as forças quando a distancia entre um par de átomos é da ordem de $r_{i}+r_{j}$, onde $r_{i}$ e $r_{j}$ são os raios da esfera de

Van der Waals correspondentes aos átomos $i$ e $j$ respectivamente. Á medida que as moléculas ficam muito próximas o termo repulsivo impede a interpenetração das nuvens eletrônicas respeitando o principio de exclusão de Pauli que pró́be que pares de elétrons com os mesmos números quânticos ocupem a mesma região no espaço.

Uma descrição completa da repulsão devido a interpenetração das nuvens eletrônicas requer um tratamento quântico. A forma usualmente utilizada para representar esse efeito nas interações é pela introdução de um termo empírico de potencial do tipo:

$$
V=\frac{B}{r^{n}} .
$$


Tipicamente, $n$ é fixado em 12, de modo que para distancias pequenas de separação, o termo de repulsão domina o termo de atração, pois $\frac{1}{r^{12}}>>\frac{1}{r^{6}}$.

A soma dos termos de interação atrativa e repulsiva é denominada potencial de Lennard Jones (Atkins, 2003)

$$
V=4 \varepsilon\left\{\left(\frac{\sigma}{r}\right)^{12}-\left(\frac{\sigma}{r}\right)^{6}\right\},
$$

onde $\varepsilon$ é a profundidade do poço e o parâmetro $\sigma$ é o diâmetro de Lennard Jones, separação para o qual $V=0$. Ambas dependem da natureza dos átomos envolvidos.

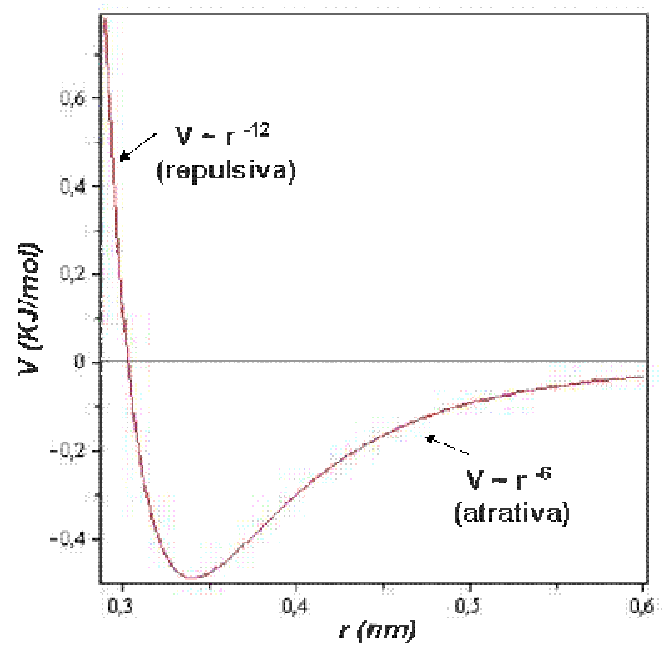

FIGURA 2.2.3.1: Representação do Potencial de Lennard Jones para o Carbono.

\subsubsection{Potencial de Coulomb}

O potencial de Coulomb é usado para descrever a interação eletrostática entre átomos não ligados quimicamente. É um potencial de longo alcance, proporcional ao inverso da distância, que surge devido à distribuição eletrônica dos átomos. É descrito da forma:

$$
V=\sum_{i} \sum_{j>i} \frac{q_{i} q_{j}}{4 \pi \varepsilon_{m} r_{i, j}}
$$

Nessa expressão $q_{i}$ e $q_{j}$ são as cargas parciais, que representam a distribuição eletrônica dos átomos, $r$ é a distancia de separação entre elas e $\varepsilon_{m}$ é a permissividade do 
meio no qual se encontram as cargas. Esta permissividade normalmente é escrita como múltiplo da permissividade do vácuo, $\varepsilon_{0}$, a qual é igual a $8.854 .10^{-12} \mathrm{~J}^{-1} \mathrm{C}^{2} \mathrm{~m}^{-1}$ (SI). Dessa forma $\varepsilon_{m}=\varepsilon_{r} \varepsilon_{0}$, onde $\varepsilon_{r}$ é a permissividade relativa ou constante dielétrica.

O efeito do meio pode ser muito grande: para a água $\varepsilon_{r}=78$, assim a energia potencial das duas cargas separadas pelo volume de água é reduzida em quase duas ordens de grandeza comparada ao valor que teria se as cargas estivessem no vácuo.

Nas simulações por Dinâmica Molecular, o raio de corte, é utilizado como alternativa para diminuir o custo computacional. As energias de Coulomb e Lennard Jones são calculadas explicitamente somente para os átomos que se encontram no interior de uma esfera com raio igual ao raio de corte. Os átomos que se encontram fora desta região recebem um tratamento diferenciado. Uma maneira de tratar o meio externo ao raio de corte é considerar que ele seja homogêneo e atribuir a ele uma constante dielétrica $\varepsilon_{r f}$, este método é chamado de Campo de Reação e a interação de Coulomb se torna:

$$
V_{r f}=f \frac{q_{i} q_{j}}{r_{i j}}\left[1+\frac{\varepsilon_{r f}-1}{2 \varepsilon_{r f}+1} \frac{r_{i j}{ }^{3}}{r_{c}{ }^{3}}\right]-f \frac{q_{i} q_{j}}{r_{c}} \frac{3 \varepsilon_{r f}}{2 \varepsilon_{r f}+1} .
$$

$\mathrm{Na}$ equação $i$ e $j$ são quaisquer dois átomos que se encontram dentro do raio de corte. Nela, o potencial torna-se zero à medida que se aproxima do raio de corte, o gráfico que representa a equação está apresentado na Figura 2.2.4.1.

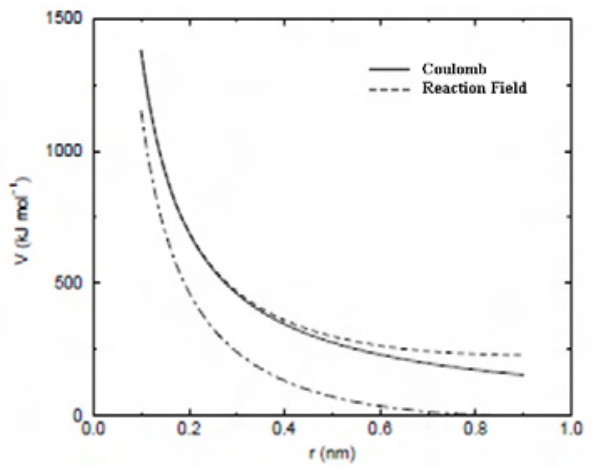

FIGURA 2.2.4.1: A interação de Coulomb (para partículas com cargas de mesmo sinal) com e sem reaction field. No último caso o valor utilizado para $\mathcal{E}_{r f}$ foi 78 , o raio de corte $r_{c}$ foi $0.9 \mathrm{~nm}$. A linha pontotracejada é a mesma que a tracejada exceto por uma constante. 


\subsubsection{Energia Potencial Total}

A função de energia potencial total para o sistema em estudo é simplesmente a soma de todos os termos de potencial apresentados nas seções anteriores. Esta função descreve a interação entre os átomos ligados e os átomos não ligados, e é descrita na equação 2.2.5.1, na qual os quatro primeiros termos descrevem as interações entre os átomos ligados e os termos seguintes, potencial de Lennard Jones e Coulomb com reaction field respectivamente, tratam das interações dos átomos não ligados

$$
\begin{aligned}
V\left(\left\{\vec{x}_{i}\right\}\right) & =\sum_{n=1}^{N b} \frac{1}{2} K_{b n}\left(b_{n}-b_{0}\right)^{2}+\sum_{n=1}^{N \theta} \frac{1}{2} K_{\theta n}\left(\theta_{n}-\theta_{0}\right)^{2}+\sum_{n=1}^{N \xi} \frac{1}{2} K_{\xi_{n}}\left(\xi_{n}-\xi_{0}\right)^{2}+ \\
& +\sum_{n=1}^{N \varphi} K_{\varphi n}\left[1+\cos \left(n_{n} \varphi_{n}-\delta_{n}\right)\right]+\sum_{i<j}^{N}\left(\frac{C_{12}(i, j)}{r_{i j}^{12}}-\frac{C_{6}(i, j)}{r_{i j}}\right)+ \\
& \sum_{i<j}^{N}\left(f \frac{q_{i} q_{j}}{r_{i j}}\left[1+\frac{\varepsilon_{r f}-1}{2 \varepsilon_{r f}+1} \frac{r_{i j}^{3}}{r_{c}^{3}}\right]-f \frac{q_{i} q_{j}}{r_{c}} \frac{3 \varepsilon_{r f}}{2 \varepsilon_{r f}+1}\right) .
\end{aligned}
$$

Na equação acima se tem $N$ como sendo o número total de átomos, $\vec{x}_{i}$ para $i=1,2$, $3, \ldots, N$ são os vetores correspondentes às posições dos átomos, $N_{b}$ o número de ligações químicas, $N_{\theta}$ o número de átomos entre os pares de ligações consecutivas, $N_{\xi}$ o número de ângulos diedrais impróprios e $N_{\varphi}$ o número de ângulos diedrais próprios. $C_{12}(i, j)$ e $C_{6}(i, j)$ são constantes que substituem os parâmetros $\varepsilon$ e $\sigma$ na equação 2.2.3.3.

No presente trabalho utilizou-se o GROMOS/96 como campo de forças e o grupo de parâmetros utilizado foi o 43 a1.

\subsection{Minimização de Energia}

A função de energia potencial total de um sistema molecular (equação 2.2.5.1) é muito complexa. Ela possui um ponto de mínimo global e vários pontos de mínimos locais, nos 
quais todas as derivadas da função de energia potencial são zero e todas as segundas derivadas são positivas.

Devido ao elevado número de graus de liberdade das macromoléculas biológicas, uma exploração completa da superfície multidimensional de energia é praticamente impossível. Uma maneira de explorar esta superfície se dá pelo método de minimização da energia potencial deste sistema, que consiste basicamente em caminhar pela superfície em estudo na direção em que a energia decresce, de maneira que o sistema é levado para um ponto de mínimo local. Este é um passo muito importante nas simulações de dinâmica molecular, pois a minimização de energia pode ajustar as posições atômicas e com isso relaxar os conflitos estéricos, nos ângulos entre as ligações e nos contatos de Van der Waals.

O processo de otimização da energia através de algoritmos de otimização clássicos consiste na comparação do valor da função energia potencial em dois vetores posição consecutivos. O vetor posição para o passo seguinte é dado por:

$$
\vec{x}_{t+1}=\vec{x}_{t}+\Delta \vec{x}_{t}
$$

Na equação 2.3.1, $t$ é o passo em análise e $\Delta \vec{x}_{t}$ é, inicialmente, uma perturbação aleatória nas coordenadas que estão sendo otimizadas. Há varias maneiras de se determinar o

incremento $\Delta \vec{x}_{t}$, uma delas é o emprego da primeira derivada da função de energia potencial. Uma outra maneira, mais sofisticada, emprega também a segunda derivada da função de energia potencial, que melhora bastante a taxa de convergência.

A simulação descrita neste trabalho, que é realizada através da utilização do GROMACS e tem suas energias potenciais previamente minimizadas por dois algoritmos de otimização: O Steepest Descent (seção 2.3.1) e o Gradiente Conjugado (seção 2.3.2).

\subsubsection{Steepest Descent}

O Steepest Descent é um método de primeira derivada que converge vagarosamente para as proximidades do mínimo local, sendo muito eficaz nas situações em que o vetor posição se encontra muito longe do mínimo de energia.

Como já mencionado anteriormente, a força resultante sobre um átomo $i$ é obtida pelo gradiente da função da energia potencial total (equação 2.2.5.1) em $i$. 
Neste método o incremento $\Delta \overrightarrow{x_{t}}$ nas coordenadas de um átomo $i$ é dado pela direção e sentido da força resultante sobre este átomo

$$
\vec{x}_{t+1}=\vec{x}_{t}+\Delta \vec{x}_{t}
$$

na qual,

$$
\Delta \vec{x}_{t}=K_{n}\left(\vec{F}_{i} /\left|\vec{F}_{i}\right|\right)
$$

Nessa expressão, $\vec{F}_{i} /\left|\vec{F}_{i}\right|$ é o vetor unitário na direção e sentido da força resultante sobre o átomo $i . K_{n}$ é um parâmetro de ajuste do passo, usado para acelerar a minimização de forma que se no passo $n$ o potencial total $V_{n}\left(\left\{\overrightarrow{x_{i}}\right\}\right)$ dado pela equação 2.2.5.1 diminuir em relação a $V_{n-1}\left(\left\{\overrightarrow{x_{i}}\right\}\right)$, no passo posterior $K_{n}$ é aumentado, fazendo-se:

$$
K_{n+1}=K_{n} C,
$$

nesta equação $C$ é uma constante positiva e maior que um.

Se $V_{n}\left(\left\{\overrightarrow{x_{i}}\right\}\right)$ aumentar em relação à $V_{n-1}\left(\left\{\vec{x}_{i}\right\}\right)$ significa que o sistema está se afastando do mínimo local, $K_{n}$ pode estar muito grande fazendo com que o sistema tenha passado pelo mínimo local e tenha começado escalar o outro lado do poço de potencial, por isso o passo posterior $K_{n+1}$ deve ser diminuído, para tal utiliza-se a equação 2.3.1.3 agora com a constante multiplicativa $C$ sendo novamente positiva, porém menor que um.

A cada passo é verificada a diferença entre $V_{n}\left(\left\{\overrightarrow{x_{i}}\right\}\right)$ e $V_{n-1}\left(\left\{\overrightarrow{x_{i}}\right\}\right)$. Se esta diferença for menor que certo valor $\Delta V$ estipulado, o processo de minimização pelo algoritmo Steepest Descent chega ao fim.

Um valor de $\Delta V=10^{-2} \mathrm{Kcal} / \mathrm{mol}$ elimina, na maioria dos sistemas moleculares, as deformações em ligações e ângulos e conflitos estéricos, o que é importante na preparação de um sistema que será submetido à simulação por dinâmica molecular, pois durante a dinâmica, as conversões entre energia potencial e cinética são constantes, de maneira que um sistema com energia potencial elevada apresentará temperaturas irreais em seus primeiros passos de simulação e isso pode tornar o sistema instável, exigindo passos de integração cada vez menores até que uma distribuição adequada de energia seja obtida. 


\subsubsection{Gradiente Conjugado}

Gradiente Conjugado é um método considerado de segunda ordem, apresenta, nas vizinhanças do mínimo, convergência mais rápida que o Steepest Descent (seção 2.3.1) e pode ser aplicado em sistemas que apresentam restrições de posição e ângulo para seus átomos.

O método dos Gradientes Conjugados utiliza para a determinação do passo seguinte o valor do gradiente no ponto atual e o valor do gradiente obtido no passo anterior. Neste método $\Delta \vec{x}_{t}$ é dado por:

$$
\Delta \vec{x}_{t}=K_{n} \vec{\delta}_{i, n}
$$

Na qual,

$$
\overrightarrow{\boldsymbol{\delta}}_{i, n}=\left(\vec{F}_{i, n}|| \vec{F}_{i, n} \mid\right)+\overrightarrow{\boldsymbol{\delta}}_{i, n-1}\left(\left|F_{i, n}\right|^{2} /\left|F_{i, n-1}\right|^{2}\right)
$$

$K_{n}$ é um parâmetro ajustável a cada passo.

As equações 2.3.2.1 e 2.3.2.2 garantem que a direção do gradiente no novo ponto será sempre ortogonal à direção do ponto anterior, o que é vantajoso, pois desta forma, o método do Gradiente Conjugado determina um caminho mais direto ao fundo do poço de potencial, evitando o retorno sobre os caminhos já percorridos.

Os métodos Steepest Descent e Gradiente Conjugado podem ser usados em conjunto, sendo o Steepest Descent usado nos passos iniciais, pois quando se está muito longe do mínimo, este algoritmo se mostra mais efetivo e rápido, no entanto quando se está perto de atingir o ponto de mínimo o método do Gradiente Conjugado é muito mais rápido e preciso. Por isso podem-se conjugar os dois métodos utilizando primeiramente o Steepest Descent com um critério de convergência relativamente fraco e posteriormente utiliza-se o método do Gradiente Conjugado para o refinamento final.

\subsection{Método de Integração}

Na simulação computacional por dinâmica molecular a integração das equações do movimento usa a mais simples das técnicas numéricas, o método de "Summed Verlet" (Verlet L., 1967), que é um método de baixa ordem e possui excelentes propriedades de conservação 
de energia (em sua forma, o método gera coordenadas que são precisas até a terceira ordem em $\Delta t$ ), e do ponto de vista da conservação de energia, quando potenciais do tipo de Lennard Jones estão envolvidos, tende a ser considerado melhor que outros métodos de ordem superior.

Assim, como em outros métodos de integração numérica, no algoritmo de "summed" Verlet resolvem-se as equações de movimento de Newton para cada átomo em cada passo de integração. O processo que mais consome tempo computacional é o calculo das forças para a obtenção das acelerações, este tempo depende de quão complexa é a função para a energia potencial.

A fórmula de Verlet é obtida a partir da expansão de Taylor da coordenada variável, em torno de $\left(t+\frac{\Delta t}{2}\right)$ e $\left(t-\frac{\Delta t}{2}\right)$

$$
\vec{v}_{i}\left(t+\frac{\Delta t}{2}\right)=\vec{v}_{i}(t)+\frac{d \vec{v}_{i}(t)}{d t}\left(\frac{\Delta t}{2}\right)+\frac{d^{2} \vec{v}_{i}(t)}{d t^{2}}\left(\frac{\Delta t}{2}\right)^{2} \frac{1}{2 !} .
$$

Fazendo a expansão de $\vec{v}_{i}\left(t-\frac{\Delta t}{2}\right)$ e subtraindo-a da equação 2.4.1, tem-se:

$$
\vec{v}_{i}\left(t+\frac{\Delta t}{2}\right)=\vec{v}_{i}\left(t-\frac{\Delta t}{2}\right)+\frac{d \vec{v}_{i}(t)}{d t} \Delta t .
$$

Sabe-se que $\frac{d \vec{v}_{i}(t)}{d t}=\frac{\vec{F}_{i}\left(\vec{x}_{i}\right)}{m_{i}}$, e fazendo a devida substituição na equação 2.4.2:

$$
\vec{v}_{i}\left(t+\frac{\Delta t}{2}\right)=\vec{v}_{i}\left(t-\frac{\Delta t}{2}\right)+\frac{\vec{F}_{i}\left(\vec{x}_{i}\right)}{m_{i}} \Delta t
$$

Fazendo a expansão de $\vec{x}_{i}(t+\Delta t)$

$$
\vec{x}_{i}(t+\Delta t)=\vec{x}_{i}(t)+\frac{d \vec{x}_{i}(t)}{d t} \Delta t+\frac{d^{2} \vec{x}_{i}(t)}{d t^{2}} \frac{(\Delta t)^{2}}{2 !} .
$$

E substituindo a equação 2.4.1 na equação 2.4.4 e desconsiderando os termos de ordem superior, tem-se:

$$
\vec{x}_{i}(t+\Delta t)=\vec{x}_{i}(t)+\vec{v}_{i}\left(t+\frac{\Delta t}{2}\right) \Delta t
$$

As equações 2.4 .3 e 2.4.5 são calculadas de forma iterativa. No entanto, as velocidades e as posições não podem ser calculadas ao mesmo tempo, como conseqüência, as energias 
cinética e potencial não podem ser calculadas no mesmo instante. Esse problema pode ser contornado calculando-se a velocidade no instante $t$ como a média das velocidades nos instantes $\left(t+\frac{\Delta t}{2}\right) \mathrm{e}\left(t-\frac{\Delta t}{2}\right)$.

\subsection{Técnicas e Modelos Utilizados na Simulação}

Para que uma simulação de dinâmica molecular seja bem sucedida é necessária a utilização de técnicas que tornem o sistema em estudo o mais próximo possível de um sistema real. Por exemplo, nesta simulação, utiliza-se o SPC como modelo de água (seção 2.5.1), o conceito de Condições Periódicas de Contorno é considerado (seção 2.5.2) para minimizar os efeitos de fronteira entre os átomos e a caixa durante a simulação, e outra técnica, também utilizada neste trabalho é o conceito de Raio de Corte (seção 2.5.3), o qual limita as interações de Van der Waals entre os átomos não ligados.

\subsubsection{SPC (Simple Point Charge)}

Para efetuar cálculos das interações entre moléculas de água no estado liquido, é necessário um modelo de molécula de água individual que possa informar onde as cargas residem.

$\mathrm{Na}$ simulação por dinâmica molecular abordada neste trabalho, o modelo de água considerado é o SPC (Berendsen H. J. C., 1981), que é um modelo muito simples no qual a molécula de água é representada por três centros pontuais de carga concentrada, com predominância de carga positiva sobre os átomos de hidrogênio e predominância de carga negativa sobre os átomos de oxigênio.

\subsubsection{Condições Periódicas de Contorno (CPC)}

Uma simulação eficaz deve incorporar todas as características do sistema de interesse. O objetivo de realizar uma simulação é entender o comportamento de sistemas reais, os quais possuem da ordem de $10^{23}-10^{25}$ partículas. Nestes sistemas o efeito da interação das partículas com as paredes do recipiente é desprezível. 
A limitação nas velocidades de processamento tem restringindo o tamanho dos sistemas a $10^{3}$ a $10^{5}$ partículas. Para esses sistemas, a fração de partículas que interagem com as paredes do recipiente é significativa e o comportamento destes é influenciado pelos efeitos de superfície.

Para minimizar os efeitos de superfície utiliza-se o que é conhecido como "Condições Periódicas de Contorno", que consiste basicamente em replicar várias vezes o sistema em estudo de forma que não haja espaços não preenchidos entre as junções, ou seja, a caixa original é transladada nas três direções espaciais, formando uma rede (figura 2.5.2.1).

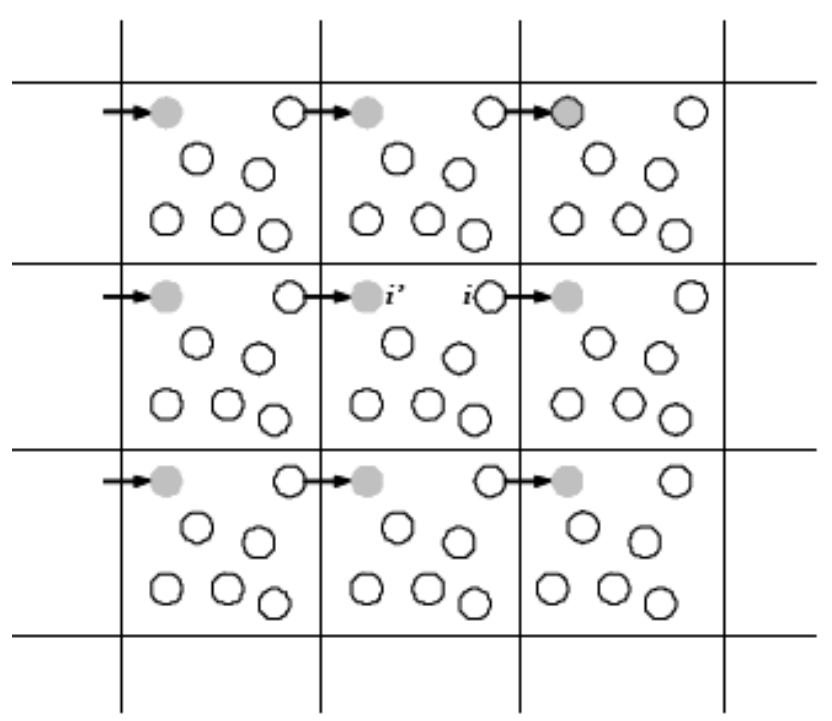

FIGURA 2.5.2.1: Esquema bidimensional das Condições de Contorno Periódicas.

Nesta técnica, durante a simulação, quando um átomo se move na caixa original suas réplicas se movem igualmente nas caixas imagens. Se certo átomo $(i)$ sai da caixa original, uma de suas imagens ( $i^{\prime}$ ) entra pela face oposta, mantendo assim constante o número de átomos na caixa original.

\subsubsection{Raio de Corte $\left(r_{c}\right)$}

A utilização das condições periódicas de contorno torna necessário o uso de uma outra técnica chamada de raio de corte. 
A utilização das CPC aumenta significativamente a quantidade de átomos que constituem o sistema em estudo, consequentemente há um aumento no custo computacional para o cálculo das interações entre os átomos que constituem o sistema, devido ao grande número de termos que haveria para que este cálculo fosse feito. Para diminuir este custo, usualmente, defini-se uma região na qual, essas interações são calculadas. Essa região é delimitada por uma esfera de raio $r_{c}$, denominado raio de corte, que em geral é utilizado no cálculo das interações Coulombianas e de Van der Waals. Fora dessa região utiliza-se um tratamento especial para esses cálculos, no caso deste trabalho o tratamento é feito utilizando o Reaction Field (Lins R. D. and Röthlisberger U., 2006).

De acordo com Allen and Tildesley (1987), $r_{c}$ deve ser definido da seguinte maneira $r_{c} \leq \mathrm{L} / 2$, na qual L é o menor comprimento lateral da caixa, assim é evitado a interação do soluto (proteína, peptídeo, carboidrato) com as suas imagens.

\subsection{Parâmetros da simulação}

Os aspectos conformacionais de diversos peptídeos bioativos (EMP-AF, MP-1 e Anoplin) em misturas água-TFE (70/30) foram discutidos a partir de trajetórias obtidas por dinâmica molecular (dos Santos Cabrera et al 2007, 2008). Estes resultados revelam que o caráter anfipático (hidrofóbico/hidrofílico) do TFE é fundamental para a manutenção de estruturas helicoidais nestes peptídeos. Dessa forma, os estudos por dinâmica molecular em misturas água-TFE, associados aos dados experimentais existentes e a modelos conceituais, têm proporcionado compreensão no nível molecular e a possibilidade de sugerir interpretações e modelos para os dados experimentais.

Para todos os sistemas estudados neste trabalho, caixas de simulação contendo o(s) peptídeo(s), cerca de 400 moléculas de TFE e cerca de 3450 moléculas de água e íons cloro em quantidade suficiente para neutralizar as caixas, foram construídas e termalizadas.

Para o estudo da protonectina isolada foram utilizados dois conjuntos de simulações: (1) dinâmica molecular associada ao método de troca de réplicas (seção 3.1), com dezesseis trajetórias de aproximadamente 60 ns no intervalo de temperaturas de 287 a 342 K. (2) Seis simulações por dinâmica molecular de equilíbrio (seção 3.2) na temperatura de $300 \mathrm{~K}$, partindo de conformações distintas obtidas com o método de troca de réplicas. 
A associação da protonectina com a protonectina $1-6$ foi estudada a partir de uma simulação de equilíbrio produzida no ensemble (n, p, T) na temperatura de 300K e pressão de $1 \mathrm{~atm}$. As conformações iniciais (figura 2.6.1) para peptídeos desta simulação foram obtidas das simulações realizadas utilizando o método de troca de réplicas.
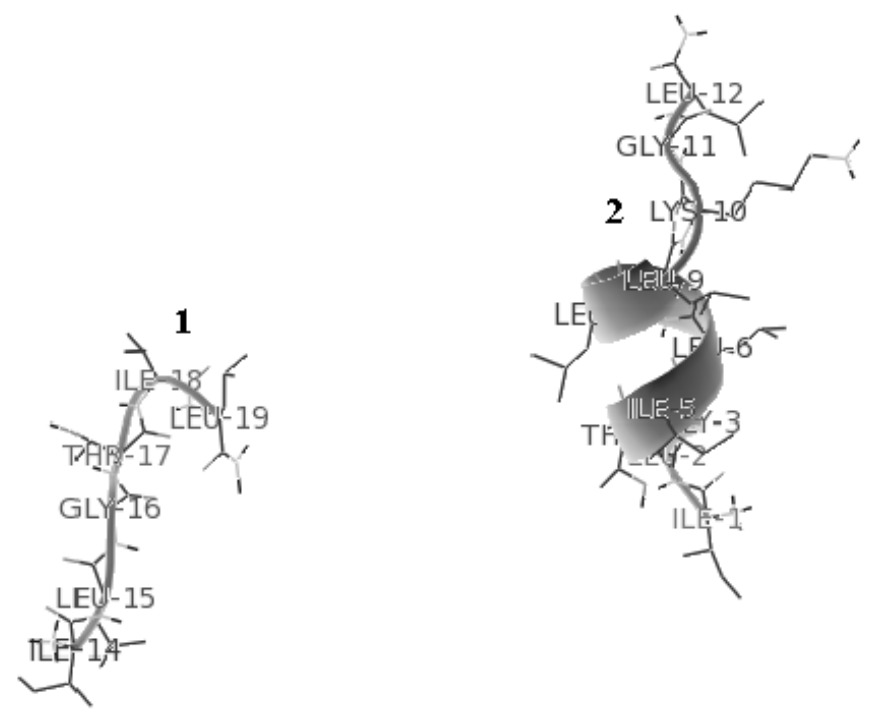

FIGURA 2.6.1: Conformação de partida da simulação da Protonectina associada com a Protonectina 16. (1) conformação da Protonectina 1-6 editada através da conformação obtida no instante de 51ns da réplica de temperatura 306K. (2) conformação da Protonectina obtida no instante de 31ns da réplica de temperatura 299K.

Em todas as simulações a temperatura e pressão de cada caixa foram mantidas constantes através da utilização das técnicas de acoplamento de Berendsen (Berendsen H. J. C., et al., 1984) As interações eletrostáticas de longa distância foram tratadas usando o Reaction Field (Lins R. D. and Röthlisberger U., 2006), com a constante dielétrica do meio igual a 60.

Em todos os sistemas o N-terminal do peptídeo em estudo foi tratado como um grupo carregado positivamente $\left(\mathrm{NH}_{3}{ }^{+}\right)$e o C-terminal foi amidado. $\mathrm{O}$ campo de forças utilizado nos cálculos de DM é o GROMOS 96 (van Gunsteren, 1996). O modelo de água utilizado foi o SPC “Simple Point Charge” (Berendsen H. J. C., 1981), e para as moléculas de TFE o modelo proposto por Fioroni (Fioroni M. et al., 2000). A otimização do sistema foi realizada com alternação de passos de gradiente conjugado e steepest descent. Uma dinâmica de restrição de posição de $1 \mathrm{~ns}$ foi rodada para permitir a relaxação dos íons e do solvente. O passo de 
integração para as equações de movimento foi de 2 fs. Condições periódicas de contorno foram impostas nas simulações com um raio de corte de $1,4 \mathrm{~nm}$ e a lista de visinhos foi atualizada a cada 5 passos de simulação. Os algoritmos LINCS (Hess B., et al., 1997) e SETTLE (Miyamoto S., et al., 1992) foram usados para simular todos os comprimentos das ligações químicas existentes nos sistemas e a geometria apropriada da água, respectivamente. Os cálculos de DM e as análises das trajetórias foram realizados utilizando as facilidades do pacote GROMACS (Lindahal E., et al., 2001) e o método dos histogramas (WHAM).

\subsection{Método de Troca de Réplicas}

Dinâmica molecular com troca de réplicas (Sugita Y. et. al., 1999; Rhee Y. M. et. al., 2003) é um método usado para aumentar a freqüência de acesso às conformações do sistema, especialmente se estas conformações estiverem separadas por barreiras de energia, pois o método evita que o sistema fique preso em mínimos locais.

Neste método, $M$ copias (réplicas) do sistema, que não interagem entre si, são simuladas de forma mais ou menos independente usando Dinâmica Molecular ou Monte Carlo, em diferentes temperaturas. Numa dada freqüência durante a simulação, trocas entre os pares de réplicas são realizadas obedecendo a uma probabilidade de transição específica. Considere dois sistemas vizinhos $i$ e $j$, com temperaturas $T_{i}$ e $T_{j}$ respectivamente, este método permite que estes sistemas mudem de configuração de tal maneira que o sistema $i$ muda para a temperatura $T_{j}$, e o sistema $j$ para a temperatura $T_{i}$, de acordo com a probabilidade de transição:

$$
P(i \leftrightarrow j)=\min \left(1, \exp \left[\left(\frac{1}{K_{B} T_{i}}-\frac{1}{K_{B} T_{j}}\right)(U i-U j)\right]\right),
$$

onde $U_{i}$ e $U_{j}$ são as energias potencias instantâneas das réplicas $i$ e $j$ antes da troca. São testadas apenas as trocas de réplicas entre temperaturas vizinhas devido ao fato da razão de aceitação diminuir exponencialmente com a diferença entre as duas temperaturas $(T)$ (Sugita Y. et. al., 1999).

Após a troca, as velocidades dos átomos do sistema são recalculadas a partir do reescalonamento de seus momentos: 


$$
\begin{gathered}
p_{j}=\sqrt{\frac{T_{i}}{T_{j}} p_{i}} \\
p_{i}=\sqrt{\frac{T_{j}}{T_{i}} p_{j}}
\end{gathered}
$$

A tentativa de troca com todos pares possíveis em um passo não é permitida. Se, por um instante, as réplicas 1 e 2 trocarem, a chance de troca para as réplicas 2 e 3 não depende apenas das energias delas, mas também da energia da réplica 1. No GROMACS isto é resolvido tentando permutar todos os pares 'ímpares' em tentativas 'ímpares' e todos os pares 'pares' em tentativas 'pares'. Se tivermos quatro réplicas: 0, 1, 2 e 3, ordenados por temperatura e tentarmos trocas a cada 1000 passos de dinâmica molecular (caso deste trabalho), os pares 0-1 e 2-3 serão examinados a cada 1000, 3000 etc. e o par 1-2 a cada 2000, 4000 etc.

\subsection{Análise dos Componentes Principais (PCA)}

Uma trajetória de dinâmica molecular contém os movimentos, e, portanto as correlações de todos os graus de liberdade do sistema em estudo. Para se obter informações mais precisas sobre cada grau de liberdade do sistema é necessário descorrelacionar tais dados. Um método bastante utilizado para este feito é denominado análises dos componentes principais (PCA).

Neste método, é realizada uma análise estatística da trajetória (posições x, y e z de cada átomo) obtida na simulação de dinâmica molecular. Como se trata de um espaço tridimensional, os dados das posições estão correlacionados. Assim, a covariância desses dados é útil para a obtenção de uma medida que descreve como as variações das médias de cada dimensão estão correlacionadas.

onde $x_{i}$ e $y_{i}$ são os valores das posições x e y de cada um dos $\mathrm{N}$ átomos do sistema e $\bar{x}$ e $\bar{y}$ são as médias nas dimensões $\mathrm{x}$ e $\mathrm{y}$, respectivamente.

A covariância é sempre medida em duas dimensões, então se o conjunto de dados a ser trabalhado possui três dimensões pode-se medir a covariância entre as dimensões xy, xz, e yz. 
Uma maneira útil para obter todos os possíveis valores de covariância entre todas as dimensões é calculá-los e colocá-los em uma matriz, chamada de matriz de covariância (Lindsay, 2002):

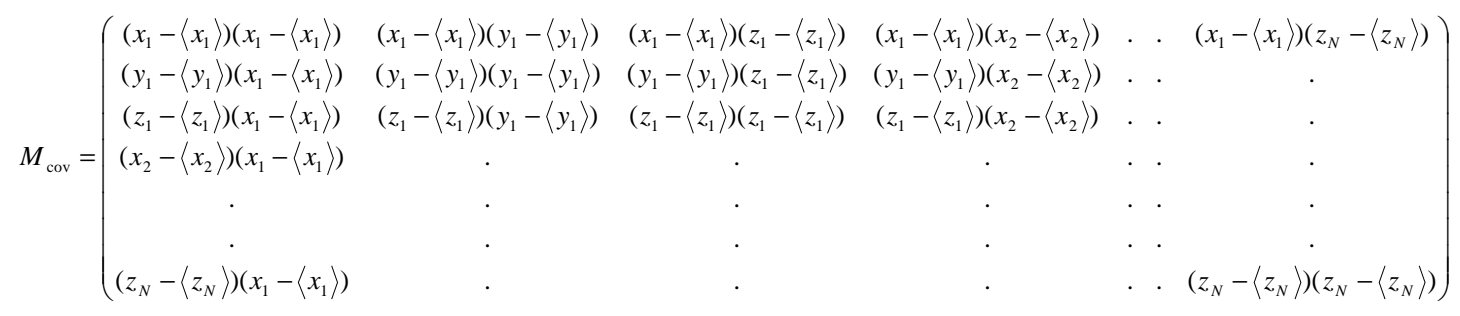

No método de análise do PCA aplicado nas simulações computacionais, a matriz de covariância (2.8.1) tem dimensão $3 \mathrm{~N}$ x $3 \mathrm{~N}$. A matriz da equação 2.8 .1 é calculada para cada frame da simulação.

O próximo passo é resolver o determinante da matriz resultante da diferença entre uma matriz unitária dos autovalores e a matriz de covariância (equação 2.8.2 e 2.8.3), Daí pode-se obter os autovalores correspondentes ao conjunto de dados que estão em análise.

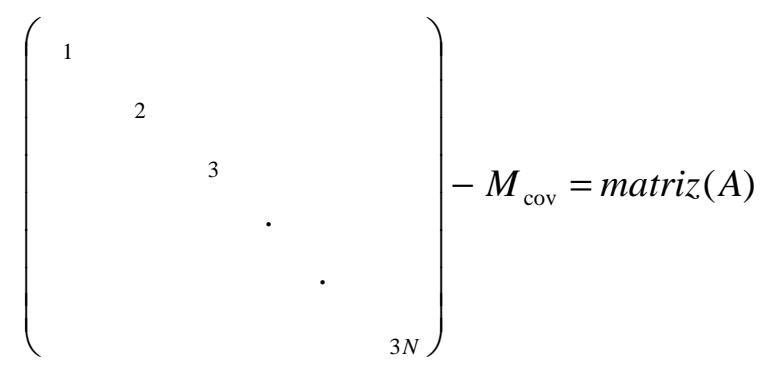

$$
\text { Determinante } A=0 \text { (zero) }
$$

Da relação acima se obtém um conjunto de sistemas que ao serem resolvidos fornecem os autovalores $(\lambda)$.

Tendo os autovalores, é possível calcular os autovetores: 


$$
M_{\mathrm{cov}} \cdot\left(\begin{array}{c}
v_{1} \\
v_{2} \\
v_{3} \\
\cdot \\
\cdot \\
v_{3 N}
\end{array}\right)=\lambda \cdot\left(\begin{array}{c}
v_{1} \\
v_{2} \\
v_{3} \\
\cdot \\
\cdot \\
v_{3 N}
\end{array}\right)
$$

A equação 2.8.4 é resolvida para cada autovalor obtido e o conjunto de autovetores resultantes é organizado em matrizes.

O resultado desses cálculos é fornecido pelo GROMACS como função do tempo de simulação.

Usualmente, a maioria das flutuações posicionais está concentrada em movimentos correlatos num subespaço de poucos graus de liberdade, enquanto que os outros não têm uma representação significativa. Por isso, o próximo passo é organizar os autovalores em ordem decrescente, de forma que o primeiro autovalor corresponda ao maior desvio da posição média, o segundo tem flutuação menor e assim por diante até que a partir de algum autovalor (entre o $5^{\circ}$ e $\circ 10^{\circ}$ ) essas flutuações tendam a zerar na trajetória. A projeção da trajetória na direção destes autovalores nos dá as componentes principais.

A componente principal é um parâmetro que pode ser utilizada juntamente com o método dos histogramas para obter a superfície de energia livre.

\subsection{Método dos Histogramas (WHAM)}

Vários métodos têm sido usados para calcular as mudanças na energia livre entre moléculas que interagem entre si e investigar as estabilidades relativas de diferentes estados conformacionais de moléculas. Tais cálculos são especialmente importantes para o entendimento entre as relações estrutura-função nas interações biomoleculares, promovendo a base para a modelagem de novas drogas (Kumar S, 1992). O método dos histogramas consiste em determinar a densidade de estados a partir de vários histogramas, coletados em diferentes temperaturas. O programa que implementa o método de análise dos histogramas ponderados (Kumar, et al. 1995) em uma e duas dimensões é o WHAM. Ele é um código livre e aberto e pode ser encontrado em (http://dasher.wustl.edu/alan/). As idéias básicas do método estão descritas abaixo. 
A probabilidade $P(E)$ de gerarmos um estado com energia $E$ é dada por:

$$
P(E)=\frac{\Omega(E) e^{-\beta E}}{Z}, \quad Z=\sum_{E} \Omega(E) e^{-\beta E}
$$

onde $\Omega(E)$ é a densidade de estados com energia $E$, que é a grandeza a ser determinada. Uma estimativa para a probabilidade $P(E)$ pode ser obtida através dos dados de uma simulação na qual se armazena o histograma de energias $N(E)$ num total de $n$ medidas da energia $E$. Assim,

$$
P(E)=\frac{N(E)}{n}
$$

Considere $\mathrm{R}$ simulações feitas em diferentes temperaturas. A simulação $i$ é realizada na temperatura $T_{i}=1 / \beta_{i}$. Uma estimativa da densidade de estados, oriunda da simulação $i$ é

$$
\Omega_{i}(E)=\frac{N_{i}(E)}{n_{i}} \frac{Z_{i}}{e^{-\beta_{i} E}}
$$

Um cálculo preciso da densidade de estados, que independesse da temperatura, poderia ser obtido, se fosse possível realizar número extremamente grande de simulações, feitas na temperatura $T_{i}$, mas que varresse todo o domínio de energias relevantes do sistema. Tomando a média dos histogramas nas diferentes simulações seria possível obter

$$
\Omega(E)=\frac{\overline{N_{i}(E)}}{n_{i}} \frac{Z_{i}}{e^{-\beta_{i} E}}
$$

Obviamente, esse número de simulações é proibitivo, o que torna $\overline{N_{i}(E)}$ uma grandeza desconhecida . Então, a estratégia a seguir consiste em realizar um número R, relativamente modesto, de simulações em diferentes temperaturas, que cubram o domínio de energias relevantes para a descrição do sistema. Agora o objetivo é calcular uma média ponderada das $\mathrm{R}$ estimativas da densidade de estados, obtidas por (2.9.3). Ou seja, obter os pesos $w_{i}$, que permitam calcular a média ponderada abaixo:

$$
\Omega(E)=\frac{\sum_{i=1}^{R} w_{i} \Omega_{i}(E)}{\sum_{j=1}^{R} w_{j}}
$$


Vamos assumir que o erro $\Delta N_{i}(E)$ relativo ao histograma $i$ seja proporcional a $\sqrt{\overline{N_{i}(E)}}$, ou seja, que os histogramas sigam, aproximadamente, a distribuição de Poisson, ou mesmo, aproximadamente, que os histogramas sejam gaussianas. Nesse último caso, pode-se mostrar que a média ponderada (com pesos $w_{i}$ ) de uma grandeza, tem sua variância $\sigma_{i}{ }^{2}$ minimizada se $w_{i}=1 / \sigma_{i}^{2}$. Portanto, os erros relacionados com a densidade de estados $\Omega_{i}(E)$, devido aos erros $\Delta N_{i}(E)$ dos histogramas é

$$
\sigma_{i}=\frac{\Delta N_{i}(E)}{n_{i}} \frac{Z_{i}}{e^{-\beta_{i} E}}=\frac{\sqrt{\overline{N_{i}(E)}}}{n_{i}} \frac{Z_{i}}{e^{-\beta_{i} E}}
$$

Agora é possível fazer a média ponderada (2.9.5). Usando $w_{i}=1 / \sigma_{i}^{2}$ e as expressões (2.9.6) e (2.9.3), chega-se à expressão

$$
\Omega(E)=\frac{\sum_{i} \overline{N_{i}(E)}\left[N_{i}(E) / n_{i}\right]\left[Z_{i} / e^{-\beta_{i} E}\right]}{\sum_{j} \overline{N_{j}(E)}}=\frac{\sum_{i} N_{i}(E)}{\sum_{j} n_{j} Z_{j}^{-1} e^{-\beta_{j} E}}
$$

onde foi usada a expressão (2.9.4) para substituir a grandeza desconhecida $\overline{N_{i}(E)}$. Deve-se notar que a expressão (2.9.7) ainda não é útil, pois as funções de partição $Z_{j}$ são desconhecidas. Porém, a função de partição é dada por

$$
Z_{k}=\sum_{E} \Omega(E) e^{-\beta_{k} E}
$$

Agora, as equações (2.9.7) e (2.9.8) são iteradas de forma autoconsistente. . Ou seja, parte-se de valores arbitrários para as funções de partição $Z_{k}$, que, usadas na expressão (2.9.7) permitem obter $\Omega(E)$. Este, por sua vez, inserido em (2.9.8) leva a novos valores para $Z_{k}$, e assim sucessivamente até que os valores das funções de partição $Z_{k}$, não variem significativamente. 


\section{Capítulo 3}

\section{ESTUDO CONFORMACIONAL DA PROTONECTINA ISOLADA EM MISTURA ÁGUA-TFE}

\subsection{Resultados da Dinâmica Molecular associada ao Método de Troca de Réplicas}

A Dinâmica Molecular (DM) fornece a evolução temporal do sistema em estudo. A análise das trajetórias fornece suporte para o estudo e compreensão dos fatores que contribuem para a variabilidade e estabilidade conformacional do peptídeo.

A variabilidade conformacional do peptídeo ao longo da dinâmica pode ser visualizada dos gráficos de padrões de estrutura secundária. Nas figuras de 3.1.1 a 3.1.16 estão apresentados esses padrões para um conjunto de 16 réplicas cobrindo um intervalo de temperaturas de 287 a $342 \mathrm{~K}$. Esse conjunto de simulações foi obtido usando o método de troca de réplicas que, como discutido na seção 2.7 , permite que o sistema vença barreiras de energia e cubra de maneira eficiente o espaço conformacional acessível ao peptídeo. Alguns detalhes das dinâmicas estão destacados nas legendas das figuras e, de forma geral, percebe-se delas que, mesmo com a elevação da temperatura, alguns padrões - hélice- $\alpha$ (na cor azul), "turn com B bridge" (na cor amarelo com preto) e de hélice-5 (na cor roxa) - aparecem em intervalos variáveis em diversas simulações. Além disso, com a elevação da temperatura, aumenta a fração do tempo em que o peptídeo permanece em conformações sem, ou com baixo percentual de resíduos em estruturas organizadas chamadas de conformações em "coil" ou aleatórias.

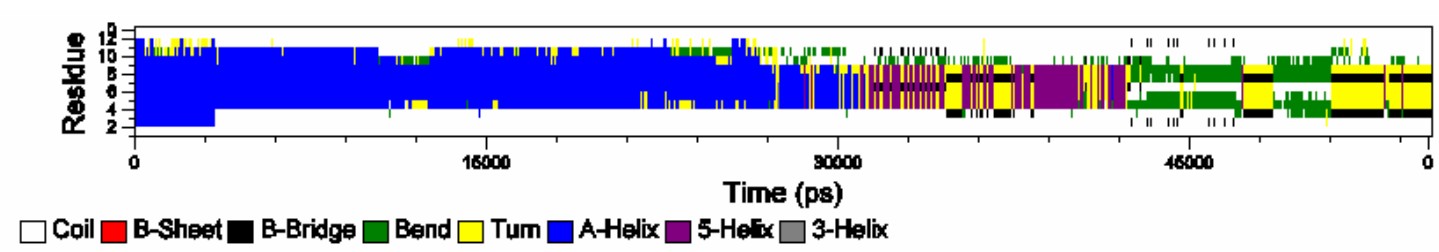

FIGURA 3.1.1: Gráfico de padrões de estrutura secundária para a temperatura $287 \mathrm{~K}\left(14^{\circ} \mathrm{C}\right)$. Por esta figura, verifica-se que até aproximadamente 30ns a conformação em $\alpha$-hélice (azul) é mantida. Após este período, esta conformação deixa de existir dando espaço a conformações em hélice-5 (roxo), turn com b-bridge (amarelo e 
preto, respectivamente) e conformações com alguns resíduos em bend (verde) e outros em coil (branco) aparecem.

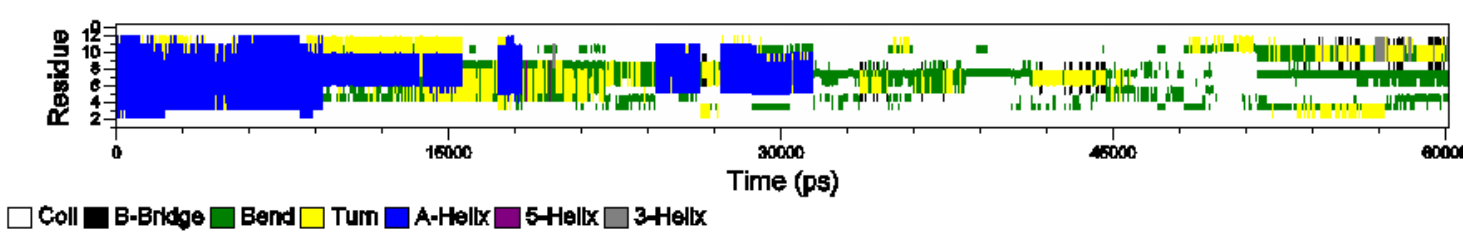

FIGURA 3.1.2: Gráfico de padrões de estrutura secundária para a temperatura $290 \mathrm{~K}\left(17^{\circ} \mathrm{C}\right)$. As conformações em $\alpha$-hélice aparecem constantes por volta dos 15 primeiros ns de simulação, após este intervalo de tempo estas conformações se intercalam com conformações com resíduos em turn (amarelo) e também bend (verde), até que em aproximadamente $32 \mathrm{~ns}$ o peptídeo aparentemente deixa de adotar conformação estruturada e assim se mantém até o fim da simulação.

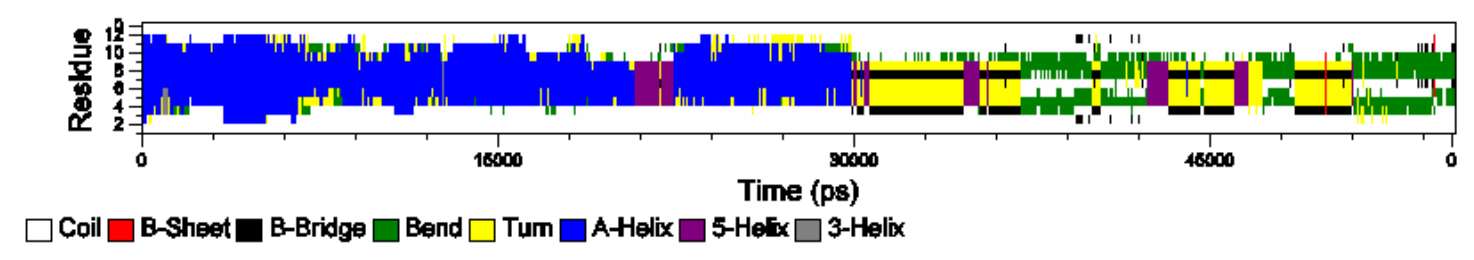

FIGURA 3.1.3: Gráfico de padrões de estrutura secundária para a temperatura $293 \mathrm{~K}\left(20^{\circ} \mathrm{C}\right)$. Nesta figura a conformação em hélice- $\alpha$ se mantém até 30 ns, neste período observa-se apenas num curto intervalo de tempo, aproximadamente de 21 a 22 ns, a ocorrência da conformação em hélice-5 (roxo). A partir de 30 ns são obtidas conformações em turn (amarelo) com b-bridge (preto), conformações em hélice-5 e até mesmo conformações com alguns resíduos em bend (verde).

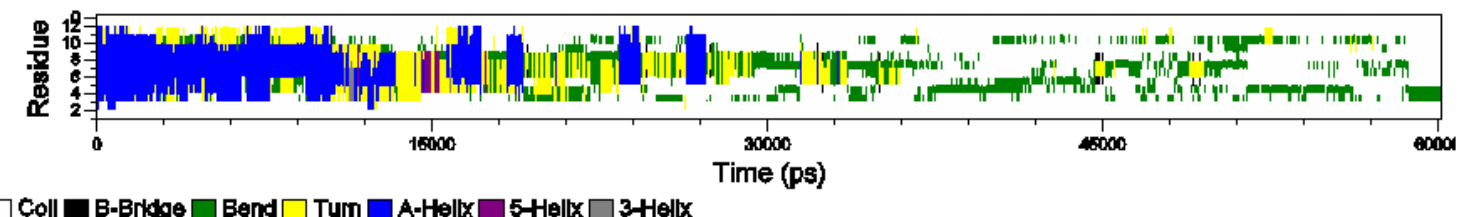

FIGURA 3.1.4: Gráfico de padrões de estrutura secundária para a temperatura $296 \mathrm{~K}\left(23^{\circ} \mathrm{C}\right)$. As conformações em $\alpha$-hélice (azul) apresentam-se até aproximadamente 13ns, a partir deste instante até por volta de $27 \mathrm{~ns}$ estas conformações são intercaladas com conformações em turn (amarelo), bend (verde) e hélice-5 (roxo). Depois dos primeiros 27 ns de simulação o peptídeo deixa de adotar conformação estruturada, resíduos em branco. 


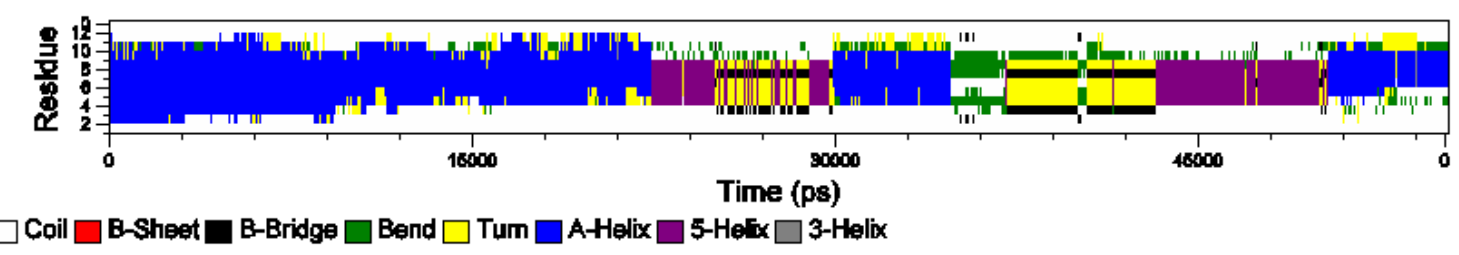

FIGURA 3.1.5: Gráfico de padrões de estrutura secundária para a temperatura $299 \mathrm{~K}\left(26^{\circ} \mathrm{C}\right)$. A hélice- $\alpha$ (azul) se mantém até aproximadamente 23ns, a partir deste instante é possível observar a formação de uma hélice-5 (roxo) que se mantém por volta de 2 ou 3 ns e depois se intercala com conformações em turn (amarelo) com b-bridge (preto). No instante de 30ns a $\alpha$-hélice é retomada e se mantém até cerca de 35ns, onde dá espaço para uma conformação com alguns resíduos em bend (verde), que dura aproximadamente $2 \mathrm{~ns}$. A conformação em turn com b-brige (amarelo com preto) volta a aparecer, desta vez por um intervalo de tempo significante ( $\sim 6 \mathrm{~ns})$, e em seguida a conformação em hélice-5 é novamente retomada, permanecendo por 8ns. Por fim, têm-se a conformação em $\alpha$-hélice.

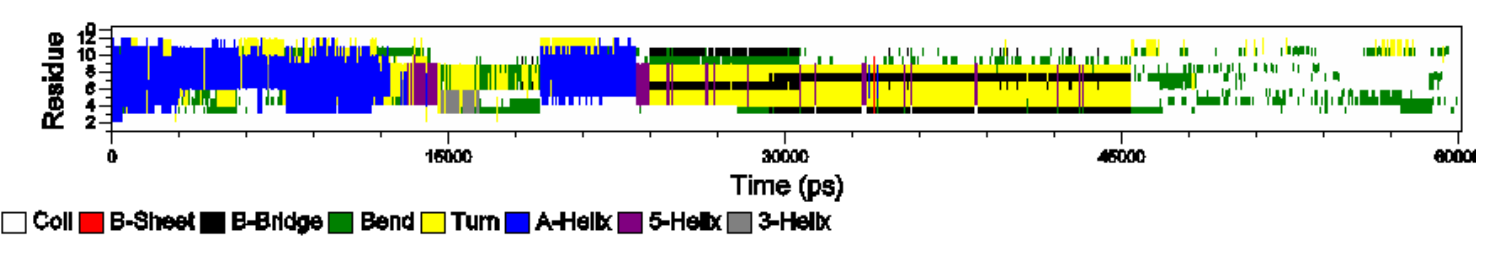

FIGURA 3.1.6: Gráfico de padrões de estrutura secundária para a temperatura $302 \mathrm{~K}\left(29^{\circ} \mathrm{C}\right)$. Nesta figura observa-se que até aproximadamente 12ns há a predominância da conformação em $\alpha$-hélice (azul). A partir daí até por volta de 19ns o peptídeo adota conformações em turn (amarelo), hélice-5 (roxo), bend (verde) e hélice-3 (cinza). O peptídeo retoma novamente a conformação em $\alpha$-hélice, permanecendo nela por cerca de 4 ou $5 \mathrm{ns,}$ depois disso este tipo de conformação não volta a aparecer e conformações em turn com b-bridge (amarelo com preto) lideram por um significante espaço de tempo ( $21 \mathrm{~ns})$. Em aproximadamente $45 \mathrm{~ns}$ o peptídeo perde qualquer tipo de conformação estruturada, apresentando a maioria de seus resíduos em coil (branco) e poucos deles em bend (verde).

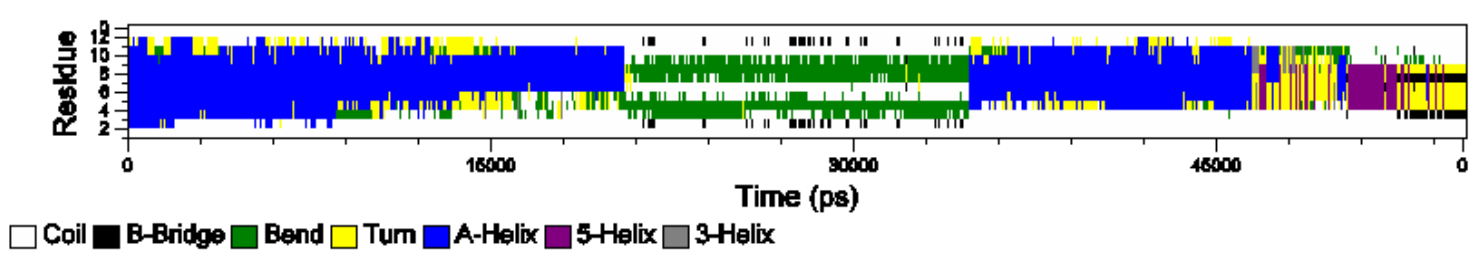

FIGURA 3.1.7: Gráfico de padrões de estrutura secundária para a temperatura $306 \mathrm{~K}\left(33^{\circ} \mathrm{C}\right)$. O peptídeo se apresenta na maior parte do tempo de simulação na conformação em $\alpha$-hélice (azul), ( 0-21ns; 35-46ns), este intervalo é intercalado por uma conformação que apresenta seus resíduos em bend (verde). E posteriormente à conformação em $\alpha$-hélice, são observadas conformações em turn (amarelo), hélice-5 (roxo) e turn com b-bridge (amarelo com preto). 


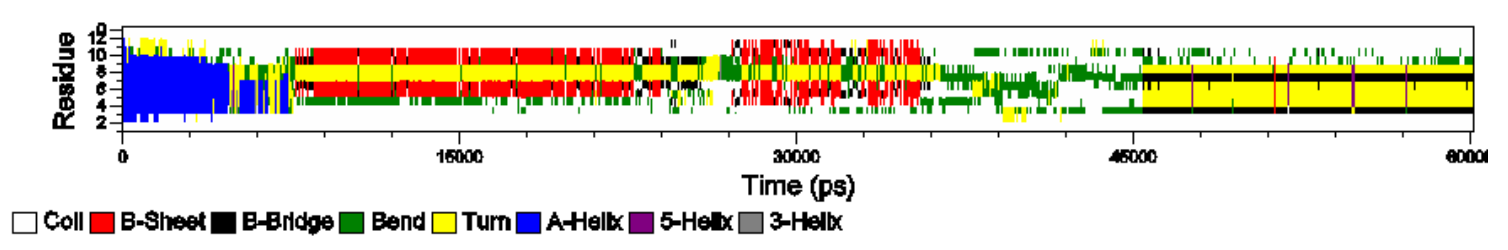

FIGURA 3.1.8: Gráfico de padrões de estrutura secundária para a temperatura $310 \mathrm{~K}\left(37^{\circ} \mathrm{C}\right)$. Nesta figura percebe-se que a presença da $\alpha$-hélice ocorre até aproximadamente $8 \mathrm{~ns}$, a partir daí verifica-se a formação de um padrão até então não observado, a folha beta (vermelho), que se estende até 36ns, momento onde começam aparecer conformações em coil (branco) com alguns resíduos em bend (verde). No instante aproximado de 45ns até o fim da simulação ocorre a presença dos padrões que são caracterizados por turn (amarelo) com b-bridge (preto).

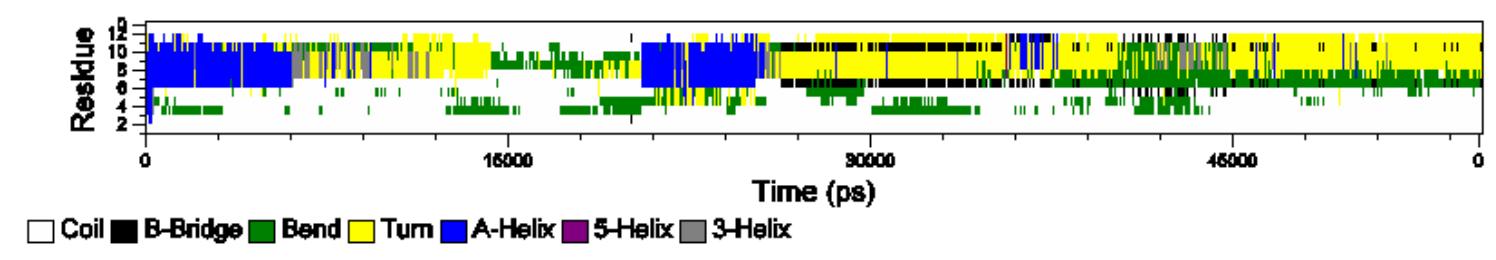

FIGURA 3.1.9: Gráfico de padrões de estrutura secundária para a temperatura $314 \mathrm{~K}\left(41^{\circ} \mathrm{C}\right)$. A conformação em

$\alpha$-hélice persiste nos primeiros 6ns de simulação, daí até aproximadamente 14ns ocorrem conformações com alguns resíduos em turn (amarelo). De 14 a 21ns a maioria dos resíduos do peptídeo se encontra em conformação aleatória (branco) com apenas alguns em bend (verde). A conformação em hélice- $\alpha$ torna aparecer pelo intervalo de tempo de 5 ns. A partir do instante 26ns conformação em turn com b-bridge (amarelo e preto, respectivamente) aparece por um intervalo de tempo razoável ( 26 a $36 \mathrm{~ns}$ ). Conformações em bend (verde), turn (amarelo) e hélice-3 (cinza) começam a ocorrer e assim permanecem até o fim da simulação.

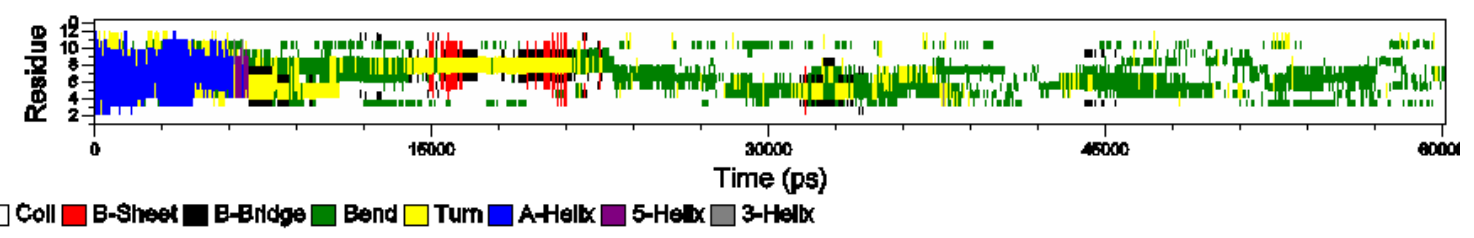

FIGURA 3.1.10: Gráfico de padrões de estrutura secundária para a temperatura $318 \mathrm{~K}\left(45^{\circ} \mathrm{C}\right)$. Nos primeiros $6 \mathrm{~ns}$ de simulação há a predominância da conformação em $\alpha$-hélice. Depois disso, em alguns instantes verifica-se a ocorrência de conformações estruturadas, tais como: folha beta (vermelho) e turn com b-bridge (amarelo com preto). No entanto na maior parte da simulação são observadas conformações aleatórias (branco) com alguns de seus resíduos em voltas, bend (verde). 


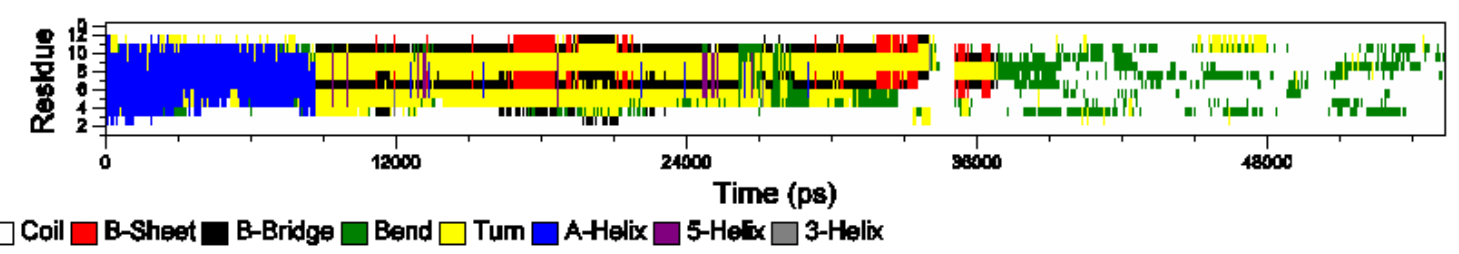

FIGURA 3.1.11: Gráfico de padrões de estrutura secundária para a temperatura $322 \mathrm{~K}\left(49^{\circ} \mathrm{C}\right)$. A conformação em $\alpha$-hélice se sustenta até 9ns, em seguida têm-se a conformação em turn com b-bridge (amarelo com preto) que é intercalada com algumas conformações em folha beta (vermelho), hélice-5 (pequenos traços em roxo) e bend (verde). A partir de aproximadamente 36ns o peptídeo deixa de apresentar conformação estruturada e passa a adotar conformação aleatória com alguns de seus resíduos em bend.

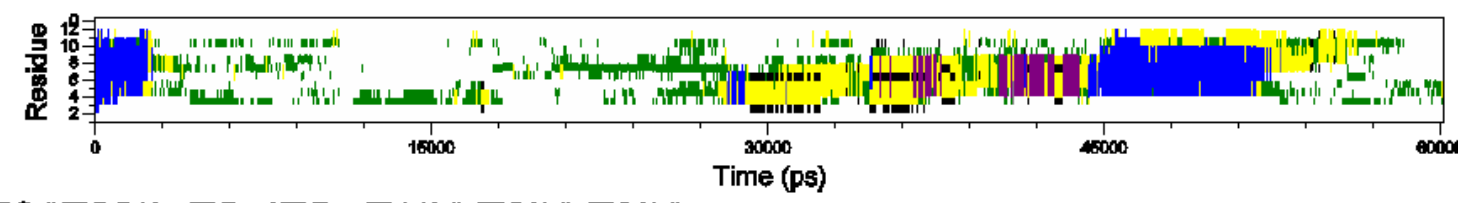

$\square$ Coll $\square$ B-Bridge $\square$ Bend $\square$ Tum $\square$ A-Hellx $\square$ 5-Hellx $\square$ 3-Helx

FIGURA 3.1.12: Gráfico de padrões de estrutura secundária para a temperatura $326 \mathrm{~K}\left(53^{\circ} \mathrm{C}\right)$. Antes de alcançar

3 ns de simulação a conformação em $\alpha$-hélice (azul) já é perdida, dando espaço a uma conformação aleatória

(branco) que permanece dessa forma por aproximadamente $24 \mathrm{~ns}$. A partir de $30 \mathrm{~ns}$ o peptídeo começa a se estruturar, passando por conformações em turn com b-bridge (amarelo com preto), hélice-5 (roxo) e alcança novamente a conformação em hélice- $\alpha$, que aparece entre 45 e 52 ns. A partir de 52 ns a conformação aleatória é novamente atingida e o peptídeo assim permanece até o fim da simulação.

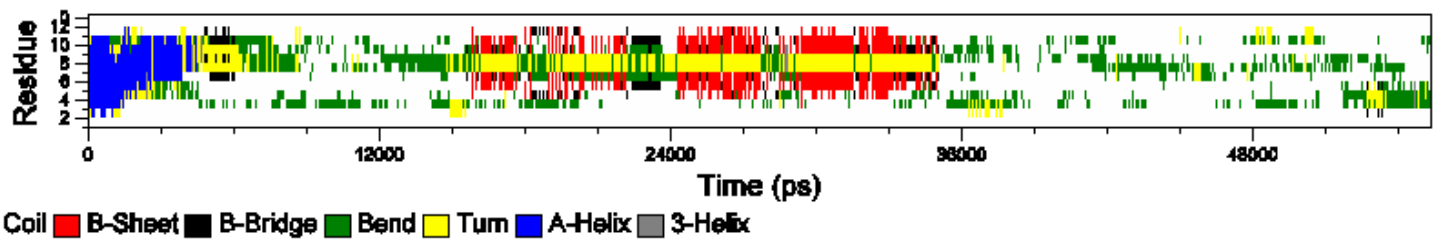

FIGURA 3.1.13: Gráfico de padrões de estrutura secundária para a temperatura $330 \mathrm{~K}\left(57^{\circ} \mathrm{C}\right)$. A conformação em $\alpha$-hélice é perdida logo nos primeiros ns de simulação, o peptídeo passa por conformações aleatórias (regiões em branco), consegue atingir algumas regiões parcialmente organizadas (folha beta, em vermelho; turn, em amarelo) mas permanece a maior parte da simulação em conformações em coil (branco).

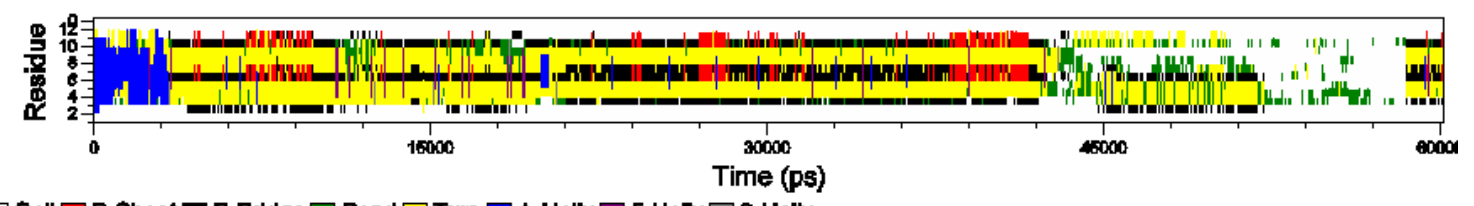

$\square$ Coll $\square$ B-Sheet $\square$ E-Endge $\square$ Bend $\square$ Tum $\square$ A-Hellx $\square$ 5-Helx $\square$ 3-Hellx

FIGURA 3.1.14: Gráfico de padrões de estrutura secundária para a temperatura $334 \mathrm{~K}\left(61^{\circ} \mathrm{C}\right)$. Após deixar a conformação em $\alpha$-hélice, em 3 ns, o peptídeo adota a conformação em turn (amarelo) com b-bridge (preto) e 
assim permanece até aproximadamente 42 ns. A partir deste instante é possível perceber que o peptídeo tem problemas em adotar alguma conformação, pois se verifica que alguns resíduos passam a se apresentar aleatoriamente (regiões brancas) e outros "tentam" alguma conformação, mas sem sucesso. Logo no fim da simulação, aparentemente, o peptídeo se organizou em conformação turn com b-bridge.

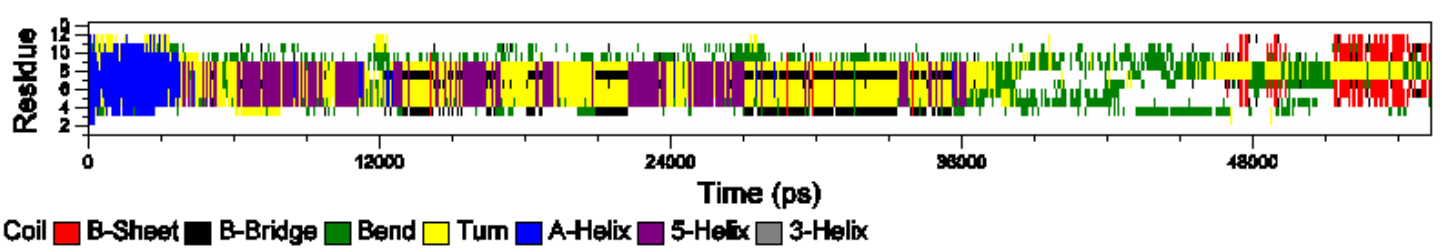

FIGURA 3.1.15: Gráfico de padrões de estrutura secundária para a temperatura $338 \mathrm{~K}\left(65^{\circ} \mathrm{C}\right)$. Este é mais um caso no qual o peptídeo perde a estrutura em hélice- $\alpha$ (azul) logo nos primeiros ns de simulação. A partir daí, e até aproximadamnte36 ns, varias conformações aparecem intercaladas: turn (amarelo), hélice-5 (roxo) e turn com b-bridge (amarelo com preto). Depois disso, observa-se um período ( 38 a $51 \mathrm{~ns}$ ) de conformação aleatória (resíduos em branco) com alguns resíduos em bend (verde). E por fim aparecem algumas conformações em folha beta (vermelho).

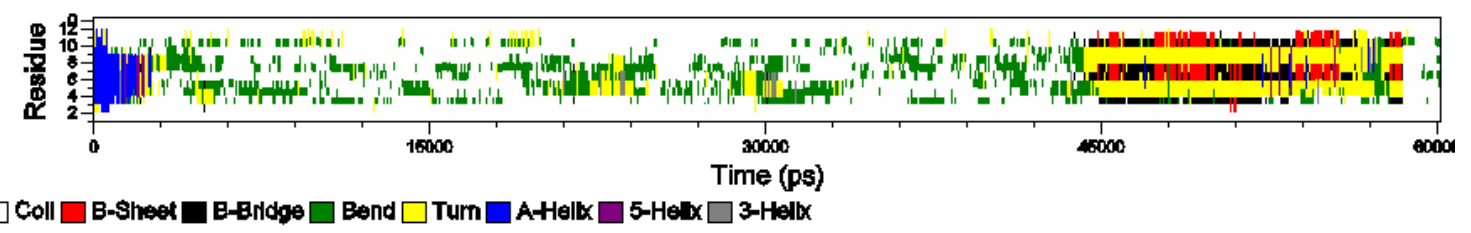

FIGURA 3.1.16: Gráfico de padrões de estrutura secundária para a temperatura $342 \mathrm{~K}\left(69^{\circ} \mathrm{C}\right)$. Na maior parte da simulação o peptídeo de encontra em conformação aleatória, adotando algum tipo de estruturação apenas no intervalo de 45 a 58 ns, no qual as conformações oscilam entre turn com b-bridge (amarelo com preto) e folha beta (vermelho).

A superfície de energia livre do sistema pode ser obtida aplicando-se o método dos histogramas (seção 2.9) a esse conjunto de réplicas. Para isso é necessário escolher parâmetros que representem de forma significativa as variações estruturais presentes no espaço conformacional do peptídeo. Nos dados que serão apresentados foram escolhidos o desvio quadrático médio, RMSD, em relação à configuração inicial (uma hélice- $\alpha$ ideal) e o valor da primeira componente principal, PCA1, obtida com o método de análise de componentes principais.

Para a obtenção deste resultado foram descartados os primeiros 15 ns de simulação a fim de que a "memória" da conformação inicial (hélice ideal) não influenciasse nos resultados. 
A superfície de energia livre está apresentada na figura 3.1.17, dela se verifica a presença de dois mínimos. O primeiro "populado" por estruturas parcialmente organizadas, com trechos de $\alpha$-hélice, hélice-5 ou turn com b-bridge, das quais, exemplos típicos estão destacados na figura 3.1.18. O segundo mínimo está populado por conformações aleatórias como as mostradas na figura 3.1.19. Para a obtenção destas conformações relacionaram-se os valores de RMSD e PCA1 encontrados em cada um dos mínimos, com as conformações adotadas durante as simulações; assim, para o primeiro mínimo de energia as conformações apresentadas na figura 3.1.18 (conformações organizadas) foram obtidas da réplica de $299 \mathrm{~K}$. As conformações apresentadas na figura 3.1.19, referentes ao segundo mínimo de energia (conformações em coil), foram obtidas na réplica de 302K.

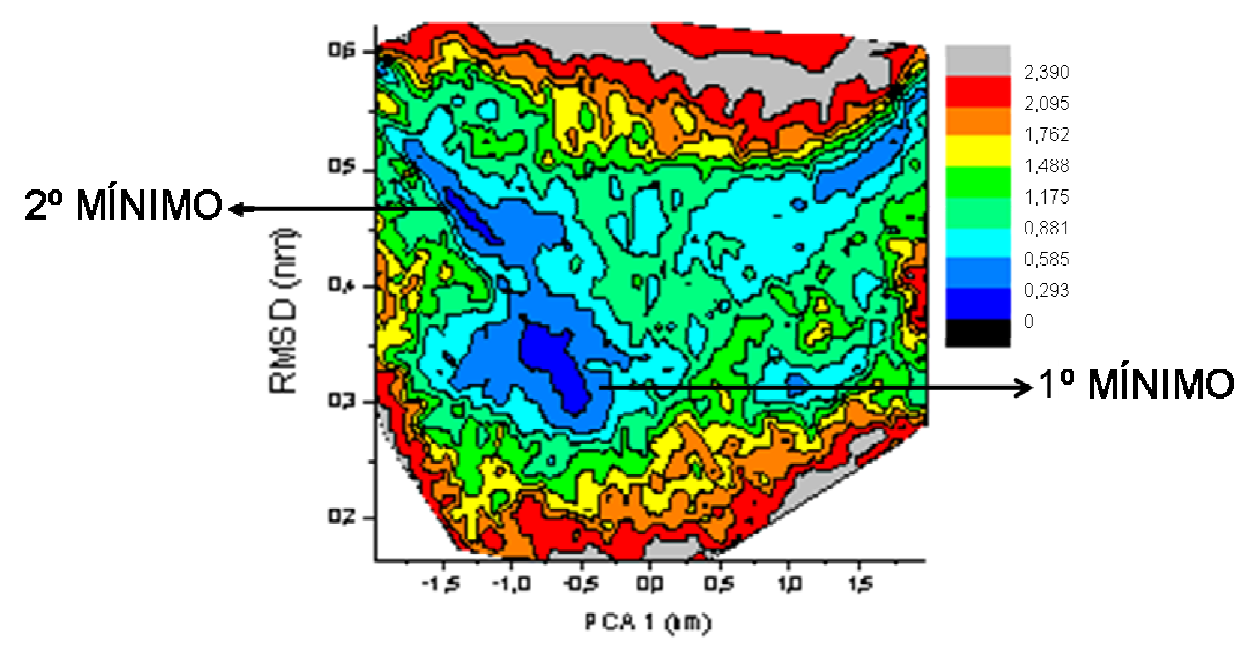

FIGURA 3.1.17: Superfície de Energia Livre em função do PCA-1 (nm) e do RMSD (nm) extrapolada na temperatura de $299 \mathrm{~K}$. 


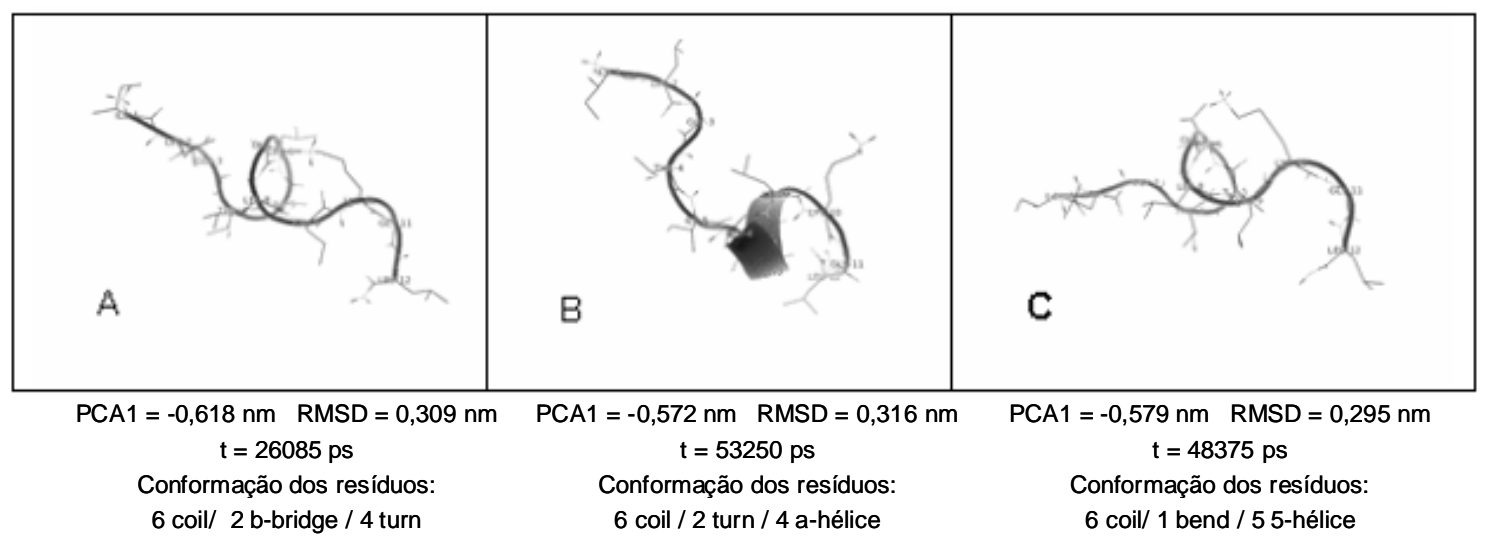

FIGURA 3.1.18: Estruturas parcialmente organizadas, obtidas no primeiro mínimo de energia da figura 3.1.17.

A) conformação com 4 resíduos em turn e 2 resíduos em b-bridge, esta conformação é apresentada em amarelo com preto no gráfico de padrões de estrutura secundária, figura 3.1.5 B) conformação com 4 resíduos em alfa hélice, no gráfico de padrões de estrutura secundária (figura 3.1.5) esta conformação se apresenta em azul. C) conformação com 5 resíduos em hélice-5, que no gráfico de padrões de estrutura secundária (figura 3.1.5) se apresenta em roxo.

As conformações apresentadas nas partes A e B da figura 3.1.19 são tipicamente classificadas como aleatórias ou em coil. Tais conformações são bem distintas das apresentadas na figura 3.1.18, as quais apresentam algum grau de estruturação. A existência de dois mínimos energéticos que apresentam conformações características (aleatórias estruturadas) permite uma estimativa do tempo gasto para a transição entre uma estrutura aleatória (coil) e uma enovelada ou vice-versa.

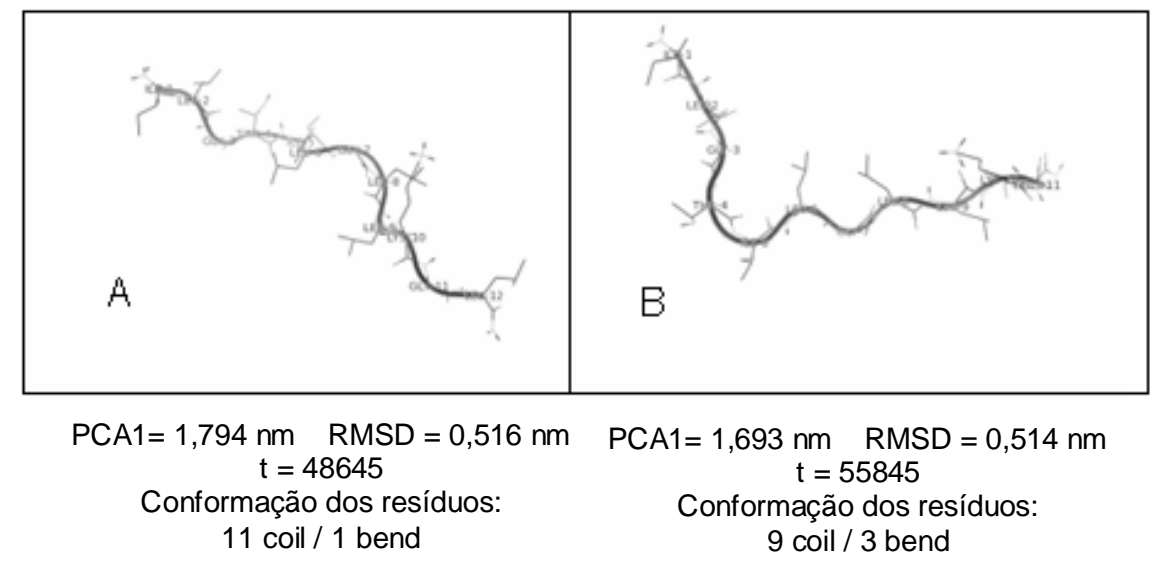

FIGURA 3.1.19: Conformações em coil obtidas no segundo mínimo de energia da figura 3.1.17. A) conformação com 11 resíduos em coil. B) conformação com 9 resíduos em coil. Ambas as conformações são 
apresentadas em branco com alguns resíduos em verde no gráfico de padrões de estrutura secundária da figura

3.1.6.

Para estimar o tempo de transição do peptídeo da estrutura em coil para a estrutura organizada é necessário conhecer a barreira de energia livre $(\Delta \mathrm{F})$ entre os dois mínimos das conformações (coil e organizadas) e o coeficiente de difusão, D, que é uma medida da capacidade do peptídeo de migrar entre diferentes conformações e está relacionado às flutuações de alguma grandeza que caracterize o sistema. Aqui foi usado o RMSD. O coeficiente de difusão (D) é dado por:

$$
D=\frac{\left\langle R M S D^{2}\right\rangle-\langle R M S D\rangle^{2}}{t}
$$

onde t é o tempo de decaimento da função de autocorrelação do RMSD, ou seja, o tempo médio necessário para o sistema perder a memória de uma dada conformação. Na figura 3.1.20A está mostrado o gráfico da energia livre como função do RMSD e na figura 3.1.20B o gráfico da função de autocorrelação do RMSD como função do tempo.
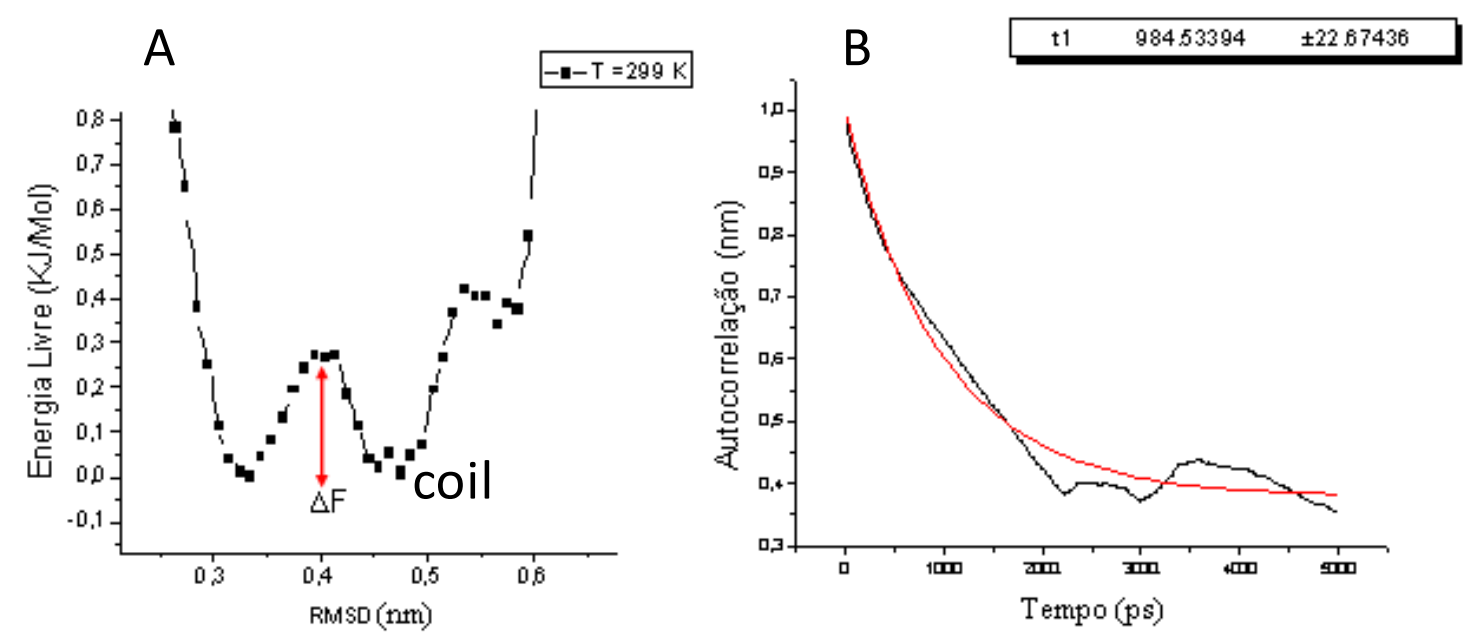

FIGURA 3.1.20: A) gráfico da energia livre (KJ/Mol) do sistema em função do RMSD (nm), a seta em vermelho indica a barreira de energia que o peptídeo deve vencer para atingir um outro estado. B) função de autocorrelação do RMSD que indica quanto tempo uma conformação leva para perder a "memória" da conformação anterior, em vermelho o ajuste da curva por uma função exponencial. 
O tempo de transição é obtido através da substituição dos devidos valores na equação abaixo:

$$
\sigma_{\text {Transition }}=\frac{e^{\frac{\Delta F}{K T}}}{D} \approx 165 n s
$$

O tempo médio necessário para a Protonectina conseguir vencer as barreiras energéticas entre a conformação aleatória e a estruturada é de aproximadamente 165 ns.

Uma estimativa das diferenças conformacionais entre estruturas típicas encontradas no primeiro mínimo de energia (figura 3.1.18) pode ser obtida pela análise do desvio quadrático médio (RMSD) entre elas e da análise das ligações de hidrogênio formadas na cadeia principal do peptídeo.

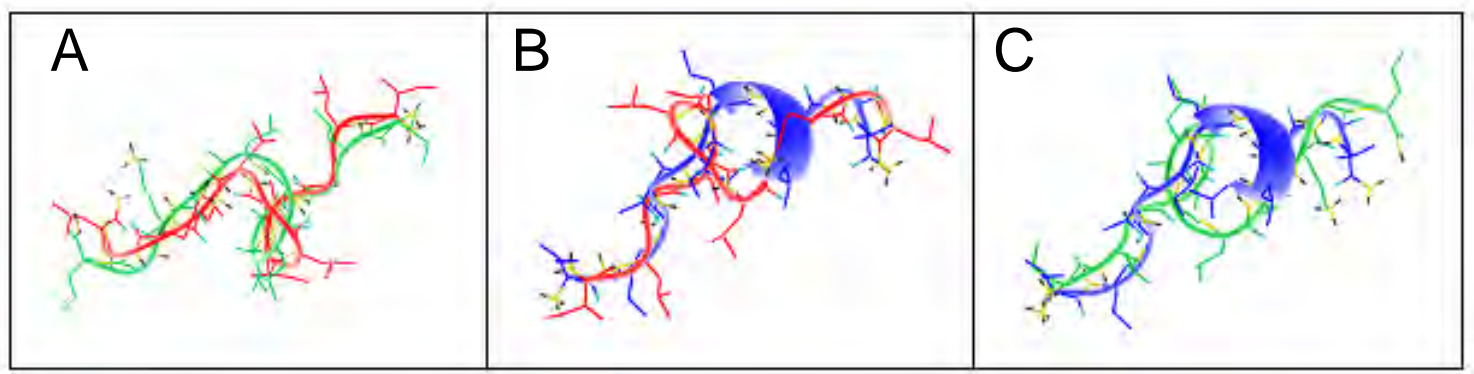

FIGURA 3.1.21: A) Sobreposição entre a conformação em hélice-5 (em vermelho) e a conformação em bbridge e turn (em verde). B) Sobreposição entre a com formação em $\alpha$-hélice (em azul) e a conformação em hélice-5 (vermelho). C) Sobreposição entre a $\alpha$-hélice (azul) e a conformação em turn e b-bridge (verde).

A figura acima é uma visualização das possíveis sobreposições de conformações típicas que foram encontradas no mínimo de energia. Verifica-se que as conformações em hélice-5 (vermelho) e turn com b-bridge (verde) têm uma sobreposição bastante significativa (figura 3.1.21A). Nas figuras 3.1.21B e 3.1.21C observa-se que há semelhança entre as conformações, no entanto a hélice-5 (vermelho) e a b-bridge com turn (verde) têm a volta, que representa seus resíduos estruturados, deslocada em relação à $\alpha$-hélice (azul). Os dados quantitativos para o RMSD entre as estruturas mostradas na Figura 3.1.21 estão dispostos na Tabela 3.1.1. Na tabela, a segunda coluna (Total) refere-se ao cálculo com todos os átomos do 
peptídeo, na coluna "backbone" o cálculo restringe-se aos átomos da cadeia principal enquanto na coluna "backbone 3 - 10" somente os átomos dos resíduos 3 ao 10 da cadeia principal são usados no cálculo do RMSD. Estes dados confirmam a análise qualitativa (visual), pois o menor valor do RMSD ocorre na comparação entre as estruturas em "turn com b-bridge" e em hélice-5 (figura 3.1.21A). A despeito de estarem no mesmo mínimo de energia livre a estrutura em hélice $\alpha$ difere significativamente das outras duas. Das figuras 3.1.21 B e C parece evidente que enquanto a hélice $\alpha$ se forma para a direita o "turn com b-bridge" e a hélice-5 se formam para a esquerda. Visualmente os maiores desvios da cadeia principal ocorrem na região dos aminoácidos estruturados, observação confirmada quando se compara os valores obtidos para o RMSD de toda a cadeia principal com os valores correspondentes envolvendo somente os resíduos de 3 ao 10. Essa inversão é possível pela presença dos resíduos de glicina que usualmente favorecem estruturas desorganizadas, em função de sua grande liberdade conformacional, e, em especial, podem proporcionar a formação de hélices$\pi$ (ou -5 ) para a esquerda.

\begin{tabular}{|c|c|c|c|}
\hline \multicolumn{4}{|c|}{ TABELA 3.1.1: Valores do RMSD (nm) entre as conformações sobrepostas da figura 3.1.21. } \\
\hline Fig. 3.1.21 & TOTAL & BACKBONE & BACKBONE 3 - 10 \\
\hline A & 0,274 & 0,177 & 0,082 \\
\hline B & 0,557 & 0,378 & 0,328 \\
\hline C & 0,564 & 0,348 & 0,317 \\
\hline
\end{tabular}

As ligações de hidrogênio podem ocorrer entre os grupos $\mathrm{CO}$ e $\mathrm{NH}$ de diferentes resíduos da cadeia principal do peptídeo, podendo ser classificadas de várias maneiras. Neste trabalho foram identificadas as ligações por hidrogênio $n$ com $n+4$, isto é, a ligação por hidrogênio entre o n-ésimo resíduo com o $n+4$-ésimo e entre o $n$ - ésimo e $n+5$ - ésimo resíduos. A figura 3.1.22 exibe o gráfico do número total de ligações por hidrogênio, $n-n+4$ e $n-n+5$, em função do tempo de simulação para a réplica de 299K. 

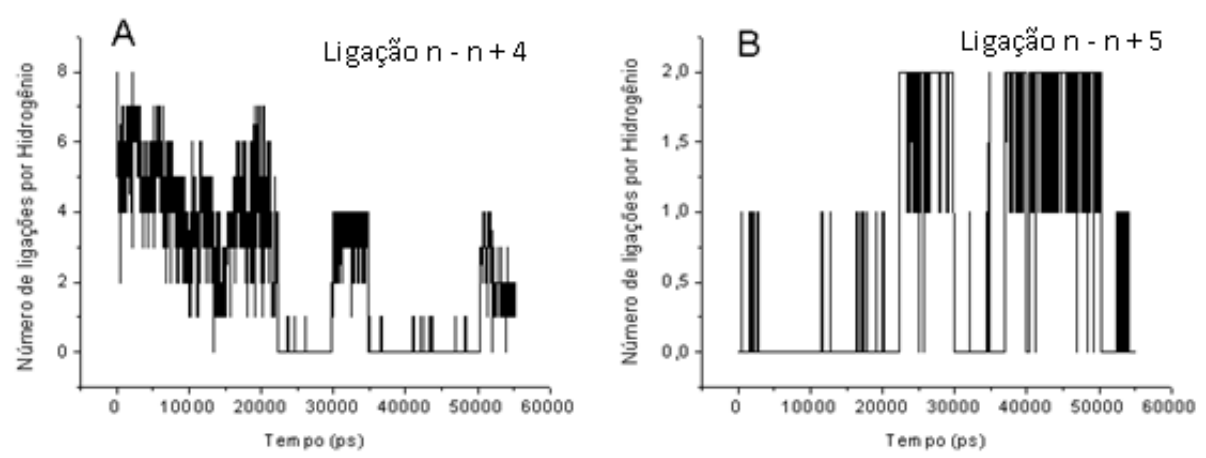

FIGURA 3.1.22: Número total de ligações por hidrogênio como função do tempo de simulação. A) Ligações n com $n+4$. B) Ligação $n$ com $n+5$.

Da análise conjunta entre a figura 3.1.22 e a figura de padrões de estrutura secundária para a réplica de $299 \mathrm{~K}$ (3.1.5) verifica-se que nos intervalos de tempo onde há a ocorrência de conformações em $\alpha$-hélice $(0$ - 22 ns, 30-35 ns e 50ns até o fim da simulação) há a predominância das ligações por hidrogênio do tipo $n-n+4$ (no máximo 8 e no mínimo 1), o número dessas ligações está relacionado com a quantidade de resíduos que se encontram em $\alpha$-hélice, de maneira que quanto maior o número de resíduos nessa conformação mais ligações $n-n+4$ existem. No entanto, nos demais intervalos de tempo, com exceção de 35 a 37 ns, são observadas 1 ou 2 ligações por hidrogênio do tipo $n-n+5$, as conformações que são encontradas nestas situações são as conformações em turn com b-bridge e hélice-5. No intervalo 35 a 37 ns, não é observada nenhum tipo de ligação por hidrogênio e o peptídeo não adota nenhuma conformação estruturada.

Conclui-se destas análises que o ganho de ligações de hidrogênio do tipo $n-n+5$ contribui para a perda das ligações do tipo $n-n+4$ e com isso a desestruturação da hélice- $\alpha$ deste peptídeo é observada. Os 3 resíduos de Glicina dispostos na forma $n-n+4$ (posições 3,7 e 11) são os responsáveis pela instabilidade destas ligações de hidrogênio, devido a grande variabilidade conformacional das glicinas, isso pode ser verificado da figura 3.1.23, da qual se verifica que os diedrais $\varphi$ e $\psi$, dos resíduos de aminoácidos anteriores às glicinas diferem significativamente da região típica de $\alpha$-hélice $\left(-47^{\circ},-57^{\circ}\right)$ do gráfico de Ramachandram. Além disso, a ausência de cadeia lateral facilita o acesso livre das moléculas do solvente a esses resíduos. 


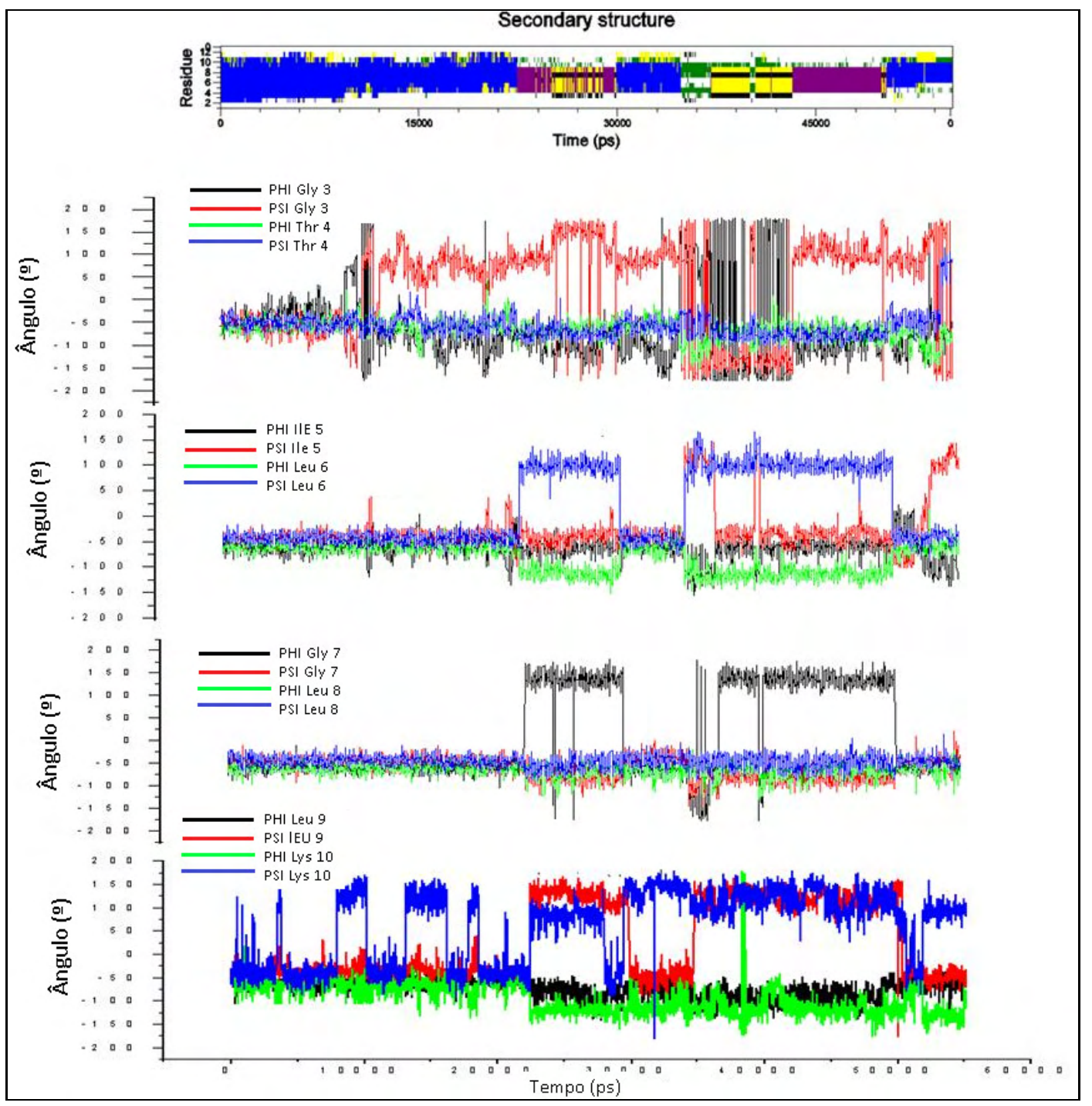

FIGURA 3.1.23: Análise dos diedrais, $\varphi$ e $\psi$, de alguns resíduos da Protonectina para a réplica de 299K. 


\subsection{Resultados das Dinâmicas de Equilíbrio}

Algumas conformações da Protonectina obtidas nas simulações por troca de réplicas foram escolhidas como ponto de partida para simulações por DM de equilíbrio. Entre as conformações escolhidas encontram-se as aquelas típicas encontradas no primeiro mínimo de energia livre, mostrado na figura 3.1.18, uma conformação que apresenta quatro de seus resíduos em folha beta, uma com todos os seus resíduos em conformação aleatória e outra com 7 resíduos em $\alpha$-hélice. Resultando em 6 simulações distintas, todas simuladas por aproximadamente $60 \mathrm{~ns}$ na mesma temperatura e pressão. A tabela 3.2.1, abaixo, exibe a relação das simulações e à temperatura onde tais conformações foram obtidas.

\begin{tabular}{|c|c|}
\hline & TABELA 3.2.1: Estrutura inicial \\
\hline Simulação 1 & Conformação com 5 resíduos em hélice-5 e 7 resíduos em coil, 299K \\
\hline Simulação 2 & Conformação com 5 resíduos em coil, 2 em b-bridge, 1 bend e 4 em turn, 299K \\
\hline Simulação 3 & Conformação com 5 resíduos em coil, 1 bend, 2 em turn e 4 em $\alpha$-hélice, 299K \\
\hline Simulação 4 & Conformação com 6 resíduos em coil, 4 em folha beta e 2 em turn, 302K \\
\hline Simulação 5 & Todos os resíduos em coil, 302K \\
\hline Simulação 6 & Conformação com 4 resíduos em coil, 1 em turn e 7 em $\alpha$-hélice, 299K \\
\hline
\end{tabular}

Os gráficos de padrões de estruturas secundárias referentes a cada uma dessas simulações são apresentados na figura 3.2.1 a - f. Percebe-se nas figuras 3.2.1a e 3.2.1b, que suas conformações oscilam entre turn com b-bridge (amarelo com preto) e hélice-5 (roxo), verifica-se também a presença, por pequenos intervalos, de algumas conformações em $\alpha$ hélice (riscos em azul). O fato das conformações em "turn com B-bridge" e hélice-5 oscilarem entre si indica, como discutido anteriormente, que as diferenças entre elas são pequenas, além disso, elas se apresentam de forma estável nestes gráficos, ao contrário das conformações em hélice- $\alpha$ que embora acessadas, mantém-se por intervalos muito curtos. Para as duas simulações nas quais a estrutura de partida continha resíduos em hélice- $\alpha$, as trajetórias dinâmicas são muito diferentes, para a simulação 3 o segmento com estrutura helicoidal se perde e ao final obtêm-se um peptídeo desestruturado enquanto para a simulação 6 a estrutura parcialmente em hélice- $\alpha$ oscila, perde parte da estrutura, mas um número significativo de resíduos permanece nesse padrão por praticamente toda a dinâmica. As estruturas iniciais eram diferentes somente no percentual de resíduos estruturados, cerca de $33 \%$ na simulação 3 e cerca de $58 \%$ na simulação 6 . A outra diferença é a atribuição de velocidades inerente ao 
protocolo da dinâmica molecular. A trajetória final é uma evidência de que o número de resíduos inicialmente estruturados na simulação 3 não foi suficiente para manter o peptídeo com a estrutura de partida, embora ela tenha perdurado por cerca de 12 ns de simulação. Após esse período, o peptídeo "visita" conformações em "turn com B-bridge", mas também não se estabiliza nesse tipo de estrutura, terminando os $60 \mathrm{~ns}$ desestruturado. O oposto se verifica na simulação 6 , na qual um núcleo em hélice- $\alpha$ está presente em praticamente toda a simulação. Nos pequenos intervalos em que isso se perde o peptídeo assume conformação em "turns" e em hélice-5. Na figura 3.2.1d verifica-se que o peptídeo permanece um percentual significativo do tempo com um número significativo de resíduos em folha beta, oscilando entre essa conformação e as conformações "turn com B-bridge" e, sobretudo, aleatória. Na simulação que partiu do peptídeo em estrutura aleatória, figura 3.2.1e, percebe-se que ele não conseguiu vencer a barreira de energia que separa essa conformação de uma estruturada, pois ele permanece em coil durante toda a simulação. 


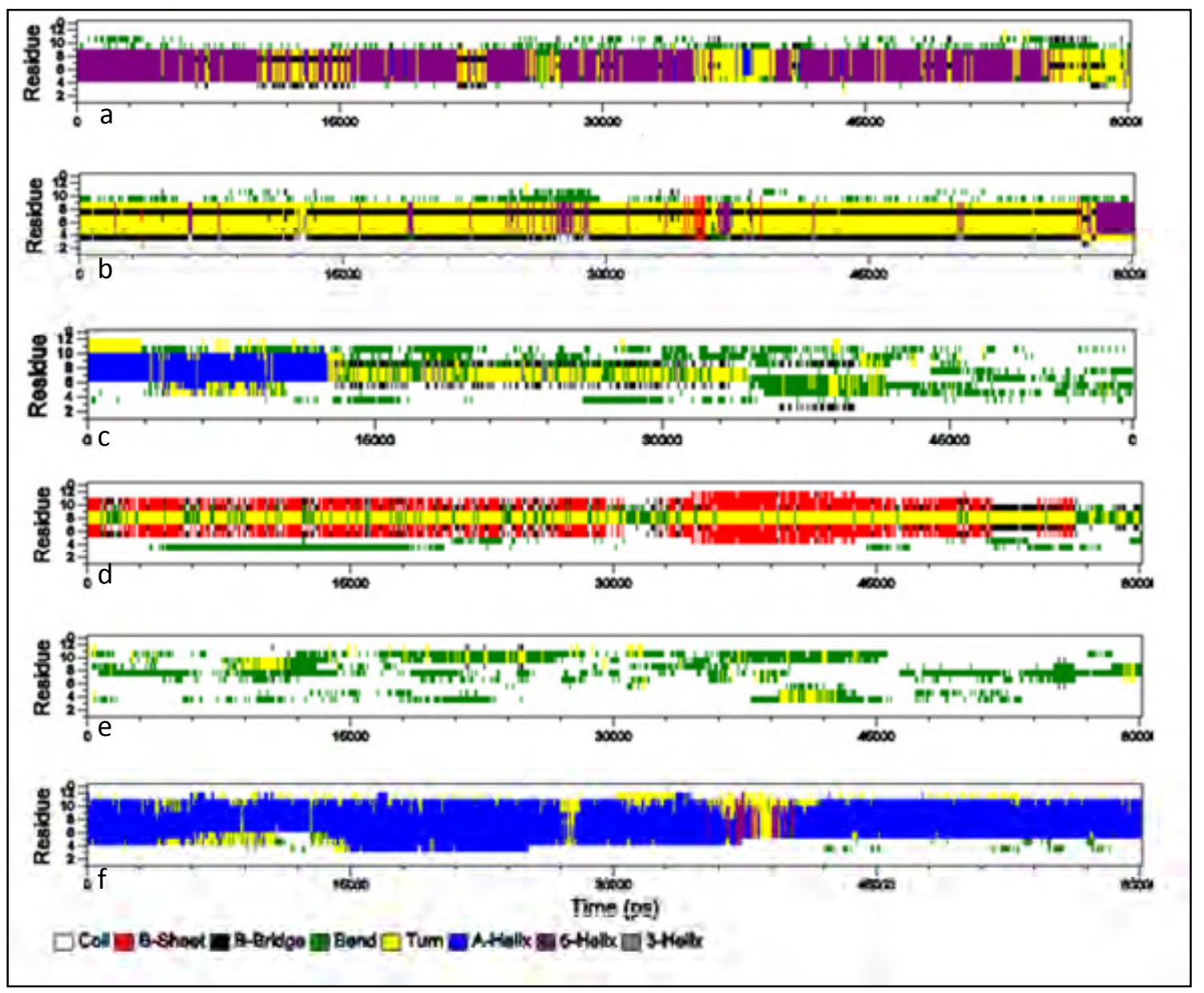

FIGURA 3.2.1: Gráficos de padrões de estrutura secundária para as simulações de equilíbrio, 299 K.

Considerando-se que o conjunto destas simulações forme uma amostragem do espaço conformacional pode-se obter o tempo médio de permanência do peptídeo com um dado tipo de estrutura, ou conformação. Os resultados estão dispostos na Tabela 3.2.2. A conformação em hélice- $\alpha$, por exemplo, apresenta um percentual de $21,3 \%$ nos dados experimentais obtidos pela análise dos espectros feitos com o auxilio do programa CDPro, enquanto que sua porcentagem é de $19 \%$ nos dados obtidos por DM de equilíbrio. A conformação em turn com b-bridge obtida pela DM mostrou-se presente por volta de $24 \%$ do tempo total de simulação enquanto que a conformação em turn, obtida experimentalmente, possui uma porcentagem de 20,1 \%. As estruturas não ordenadas ocorrem em $33 \%$ da simulação por DM enquanto nas análises experimentais esse número é de $26,7 \%$. Obviamente uma palavra de cautela é necessária, pois os dados experimentais se referem ao percentual médio de resíduos nas 
conformações indicadas enquanto os resultados das simulações representam o percentual do tempo em que o peptídeo apresentou algum tipo de estruturação. Também não se deve esquecer que os resultados experimentais representam médias sobre um número muito grande de moléculas.

TABELA 3.2.2: Porcentagem de permanência de cada conformação durante as simulações, $299 \mathrm{~K}$

\begin{tabular}{|c|c|}
\hline Conformação & \% Permanência \\
\hline $\begin{array}{c}\alpha \text {-hélice } \\
\text { (azul }- \text { fig. 3.2.1c e 3.2.1f) }\end{array}$ & $\sim 19 \%$ \\
\hline $\begin{array}{c}\text { Hélice-5 } \\
\text { (roxo - fig. 3.2.1a) }\end{array}$ & $\sim 14 \%$ \\
\hline $\begin{array}{c}\text { Turn com B-bridge } \\
\text { (amarelo com preto-fig.3.2.1b) }\end{array}$ & $\sim 24 \%$ \\
\hline $\begin{array}{c}\text { Folha beta } \\
\text { (vermelho - fig. 3.2.1d) }\end{array}$ & $\sim 10 \%$ \\
\hline Outras & $\sim 33 \%$ \\
\hline
\end{tabular}

A formação e manutenção da estrutura secundária estão intimamente relacionadas às ligações de hidrogênio que ocorrem entre os resíduos da cadeia principal do peptídeo, por isso, suas possíveis formações foram analisadas a fim de identificar as características de cada uma das estruturas obtidas através das simulações. Os resultados são apresentados como percentual médio de duração das pontes de hidrogênio em função do tempo de simulação.

Neste trabalho foram analisadas as ligações tipo $n-n+j$, com $j=1,2$,..,7. Os resultados relevantes desta análise estão apresentados na tabela 3.2.3, da qual se verifica que as estruturas encontradas nas simulações 1 e 2 apresentam porcentagem significativa de ligação por hidrogênio entre os resíduos CO3-NH8 e CO4-NH9 (ligação $n-n+5$ ). As estruturas da simulação 4 apresentam ligações $n-n+3$ entre os grupos CO6 e NH9 e n - n + 7 entre os grupos CO4 e NH11. Por fim, na simulação 6 há ocorrência de pontes de hidrogênio do tipo $\mathrm{n}-\mathrm{n}+4$, em porcentagem significativa, para os grupos: CO4-NH8, CO5NH9, CO6-NH10 e CO7-NH11. A simulação 5 não apresentou porcentagem significativa de 
pontes de hidrogênio, e a simulação 3 apresenta uma pequena porcentagem de ligações do tipo $n-n+4$, que ocorre somente no período de predominância de $\alpha$-hélice.

TABELA 3.2.3: Porcentagem de permanência dos diferentes tipos de Ligações de hidrogênio entre os grupos $\mathrm{CO}$ e NH da cadeia principal do peptídeo, para cada uma das simulações.

Porcentagem das Ligações de Hidrogênio $n-n+3$

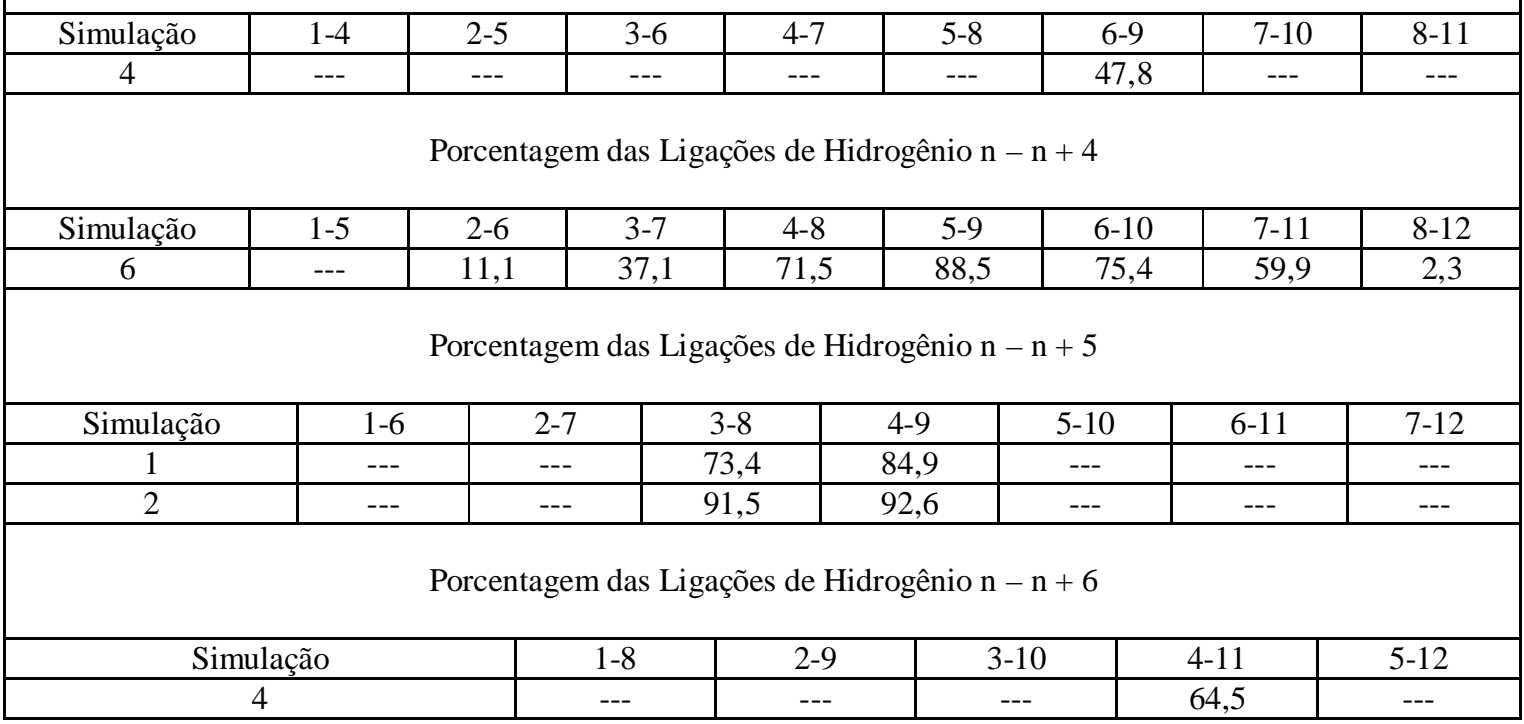

A análise da tabela acima nos permite confirmar que: (1) as ligações de hidrogênio do tipo $n-n+3$ e $n-n+7$ ocorrem quando a conformação é uma folha beta. (2) na ocorrência de conformações em $\alpha$-hélice o tipo de ponte de hidrogênio que prevalece é o $n-n+4$. (3) as conformações em Turn com B-bridge e hélice-5 ocorrem quando as ligações de hidrogênio são do tipo $n-n+5$. As porcentagens apresentadas nesta tabela, em sua maioria, são aproximadamente iguais ou maiores que $50 \%$, que é um tempo significativo de formação e manutenção destas ligações. As que apresentam valores inferiores a 50\% são as ligações por hidrogênio do tipo $n-n+4$ entre os resíduos 2-6, 3-7 e 8-12 da simulação 6.

Relevantes também para a análise do sistema são as ligações de hidrogênio entre a água /TFE e os grupos NH da cadeia principal. Assim, foram investigadas as pontes de hidrogênio entre o NH de cada resíduo da cadeia principal das simulações 1, 2, 4, 5 e 6, e o átomo de oxigênio (OW) da água, e os átomos de oxigênio (OAT) das moléculas de TFE. A simulação 3 não foi investigada porque apresenta padrões análogos aos das simulações 6 ( $\alpha$ - 
hélice), entre 0 e 12 ns, e simulação 5 (coil), no restante da simulação. Os resultados relevantes são encontrados na tabela 3.2.4.

TABELA 3.2.4: Porcentagem de permanência das Ligações de hidrogênio entre o grupo NH de cada resíduo da cadeia principal do peptídeo e as moléculas de água ou TFE.

Para as simulações $1,2,4,5$ e 6 .

Porcentagem de Permanência das Pontes de Hidrogênio entre o Grupo NH e o Átomo de OW das moléculas de Água

\begin{tabular}{|c|c|c|c|c|c|c|c|c|c|c|c|}
\hline & NH2 & NH3 & NH4 & NH5 & NH6 & NH7 & NH8 & NH9 & NH10 & NH11 & NH12 \\
\hline S1 & 17 & --- & 17 & --- & --- & --- & --- & -- & -- & --- & --- \\
\hline S2 & 22 & --- & 27 & --- & --- & --- & --- & --- & --- & --- & --- \\
\hline S4 & 21 & --- & --- & --- & --- & --- & --- & --- & --- & --- & 21 \\
\hline S5 & 21 & --- & --- & --- & --- & --- & --- & -- & -- & --- & --- \\
\hline S6 & --- & --- & --- & --- & --- & --- & --- & --- & --- & --- & --- \\
\hline
\end{tabular}

Porcentagem de Permanência das Pontes de Hidrogênio entre o Grupo NH e o Átomo de OAT das moléculas de TFE

\begin{tabular}{|c|c|c|c|c|c|c|c|c|c|c|c|}
\hline & NH2 & NH3 & NH4 & NH5 & NH6 & NH7 & NH8 & NH9 & NH10 & NH11 & NH12 \\
\hline S1 & 75 & 82 & --- & --- & 65 & 87 & --- & --- & 80 & 85 & $\mathbf{6 0}$ \\
\hline S2 & 70 & --- & --- & --- & 50 & 98 & --- & --- & 72 & 84 & $\mathbf{6 8}$ \\
\hline S4 & 71 & 58 & 54 & 76 & --- & 67 & 76 & --- & 74 & --- & --- \\
\hline S5 & 72 & 75 & 51 & 68 & 81 & 79 & 74 & 78 & 72 & 74 & $\mathbf{6 7}$ \\
\hline S6 & 80 & 75 & --- & --- & --- & --- & --- & --- & -- & --- & $\mathbf{5 2}$ \\
\hline
\end{tabular}

Essa tabela, em conjunto com os dados da Tabela 3.2.3 mostram que: 1) os grupos amina de cada resíduo estão preferencialmente circundados por moléculas de TFE, sendo pequeno o tempo de permanência de ligações de hidrogênio com a água, mesmo para os resíduos do $\mathrm{N}$ e C-terminais; 2) os vazios da tabela acima correspondem às ligações significativas entre o $\mathrm{CO}$ e $\mathrm{NH}$ da cadeia principal, relatadas na tabela 3.2.3. Como o tempo de permanência das ligações de hidrogênio tanto intra-peptideo como com o TFE das simulações 1 e 2 são muito semelhantes, uma conjectura possível para a relativa estabilidade dessas simulações seria a facilidade de passar de uma corformação à outra e à dificuldade de alterar a estrutura de ligações pelo hidrogênio com o TFE, uma vez que essa molécula ocupa um volume de quatro a cinco moléculas de água, requerendo, portanto, energia maior para ser deslocada. Para a simulação 6 , por outro lado, o número de ligações de hidrogênio intra- 
cadeia peptídica é alto e quatro delas se mantém por períodos maiores do que cinqüenta porcento do tempo total, além disso, as pontes com o oxigênio do TFE e mesmo da água ocorrem por períodos pequenos, com exceção dos resíduos do $\mathrm{N}$ e C- terminal, que por outro lado nunca são classificados na estrutura helicoidal.

As análises dos resultados para as ligações de hidrogênio apresentadas acima, sugerem que os resíduos de glicina (posições 3, 7 e 11) presentes na seqüência da protonectina têm forte influência na formação e/ou manutenção da estrutura helicoidal deste peptídeo. Por não possuir cadeia lateral, a presença deste resíduo na seqüência peptídica permite que, na região onde eles se encontram, ocorra uma maior aproximação das moléculas de solvente ao redor da cadeia principal. Este fato é evidenciado pelos resultados da tabela 3.2.4, na qual é possível verificar que os grupos $\mathrm{NH}$ dos resíduos de glicina e dos resíduos próximos à glicina, apresentam valores significativos para as porcentagens de permanência das pontes de hidrogênio com o átomo de oxigênio das moléculas de TFE. A ocorrência destas ligações influencia a manutenção das ligações $\mathrm{n}-\mathrm{n}+4$ intra-cadeia, pois o grupo $\mathrm{NH}$ (do resíduo $\mathrm{n}+$ 4) que deveria formar a ligação com o grupo $\mathrm{CO}$ do resíduo n, encontra-se quase que durante todo o tempo de simulação associado, por pontes de hidrogênio, com o átomo de oxigênio da molécula de TFE, desfavorecendo a ligação intra-cadeia do tipo $n-n+4$.

A área acessível ao solvente foi calculada para as simulações 1, 2, 4, 5 e 6 . O resultado está apresentado na figura 3.2.2. A análise do gráfico da área acessível ao solvente para estas simulações permite concluir que a simulação 5, que não adota conformação estruturada durante todo o tempo, é a que apresenta o maior valor médio para a área acessível ao solvente $(16,0 \pm 0,7)$, seguido das simulações 1 (conformação em hélice-5) e 2 (conformação em turn com b-bridge): $14,2 \pm 0,5$ e 14,1 $\pm 0,5$ respectivamente. As conformações em Folha- $\beta$ (simulação 4) e $\alpha$-Hélice (simulação 6), como já esperado, são as que possuem o menor valor médio da área acessível ao solvente 13,4 \pm 0,8 e 13,5 \pm 0,6 respectivamente. Para a simulação 3 (dados não incluídos), o comportamento da área acessível é tipicamente o mesmo das simulações 6 e 5 nos períodos em que o peptídeo está em conformação helicoidal ou aleatória respectivamente. 


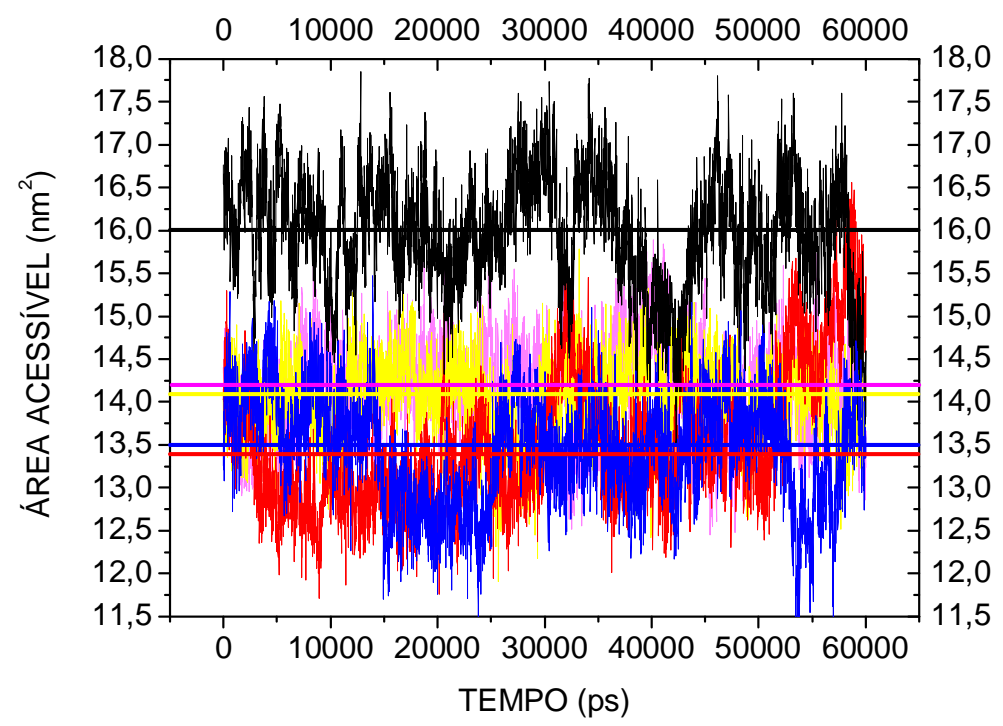

FIGURA 3.2.2: Área acessível ao Solvente $\left(\mathrm{nm}^{2}\right)$ como função do tempo de simulação (ps). Em preto simulação 5 (coil), em vermelho simulação 4 (folha beta), em azul simulação 6 ( $\alpha$-hélice), em magenta simulação 1 (hélice5) e em amarelo simulação 2 (turn com b-bridge). As retas representam a média temporal de cada simulação. 


\section{Capítulo 4}

\section{RESULTADOS DA DINÂMICA DE EQUILÍBRIO DA PROTONECTINA ASSOCIADA COM A PROTONECTINA 1-6}

Os dados experimentais, discutidos no capitulo 1, revelam que, quando associadas na proporção 1:1, a Protonectina e a Protonectina 1-6 têm sua ação hemolítica elevada e sua atividade quimiotática diminuída. Uma conjectura é que esse fato esteja relacionado à uma estruturação mais adequada das moléculas do solvente na região dos peptídeos associados ou maior anfipaticidade estrutural, no aumento de tamanho e da hidrofobicidade do complexo.

Para a simulação de equilíbrio da Protonectina associada com a Protonectina 1-6 montou-se uma caixa cúbica de aproximadamente $5,4 \mathrm{~nm}$ de aresta com os dois peptídeos, 396 moléculas de TFE, 3435 moléculas de água e 3 íons de cloro, que são utilizados para neutralizar a caixa. A conformação inicial da protonectina continha 6 resíduos em hélice, obtida da simulação de troca de réplicas na temperatura de $299 \mathrm{~K}$. E a protonectina 1-6 em conformação aleatória (obtida na réplica de 302K). A maneira como foram dispostos os peptídeos na caixa de simulação, está apresentada na figura 2.6.1., da qual foram subtraídas as moléculas do solvente (água - TFE) para facilitar a visualização.

O gráfico de padrões de estrutura secundária para a protonectina (resíduos 1 a 12) e protonectina 1-6 (resíduos 14 a 18) está apresentado na figura 4.1.1. Ele está dividido em duas partes: de 0 a 150 ns e de 150 a 330 ns. Por essa figura verifica-se que a protonectina, inicialmente se apresenta em conformações em $\alpha$-hélice (até aproximadamente $36 \mathrm{~ns}$ ) e posteriormente adota conformações em Turn com B-bridge e estas dominam até o fim da simulação. Já a protonectina 1-6, se apresenta em coil durante quase toda a simulação com exceção do período de 210 a 306 ns, no qual ela adota conformação em turn com b-bridge. 

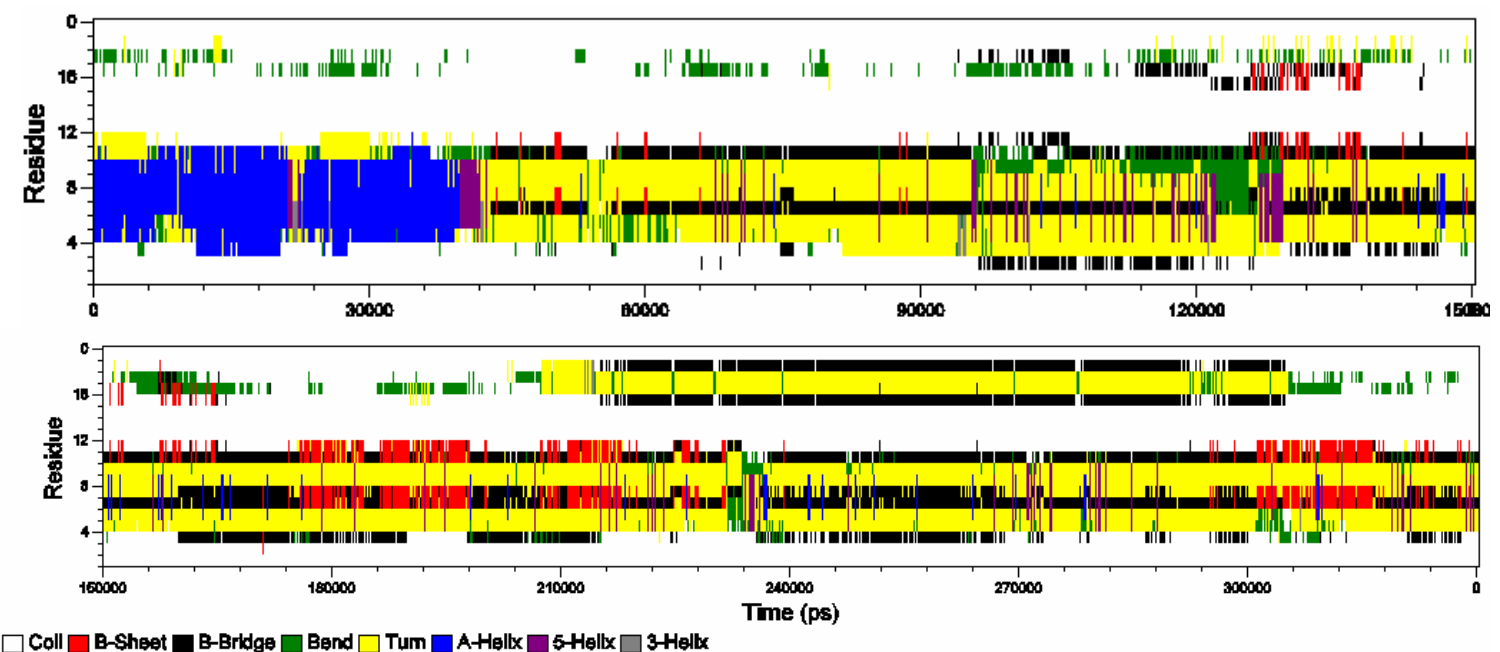

FIGURA 4.1.: Gráfico de Padrões de Estrutura Secundária para a simulação da Protonectina associada com Protonectina 1-6 em T=299K. Em azul resíduo em alfa hélice, em branco resíduo em conformação aleatória, em preto resíduo em b - bridge, em vermelho resíduo em folha beta, em verde resíduo em curva, em amarelo resíduo em turn, em roxo resíduo em hélice-5, em cinza resíduo em hélice-3.

As ligações pelo hidrogênio entre os grupos carbonila e amida da cadeia principal são um indicativo de estruturação dos peptídeos. Na Tabela 4.1 estão apresentados os dados obtidos para o tempo médio de permanência dessas ligações entre resíduos $n-n+4$ e $n-n+$ 5 para a simulação dos peptídeos associados e, para comparação das simulações com o peptídeo isolado, conforme apresentado no capitulo 3. Nesse caso foi assumido que o conjunto de simulações 1 a 6 constituem um ensemble e os valores médios foram obtidos considerando-se o tempo total das seis simulações.

O principal resultado desse quadro é que, com a associação dos dois peptídeos, duas novas ligações pelo hidrogênio entre grupos $\mathrm{CO}$ e $\mathrm{NH}$ entre resíduos $\mathrm{n}-\mathrm{n}+5$, respectivamente, aparecem. Elas ocorrem entre o CO do resíduo 5 e o NH do resíduo 10, com um percentual de permanência de cerca de $70 \%$ do tempo de simulação e entre o CO do resíduo 7 com o $\mathrm{NH}$ do resíduo 12, embora nesse caso com um percentual pequeno do tempo de simulação. Os percentuais para as ligações entre os resíduos 3 - 8 e 4 - 9, que haviam sido observados nas simulações com a protonectina isolada, são maiores, mas é preciso cuidado com a interpretação desse resultado, pois os dados para a associação se referem a uma única simulação de equilíbrio, enquanto para a protonectina isolada eles são fruto da média sobre seis simulações distintas. Os dados indicam, contudo, que a presença da protonectina 1-6 
parece promover a estabilização da estrutura secundária, pois como vimos no capitulo anterior, uma das simulações partindo de um percentual pouco menor de hélice- $\alpha$ não se estabilizou, tendo a estrutura inicial sido completamente perdida com a evolução da simulação. Na situação de associação o conjunto evolui da estrutura parcialmente helicoidal para a protonectina, para a estrutura contendo "turns e B-bridge", passando, por breve período, pela hélice-5, um comportamento parecido com o obtido na réplica em $299 \mathrm{~K}$, figura 3.1.5. Os resultados da tabela 4.1 indicam que as ligações pelo hidrogênio do tipo $n-n+4$ têm porcentagens de permanências praticamente iguais entre a protonectina associada e a isolada, porém as ligações $n-n+5$ são significativamente mais permanentes no peptídeo associado. Pode-se ressaltar ainda que a ligação por hidrogênio entre os resíduos 5 -10 (n - n + 5) que ocorre por cerca de $70 \%$ do tempo de simulação da Protonectina associada, não é observada para a Protonectina isolada, tal fato evidencia uma maior estruturação da Protonectina para o sistema associado.

TABELA 4.1: Tempo de permanência das ligações de hidrogênio do tipo $n-n+4$ e $n-n+5$ ao longo das simulações da Protonectina isolada (capitulo 3) e da Protonectina associada com a Protonectina 1-6.

\begin{tabular}{|c|c|c|c|c|c|c|c|c|}
\hline $\begin{array}{l}\text { Ligação } \\
\mathbf{n}-\mathbf{n}+\mathbf{4}\end{array}$ & $\mathbf{1 - 5}$ & $\mathbf{2 - 6}$ & $\mathbf{3 - 7}$ & $\mathbf{4 - 8}$ & $\mathbf{5 - 9}$ & $\mathbf{6 - 1 0}$ & $\mathbf{7 - 1 1}$ & $\mathbf{8 - 1 2}$ \\
\hline PROTO ISOLADA & --- & $\sim 2 \%$ & $\sim 6 \%$ & $\sim 12 \%$ & $\sim 15 \%$ & $\sim 13 \%$ & $\sim 10 \%$ & --- \\
\hline PROTO ASSOCIADA & --- & $\sim 13,5 \%$ & $\sim 7,5 \%$ & $\sim 10 \%$ & $\sim 13 \%$ & $\sim 9 \%$ & $\sim 4,4 \%$ & --- \\
\hline $\begin{array}{c}\text { Ligação } \\
\mathbf{n}-\mathbf{n}+\mathbf{5}\end{array}$ & $\mathbf{1 - 6}$ & $\mathbf{2 - 7}$ & $\mathbf{3 - 8}$ & $\mathbf{4 - 9}$ & $\mathbf{5 - 1 0}$ & $\mathbf{6 - 1 1}$ & $\mathbf{7 - 1 2}$ & $* * * * *$ \\
\hline PROTO ISOLADA & --- & --- & $\sim 28 \%$ & $\sim 30 \%$ & --- & --- & -- & $* * * * *$ \\
\hline \begin{tabular}{c} 
PROTO ASSOCIADA \\
\hline
\end{tabular} & --- & --- & $\sim 63 \%$ & $\sim 68,5 \%$ & $\sim 70 \%$ & --- & $\sim 14 \%$ & $* * * * *$ \\
\hline
\end{tabular}

As ligações de hidrogênio entre a protonectina e os átomos de oxigênio das moléculas de TFE e água foram investigadas e os resultados são apresentados na tabela 4.2: 
TABELA 4.2.: Porcentagem de permanência das Ligações de hidrogênio entre o grupo NH de cada resíduo da cadeia principal da protonectina e as moléculas de TFE.

Para a simulação da protonectina associada com a protonectina 1-6

PROTONECTINA

\begin{tabular}{|l|l|l|c|c|c|c|c|c|c|c|}
\hline NH2 & NH3 & NH4 & NH5 & NH6 & NH7 & NH8 & NH9 & NH10 & NH11 & NH12 \\
\hline$\sim 69 \%$ & $\sim 61 \%$ & $\sim 25 \%$ & $\sim 14 \%$ & $\sim 38 \%$ & $\sim 6,7 \%$ & $\sim 11,6 \%$ & $\sim 5,3 \%$ & --- & $\sim 53,6 \%$ & $\sim 52,3 \%$ \\
\hline
\end{tabular}

PROTONECTINA 1-6

\begin{tabular}{|c|c|c|c|c|c|}
\hline NH1 & NH2 & NH3 & NH4 & NH5 & NH6 \\
\hline$\sim 83,3 \%$ & $\sim 44 \%$ & $\sim 60 \%$ & $\sim 31 \%$ & $\sim 38 \%$ & $\sim 45 \%$ \\
\hline
\end{tabular}

O tempo de permanência das ligações de hidrogênio entre os grupos de $\mathrm{NH}$ da Protonectina e o oxigênio das moléculas de TFE apresentados na tabela acima têm valores baixos se comparados com os valores observados para a Protonectina isolada (tabela 3.2.4. simulações 1 e 2). Os percentuais de permanência só são significativos para as extremidades da Protonectina (resíduos 2, 3, 11 e 12). Os valores de tempo de permanência das ligações por hidrogênio entre o grupo NH da cadeia principal da Protonectina 1-6 e os átomos de oxigênio das moléculas de TFE são altos quando comparados com os mesmos valores para a Protonectina. Eles são baixos, quando comparados aos valores obtidos para a Protonectina isolada nas simulações 1 e 2 (tabela 3.2.4). A ligação por hidrogênio entre a Protonectina e Protonectina 1-6 associadas com as moléculas de água ocorrem esporadicamente, por isso seus resultados não estão sendo apresentados.

Dessa análise pode-se concluir que a associação dos peptídeos afasta consideravelmente as moléculas de TFE da região da cadeia principal da Protonectina, reforçando as ligações de hidrogênio do tipo $n-n+5$ e blindando a glicina 7 do contato com o solvente, como mostra a tabela 4.2, de onde se pode notar a diminuição da porcentagem de permanência da ligação de hidrogênio do NH7 com o TFE.

Outro aspecto relevante é a existência de ligações pelo hidrogênio entre grupos polares intercadeias. Considerando que o único resíduo com cadeia lateral polar da Protonectina 1-6 é a treonina 4, fixamos nossa procura por ligações entre os grupos carbonila da cadeia principal de uma molécula com os grupos amina, da cadeia principal, da outra e vice-versa. Os dados estão dispostos nas Figuras 4.2A e vice-versa Figura 4.2B, respetivamente, como função do tempo de simulação. Os resultados revelam que a partir de aproximadamente 100 ns até o fim 
da simulação, com exceção dos períodos de aproximadamente 175 a 230 ns e 300 a 325 ns, há a ocorrência deste tipo de ligação entre os dois peptídeos. Nos períodos nos quais não há ocorrência de ligações de hidrogênio entre os dois peptídeos, a conformação que prevalece para a Protonectina apresenta alguns resíduos em turn e outros em folha beta. Se cada uma das ligações de hidrogênio que ocorrem entre os dois peptídeos fosse avaliada individualmente, as porcentagens de permanência apresentariam valores quase insignificantes, no entanto, se todas estas pequenas contribuições forem somadas, observa-se que a interação por hidrogênio entre estes dois peptídeos é relevante. A formação destas ligações permite inferir uma associação entre os dois peptídeos que pode ser responsável pelo aumento de estrutura da protonectina em relação à protonectina isolada, favorecendo os mecanismos de interação deste peptídeo com membranas biológicas. No entanto, não se pode descartar a possibilidade desse efeito resultar de um aumento do tamanho da cadeia. A figura 4.3 é o resultado da soma das ligações de hidrogênio que ocorrem entre os dois peptídeos e que são apresentadas nas figuras 4.2 .
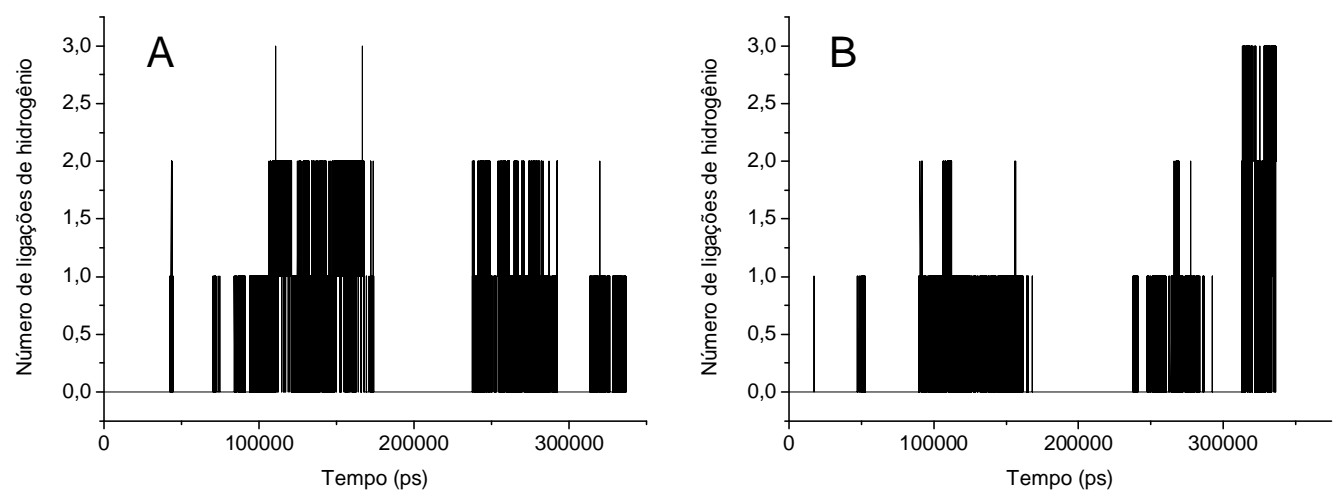

FIGURA 4.2: Número de ligações de hidrogênio entre a Protonectina e a Protonectina 1-6. A) soma das ligações entre o grupo CO dos resíduos de aminoácido da Protonectina com o grupo NH dos resíduos de aminoácidos da

Protonectina 1-6. B) soma das ligações entre o grupo NH dos resíduos de aminoácido da Protonectina com o grupo CO dos resíduos de aminoácidos da Protonectina 1-6. 


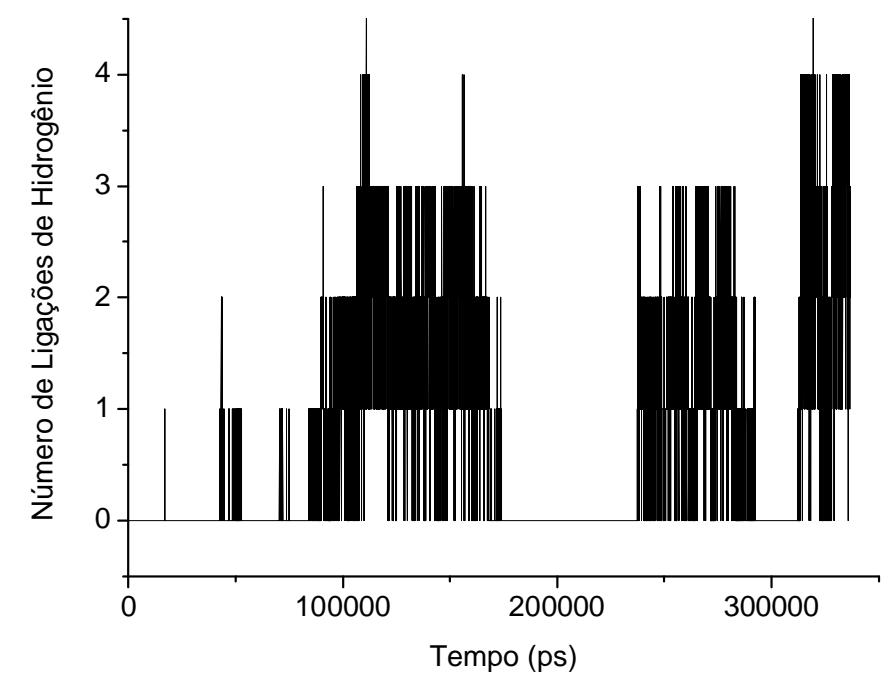

FIGURA 4.3: Soma do número de ligações de hidrogênio entre a Protonectina e a Protonectina 1-6.

Analisando as figuras acima, desconsiderando os primeiros $100 \mathrm{~ns}$, verifica-se em média que 1,1 ligações por hidrogênio estão formadas durante o tempo de simulação. Algumas destas ligações são estáveis por períodos relativamente longos da dinâmica, por exemplo, o grupo CO da Leu 9 da Protonectina com o grupo NH da Thr 4 da Protonectina 16; o grupo NH da Gly 11 da Protonectina com grupo CO da Leu 2 da Protonectina 1-6 (no que segue essa notação será sempre seguida, ou seja, o primeiro grupo é sempre pertencente a protonectina e o segundo pertencente a protonectina 1-6) e enquanto outras têm pequenas durações em torno de uma mesma região, como é o caso das ligações: $\mathrm{CO}$ (Gly 7) - NH (Leu 2); CO (Gly 7) - NH (Gly 3); CO (Leu 6) - NH (Leu 6); CO (Leu 12) - NH (Leu 2); CO (Leu 12) - NH (Ile 5); CO (Leu 12) - NH (Leu 6); NH (Gly 11) - CO (Thr 4); NH (Gly 11) - CO (Leu 2); entre outras.

A distância entre o centro de massa da Protonectina e o centro de massa da Protonectina 1-6 como função do tempo de simulação foi calculada e é apresentada na figura 4.4. Da análise conjunta com a figura 4.3, percebe-se que os intervalos de tempo nos quais ligações de hidrogênio entre os dois peptídeos estão formadas (figura 4.3) são os intervalos em que os centros de massa dos peptídeos encontram-se mais próximos, como era esperado. 


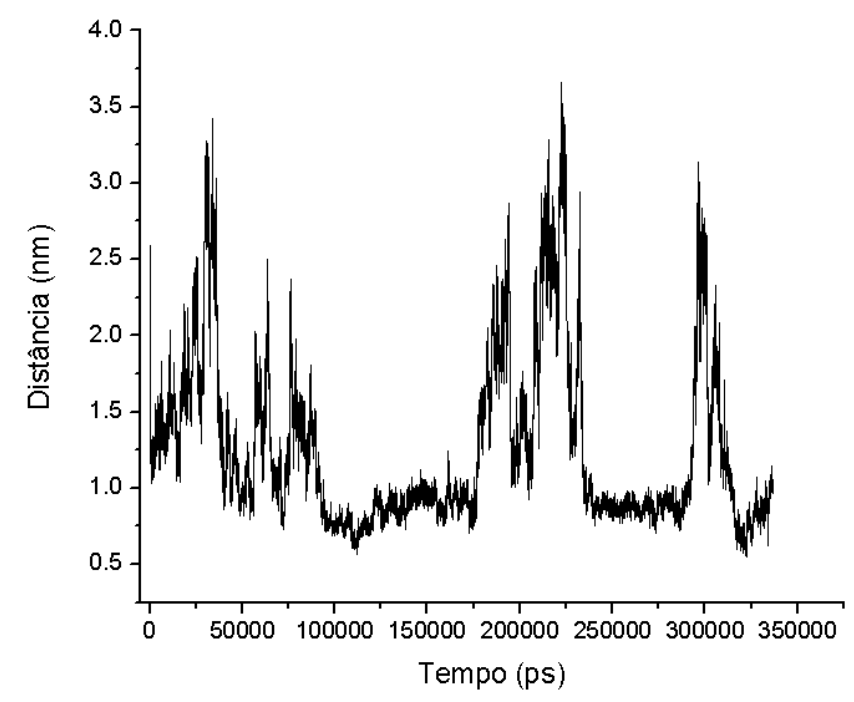

FIGURA 4.4: Distância entre o centro de massa da Protonectina e o centro de massa da Protonectina 16 como função do tempo de simulação.

Essa observação também pode ser comprovada pela energia potencial total entre os dois peptídeos, mostrada na figura 4.5, da qual nota-se que ocorrem flutuações significativas nos valores de energia, que sugerem que ou há um equilíbrio dinâmico entre os dois peptídeos, ou que uma configuração estável para essa associação ainda não foi alcançada nesse tempo de simulação. De qualquer forma, a energia potencial é menor quando as distâncias entre os centros de massa são menores, situação em que ocorrem as ligações de hidrogênio e uma diminuição da quantidade de moléculas de solvente entre os dois peptídeos. A análise detalhada das contribuições energéticas mostra que as diferenças principais vêm das interações eletrostáticas (Coulomb) e de tipo Lennard Jones entre átomos que estão dentro da esfera de raio de corte $(\sim 1,4 \mathrm{~nm})$. 


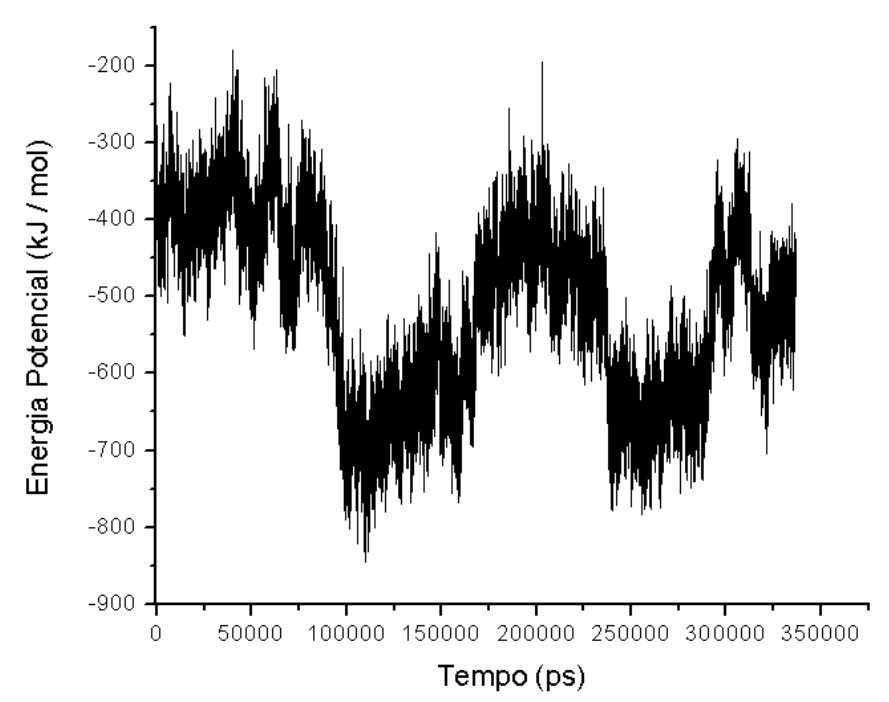

FIGURA 4.5: Energia Potencial Total entre a Protonectina e a Protonectina 1-6.

Na figura 4.6 mostramos como a Protonectina 1-6 se posiciona em relação à Protonectina num instante da dinâmica, no qual duas das possíveis ligações por hidrogênio estão formadas entre os dois peptídeos. Nela estão destacadas as ligações entre o grupo CO da Leu 9 com NH da Thr 4 e o grupo NH da Gly 11 com CO da Leu 2.

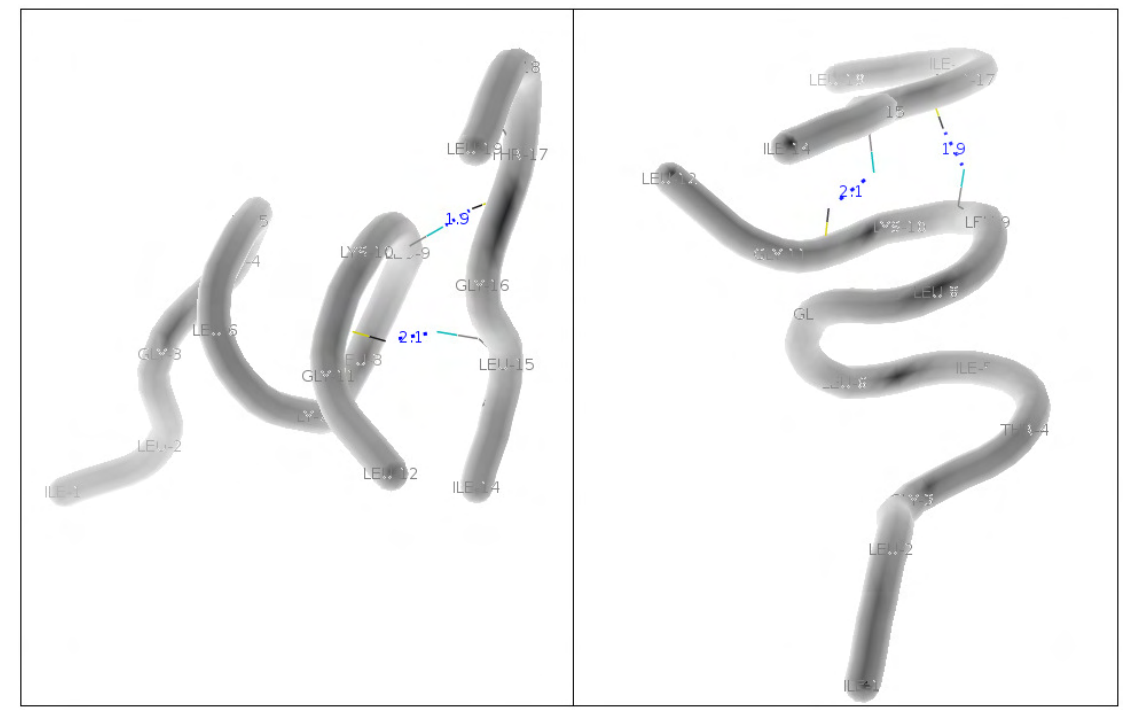

FIGURA 4.6.: Disposição dos peptídeos protonectina e protonectina 1-6 no instante de 135375 ps, visto de dois ângulos distintos. Em azul claro estão representados os grupos de $\mathrm{NH}$, e em preto, átomos de oxigênio constituintes dos grupos que participam das ligações de hidrogênio, que está enfatizada em pontilhados em azul escuro, os números representam a distância (nm) entre os grupos. 
Os dados obtidos indicam que a associação da Protonectina com a Protonectina 1-6 favoreçe a estruturação destes peptídeos em relação aos mesmos isolados, produzindo uma maior organização do solvente ao redor da Protonectina se comparada com a simulação para a Protonectina isolada. Para verificar esta situação, foram construídas três figuras: uma que exibe o perfil de solvatação da Protonectina isolada e outras duas que exibem o perfil de solvatação para o sistema associado, figuras 4.7A, 4.7B e 4.7C, respectivamente. A figura 4.7A foi obtida a partir da análise da solvatação ao redor da conformação com 2 resíduos em B-Bridge e 4 em Turn apresentada anteriormente na figura 3.1.18A que foi obtida no primeiro mínimo de energia da simulação da Protonectina isolada. As figuras 4.7B e 4.7C foram obtidas nos instantes de 119985 ps e 135575 ps, respectivamente, da simulação da Protonectina associada com a Protonectina 1-6. Estas conformações foram escolhidas por apresentarem basicamente as mesmas características estruturais, resíduos em turn com bbridge.
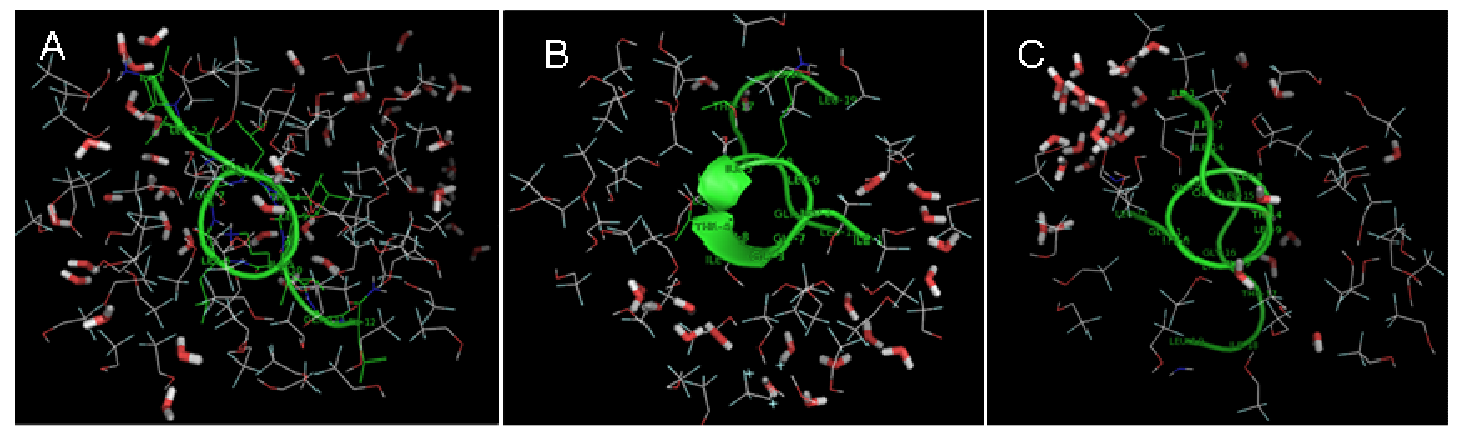

FIGURA 4.7.: A) Solvatação ao redor de $10 \AA ̊$ dos grupos Gly7 e Leu9 da Protonectina isolada. B) Solvatação ao redor de $10 \AA$ A dos grupos Gly7 e Leu9 da Protonectina associada com a Protonectina 1-6. Em verde estão apresentados os resíduos de aminoácidos da Protonectina e/ou Protonectina 1-6, as moléculas de água estão apresentadas com o oxigênio em vermelho e as pontas em cinza representam os átomos de hidrogênio. As moléculas de TFE estão com sua parte hidrofóbica apresentada em cinza e a parte hidrofílica em vermelho.

Da comparação entre as figuras 4.7 verifica-se que o solvente ao redor do sistema associado está mais organizado (figuras 4.7B e 4.7C) se comparado com a situação da Protonectina isolada (figura 4.7A), pois é evidente a formação de duas regiões: uma hidrofílica, na qual há a aproximação de moléculas de água, e uma hidrofóbica, onde há predominância de moléculas de TFE. A existência destas duas regiões confere ao sistema 
associado um caráter anfipático que, de acordo com os modelos de interação com membranas biológicas discutidos no capitulo 1, pode favorecer a interação com membrana zwiteriônicas. 


\section{Capítulo 5}

\section{CONCLUSÃO}

Neste trabalho apresentamos a análise conformacional do peptideo protonectina em mistura água-TFE e da associação da protonectina com a protonectina 1-6 nesse mesmo ambiente. O sistema foi analisado usando a simulação por dinâmica molecular de equilíbrio e fora do equilíbrio para a protonectina isolada e por dinâmica de equilíbrio para a associação dos dois peptídeos.

As simulações fora do equilíbrio tinham por objetivo varrer o espaço conformacional da protonectina no ambiente considerado e para isso fez-se uso das simulações acopladas ao método de troca de replicas, variando-se a temperatura no intervalo de 287 a $342 \mathrm{~K}$, para permitir que o sistema não ficasse preso a mínimos locais na superfície de energia. Dos dados apresentados mostrou-se que a protonectina apresenta pelo menos três conformações estruturadas que podem ser encontradas na região de mínima energia livre (figura 3.1.18), são elas: conformação em hélice-5, conformação em "turn com b-bridge" e conformação em $\alpha$-hélice. A semelhança entre estas conformações pode ser considerada alta entre as duas primeiras e razoável entre estas e a alfa hélice (ver tabela 3.1.1). A análise com o Wham permitiu estimar o tempo de transição em cerca de 165 ns.

As simulações de equilíbrio apontaram para a estabilidade das conformações em hélice-5 e "turn com b-bridge", que pode ser explicada porque a ocorrência delas é simultânea à formação e manutenção de ligações por hidrogênio entre alguns resíduos centrais da protonectina e de grupos amina dos demais resíduos com o oxigênio das moléculas de TFE. Em outras palavras os dados indicam que a distribuição do solvente, em particular, das moléculas de TFE, em torno da cadeia principal do peptídeo é fundamental para estabilizar essas conformações.

Com o procedimento proposto e discutido no capitulo 3 se obtêm percentuais de conformações em helice- $\alpha$ "direita" que estão em boa concordância com os dados experimentais de dicroísmo circular.

Dos resultados das dinâmicas contendo os dois peptídeos em associação 1:1 (Protonectina e Protonectina 1-6), verificou-se que a Protonectina 1-6 associa-se a Protonectina pela região do $\mathrm{C}$ terminal. Da análise de ligações pelo hidrogênio de grupos carbonila e/ou amina da Protonectina com grupos amina e/ou carbonila da 
Protonectina 1-6, respectivamente, verificou-se que em cerca de $62 \%$ do tempo de dinâmica (excluído os 100 primeiros ns), existe pelo menos uma ligação intercadeias entre estes peptídeos. No intervalo de 120 a 180 ns duas ligações por hidrogênio, mostram-se bastante estáveis e esta associação pode ser verificada pelas ligações de hidrogênio formadas entre as cadeias ao longo do período da dinâmica em que ambos os peptídeos estão aproximados. A partir de aproximadamente 120 ns até 180 ns, verificam-se duas ligações de hidrogênio, entre os grupos CO (Leu9) - NH (Thr17 4) e NH (Gly7) - CO (Leu15 2) bastante estáveis, coexistindo em cerca de $34 \%$ desse intervalo e ao menos uma delas está formada em cerca de $83 \%$ desse intervalo.

A associação entre os dois peptídeos parece induzir um aumento na quantidade de resíduos com alguma conformação estruturada na Protonectina, além disso, o valor para a energia potencial entre os dois peptídeos, nos intervalos onde ocorre a interação (por pontes de hidrogênio) entre eles, é o menor observado. Tais observações podem estar correlacionadas ao fato de que a Protonectina 1-6 protege, do meio externo, os resíduos do C-terminal da Protonectina.

A conformação que prevalece durante o período em que o complexo está formado é a de turn com b-bridge.

A solvatação em torno da Protonectina isolada e dela associada com a protonectina 1-6 revela que em torno da Protonectina isolada ocorre a estruturação do solvente, mas não a formação de uma estrutura anfipática, enquanto que para o sistema associado o solvente, distribui-se em duas regiões: uma hidrofílica, com presença significativa de moléculas de água e outra hidrofóbica com predominância de moléculas de TFE. A região hidrofílica se dá em torno de resíduos polares, com ou sem carga e a região que concentra os resíduos de glicina.

A presença de resíduos de glicina nas posições 3, 7 e $11(n-n+4)$ dificulta a estruturação helicoidal deste peptídeo típica de peptídeos antimicrobianos, por permitir a aproximação de moléculas de solvente na região da cadeia principal destes resíduos. 


\section{REFERÊNCIAS BIBLIOGRÁFICAS}

ALLEN M. P.; TILDSLEY D. J. Computer Simulation of Liquids. Oxford Science Publications, 1987.

ARGIOLAS A.; PISANO J. J. Facilitation of Phospholipase A2 Activity by Mastoparans, a New Class of Mast Cell Degranulating Peptides from Wasp Venom, Journal of Biological Chemistry, Baltimore, v. 258, p. 13697-13702, 1983.

Atkins P. W. Fundamentos de Físico-Química, 3 edição, Rio de Janeiro: LTC, 2003.

BERENDSEN H. J. C. et. al., Interaction models for water in relation to protein hydration, in: Intermolecular Forces, Dordrecht, Reidel Publishing, p. 331-342, 1981.

BERENDSEN H. J. C. et al., Molecular Dynamics with coupling to an external bath, Journal of Chemical Physics, New York, v. 81, p. 3684-3690, 1984.

BROGGIO COSTA S. T. Estudos Conformacionais por Dinâmica Molecular de Peptídeos Antimicrobianos da Família dos Mastoparanos em Misturas de TFE-água. 2006. 155 f. Tese (Doutorado)-Instituto de Biociências, Letras e Ciências Exatas de São José do Rio Preto, Universidade Estadual Paulista Julio de Mesquita Filho, São José do Rio Preto, 2006.

BROOKS B. R. et al., A program for macromolecular energy minimization and calculations, Journal of Computational Chemistry, Hoboken, v. 4, p. 187-217, 1983.

BROOKS III C. L.; KARPLUS M.; PETTITT B. M. Proteins: a theoretical perspective of dynamics, structure and thermodynamics, Advances in chemical physics, New York: John Wiley \& Sons, LXXI, 1998.

DATHE M. et al., Optimization of the antimicrobial activity of magainin peptides by modification of charge, Federation of European Biochemical Sociocietets, Amsterdam, v. 50, p. 146-150, 2001.

de Souza et al., Structural and functional characterization of two novel peptide toxins isolated from the venom of the social wasp Polybia paulista, Peptides, New York, v. 26, p. 2157-2164, 2005 
DOS SANTOS CABRERA et al., Conformation and lytic activity of eumenine mastoparan: a new antimicrobial peptide from wasp venom, Journal of Peptide Research, Copenhagen, v. 64, p. 95-103, 2004.

DOS SANTOS CABRERA et al., Selectivity in the mechanism of action of antimicrobial mastoparan peptide Polybia-MP1, European biophysics journal, Berlin, v. 37, p. 879-891, 2008.

DOS SANTOS CABRERA et al., Interactions of mast cell degranulating peptides with model membranes: A comparative biophysical study, Archives of Biochemistry and Biophysics, New York, v. 486, p. 1-11, 2009.

EISENBERG D.; SCHWARZ E.; KOMAROMY M.; WALL R. Analysis of membrane and surface protein sequences with hydrophobic moment plot, Journal of Molecular Biology, London, v. 179, p. 125$142,1984$.

FIORONI M. et al. A new 2,2,2-trifluoroethanol model for molecular dynamics simulations, Journal of Physical Chemistry, Washington, v. 104, p. 12347-12354, 2000.

HESS B. et al. LINCS: a linear constraint solver for molecular simulations, Journal of Computational Chemistry, Hoboken, v. 18, p. 1463-1472, 1997.

HORI Y. et al. Interaction of mastoparan with membranes studied by H-NMR spectroscopy in detergent micelles and by solid-state H-NMR and N-NMR spectroscopy in oriented bilayers, European biophysics journal, Berlin, v. 268, p. 302-309, 2001.

KUMAR S. et al. The weighted histogram analysis method for free-energy calculations on biomolecules. I. The method, Journal of Computational Chemistry, Hoboken, v. 13, p. 1011-1021, 1992.

KUMAR S. et al. Multidimensional Free-Energy Calculations Using The Weighted Histogram Analysis Method, Journal of Computational Chemistry, Hoboken, v. 16, p. 1339-1350, 1995.

LINDAHAL E.; HESS B.; VAN DER SPOEL D. Gromacs 3.0: a package for molecular simulations and trajectory analysis, Journal of Molecular Modeling, Berlin, v. 7, p. 306-317, 2001.

LINDSAY I. S. A tutorial on Principal Components Analysis, 2002. 
LINS R. D.; RÖTHLISBERGER U. Influence of Long-Range Eletrostatic Treatments on the Folding of the N-Terminal H4 Histone Tail Peptide, Journal of Chemical Theory and Computation, Washington, v. 2, p. 240-250, 2006.

MATSUZAKI K. et al. An Antimicrobial Peptide, Magainin 2, Induced Rapid Flip-Flop of Phospholipids Coupled with Pore Formation and Peptide Translocation, Biochemistry, Washington, v. 35, p. 11361-11368, 1996.

MATSUZAKI K. et al. Interactions of an antimicrobial peptide, Magainin2, with outer and inner membranes of Gram-negative bacteria, Biochimica et Biophysica Acta, Amsterdam, v. 36, p. 97999806, 1997.

MATSUZAKI K. Control of cell selectivity of antimicrobial peptides, Biochimica et Biophysica Acta, Amsterdam, v. 1788, p. 1687-1692, 2009.

MÁTYUS E.; KANDT C.; TIELEMAN P. Computer Simulation of Antimicrobial Peptides, Current Medicinal Chemistry, Schiphol, v. 14, p. 2789-2798, 2007.

MENDES M. A. et al. Structural and biological characterization of two novel peptides from the venom of the neotropical social wasp Agelaia pallipes pallipes, International Society of Toxicology, Oxford, v. 44, p. 67-74, 2004.

MIYAMOTO S.; KOLLMAM P. A. SETTLE: an analytical version of the SHAKE and RATTLE algorithm for rigid water models, Journal of Computational Chemistry, Hoboken, v. 13, p. 952-962, 1992.

MURATA K. et al. Novel Biologically Active Peptides from the Venom of Polistes rothneyi iwatai, Biological \& Pharmaceutical Bulletin, Tokyo, v. 29, p. 2493-2497, 2006.

MURATA K. et al. Novel mastoparan and protonectin analogs isolated from a solitary wasp, Orancistrocerus drewseni drewseni, Amino Acids, Wien, v. 37, p. 389-394, 2009.

OREN Z:; SHAI Y. Mode of action of linear amphipathic $\alpha$-helical antimicrobial peptides, Biopolymers, New York, v. 47, p. 451-463, 1998. 
RHEE Y. M.; PANDE V. S. Multiplex-Replica Exchange Molecular Dynamics Method for Protein Folding Simulation, Biophysical Journal, New York, v. 84, p. 775-786, 2003.

ROCCATANO D. et al. Mechanism by which 2,2,2-trifluoroethanol/water mixtures stabilize secondarystructure formation in peptides: A molecular dynamics study, Proceedings of the national academy of sciences of the United States of America, Washington, v. 99, p. 12179-12184, 2002.

ROHL C. A.; BALDWIN R. L. Deciphering rules of helix stability in peptides, Methods in enzymology, New York, v. 295, p. 1-26, 1998.

Saidemberg N. B. B. Efeito das Interações Peptídeo-Peptídeo e Peptídeo-Membrana nas Atividades Funcionais de Toxinas Peptídicas do Veneno da Vespa Social Agelaia pallipes pallipes (Hymenoptera, Vespidae), 2007. Dissertação (Mestrado) - Programa de Pós-Graduação em Biologia Celular e Molecular, Universidade Estadual Paulista Júlio de Mesquita Filho, Rio Claro, 2007.

SOUZA B. M. et al. Structural and functional characterization of two novel peptide toxins isolated from the venom of the social wasp Polybia paulista, Peptides, New York, v. 26, p. 2157-2164, 2005.

SUGITA Y.; OKAMOTO Y. Replica-exchange molecular dynamics method for protein folding, Chemical physics letters, Amsterdam, v. 314, p. 141-151, 1999.

TOSSI A.; SANDRI L.; GIANGASPERO A. Amphipatic, $\alpha$-helical antimicrobial peptides, Biopolymers, New York, v. 55, p. 4-30, 2000.

VAN GUNSTEREN W. F.; BERENDSEN H. J. C. Gromos87 Library Manual BIOMOS Groningen, Netherlands, 1987.

VAN GUNSTEREN W. F. et al. Biomolecular Simulation: The GROMOS96 Manual and User Guidem; vdf Hochschulverlag ETH Zürich, Switzerland, 1996.

VERLET L. Computer "Experiments" on Classical Fluids. I. Thermodynamical Properties of LennardJones Molecules, Physical review letters, New York, v. 159, p. 98-103, 1967.

VETTER R. S.; VISSCHER P. Bites and stings of medically important venomous arthropods, International Journal of Dermatology, Philadelphia, v. 37, p. 481-496, 1998. 
YANG L. et al. Barrel-Stave Model or Toroidal Model? A Case Study on Melittin Pores, Biophysical SocietyAmerican Physical Society, New York, v. 81, p. 1475-1485, 2001.

YEAMAN M. R.; YOUNT N. Y. Mechanisms of antimicrobial peptide action and resistance, American Society of Pharmacology and Experimental TherapeuticsBritish Pharmacological Society, Baltimore, v. 55, p. 27-55, 2003.

WEINER S. J. et al. An all atom force field simulations of proteins an nucleic acids, Journal of Computational Chemistry, Hoboken, v. 7, p. 230-252, 1996.

ZHAO $\mathrm{H}$. et al. Interactions of the antimicrobial peptides temporins with model biomembranes. Comparasion of temporins B and L, Biochemistry, Moscow, v. 41, p. 4425-4436, 2002. 


\section{APÊNDICE A}

ANÁLISE DA ENERGIA POTENCIAL DAS SIMULAÇÕES DE EQUILÍBRIO

As análises realizadas a partir dos resultados obtidos pelo método de Dinâmica Molecular devem ser promovidas em sistemas que tenham atingido o equilíbrio. Dessa forma, uma maneira de validar os resultados obtidos a partir de simulações por DM é investigar o "drift" da energia potencial desses sistemas (coeficiente angular da reta que exprime essa quantidade). $\mathrm{O}$ valor desse parâmetro está intimamente ligado com a avaliação da estabilidade do sistema em estudo. De forma que quanto menor este valor maior é o equilíbrio.

Com exceção das simulações que envolveram o método de troca de réplicas, as energias potenciais de cada simulação apresentada neste trabalho foram avaliadas e os resultados se encontram abaixo.

Simulações por dinâmica molecular associadas ao método de troca de réplicas não são exemplos de simulações de equilíbrio, pois os sistemas são permutados entre temperaturas distintas o que resulta em alterações na energia total do sistema. Este é exatamente o princípio do método: injetar energia no sistema para que ele consiga vencer as barreiras que o separam de todas as suas conformações acessíveis.

\section{Simulações de equilíbrio da protonectina isolada}

\begin{tabular}{|c|c|}
\hline & ESTRUTURA INICIAL \\
\hline SIMULAÇÃO 1 & Conformação com 5 resíduos em hélice-5 e 7 resíduos em coil. \\
\hline SIMULAÇÃO 2 & Conformação com 5 resíduos em coil, 2 em b-bridge, 1 bend e 4 em turn. \\
\hline SIMULAÇÃOO 3 & Conformação com 5 resíduos em coil, 1 bend, 2 em turn e 4 em $\alpha$-hélice \\
\hline SIMULAÇÃO 4 & Conformação com 6 resíduos em coil, 4 em folha beta e 2 em turn. \\
\hline SIMULAÇÃO 5 & Todos os resíduos em coil \\
\hline SIMULAÇÃO 6 & Conformação com 4 resíduos em coil, 1 em turn e 7 em $\alpha$-hélice \\
\hline
\end{tabular}

TABELA 1: Relação das simulações e suas respectivas conformações iniciais. 

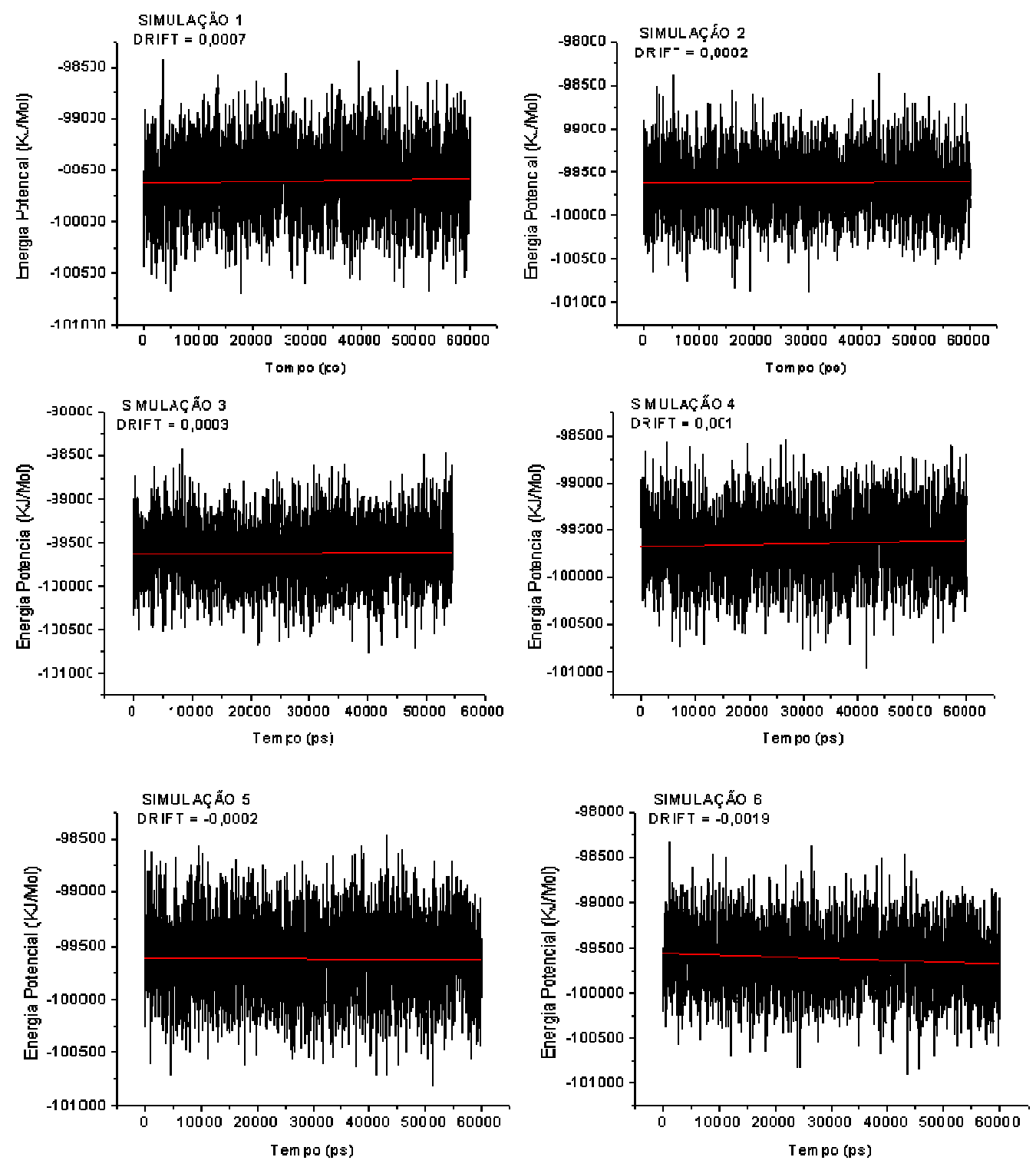

FIGURA 1: Gráficos da energia potencial (KJ/Mol) como função do tempo de simulação para cada uma das simulações de equilíbrio da protonectina. Reta em vermelho representa o FIT Linear de cada curva, o respectivo DRIFT é apresentado no canto superior esquerdo.

Pela figura acima é possível inferir que devido ao baixo valor de DRIFT apresentado pelas curvas as análises realizadas neste trabalho são confiáveis, pois os sistemas podem ser considerados equilibrados. 
2. Simulação de equilíbrio da Protonectina associada com a Protonectina 1-6

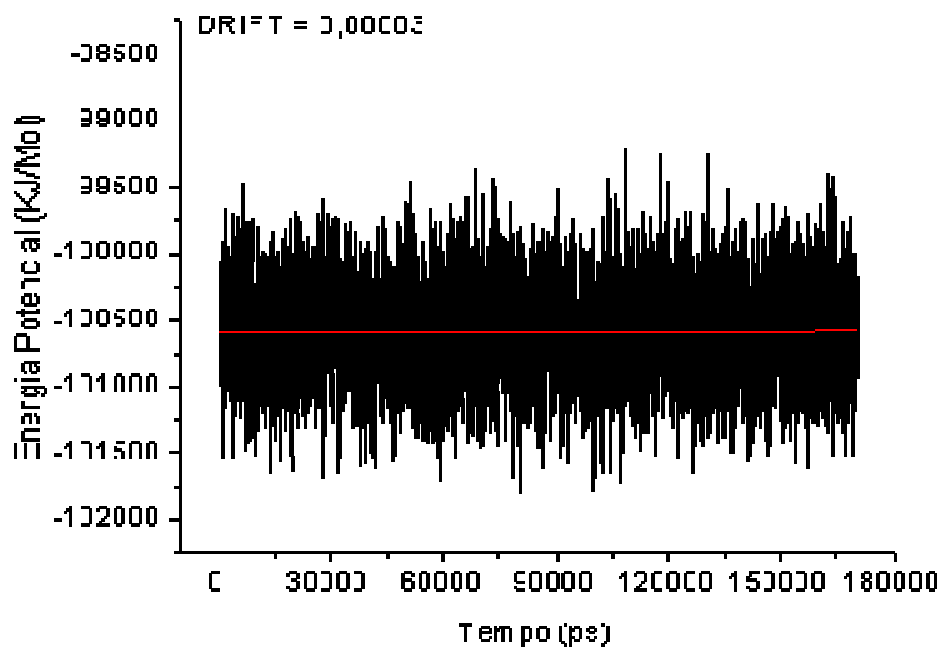

FIGURA 2: Gráfico da energia potencial (KJ/Mol) como função do tempo de simulação para a DM da protonectina associada com a protonectina 1-6. Reta em vermelho representa o FIT Linear de cada curva, o respectivo DRIFT é apresentado no canto superior esquerdo.

O DRIFT apresentado pela simulação de equilíbrio da protonectina associada com a protonectina 1-6 é o que apresentou o menor valor dentre todos os apresentados. Este é mais um caso no qual a simulação atingiu o equilíbrio esperado, o que infere às análises realizadas credibilidade. 


\section{APÊNDICE B}

\section{PARÂMETROS DA SIMULAÇÃO}

Arquivos de Entrada para a simulação da Protonectina associada ao método de troca de réplicas:

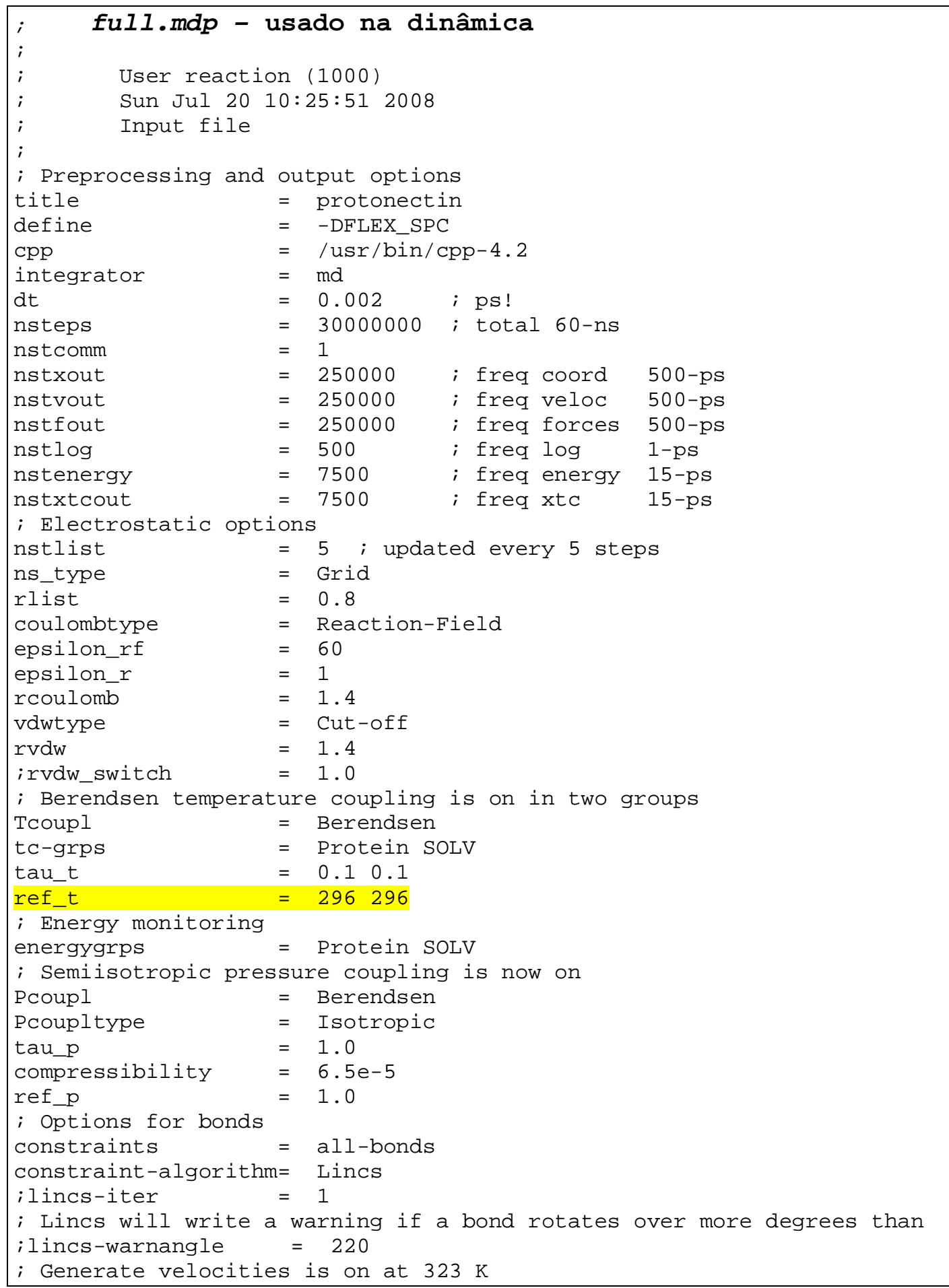




$\begin{array}{lll}\text { gen_vel } & = & \text { yes } \\ \text { gen_temp } & = & 296.0 \\ \text { gen_seed } & = & 173529\end{array}$

No método de troca de replicas é necessário montar um arquivo do tipo full.mdp para cada uma das réplicas, o que deve diferir em cada arquivo é a linha:

ref_t $=296296$

que deve conter a temperatura específica da réplica.

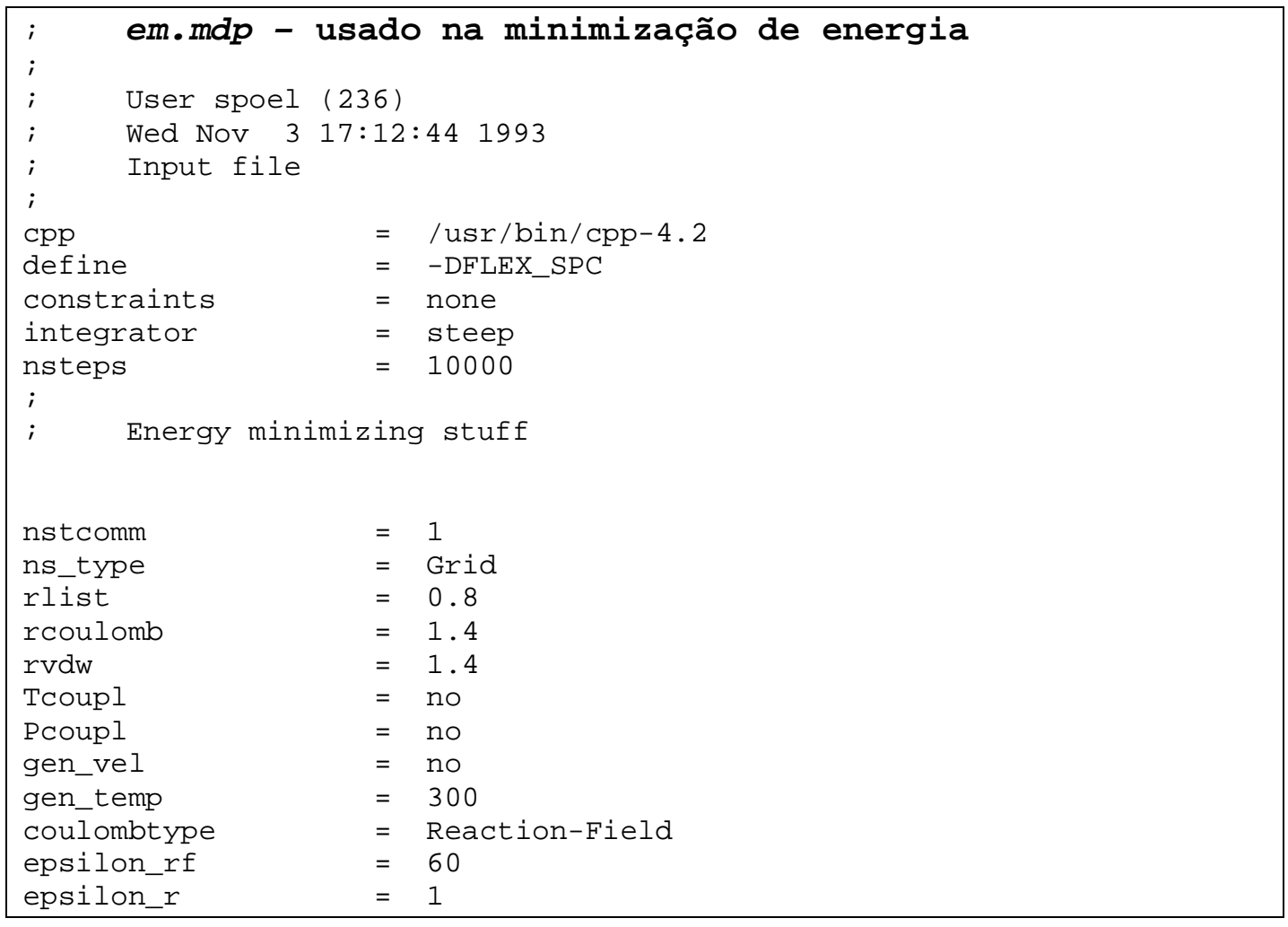

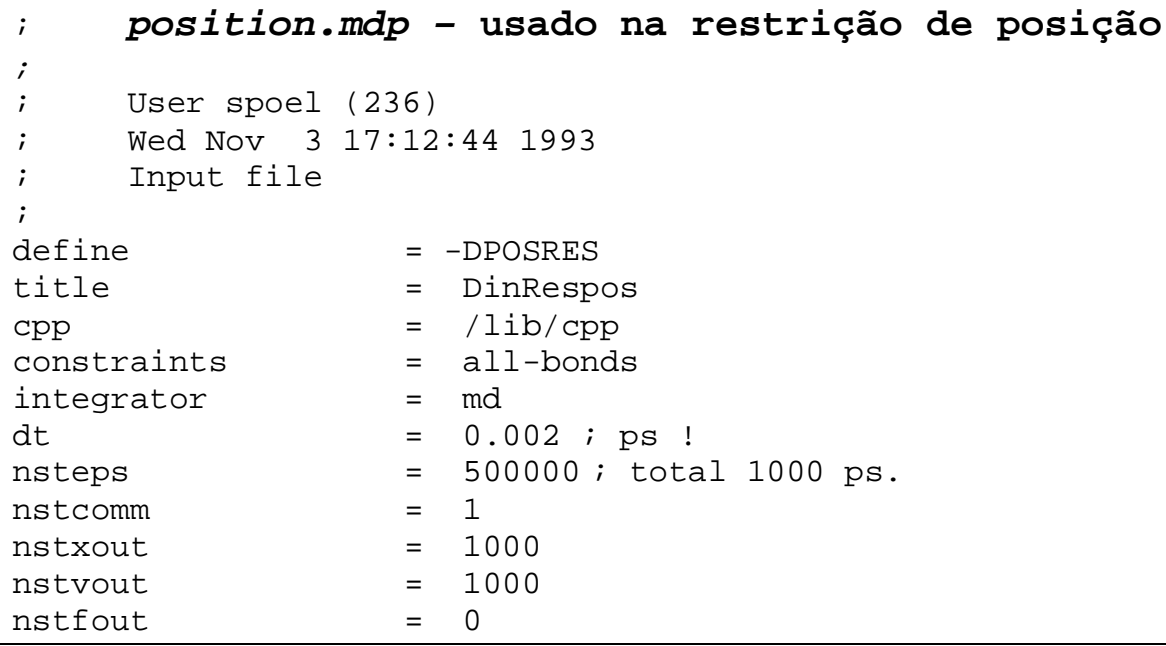




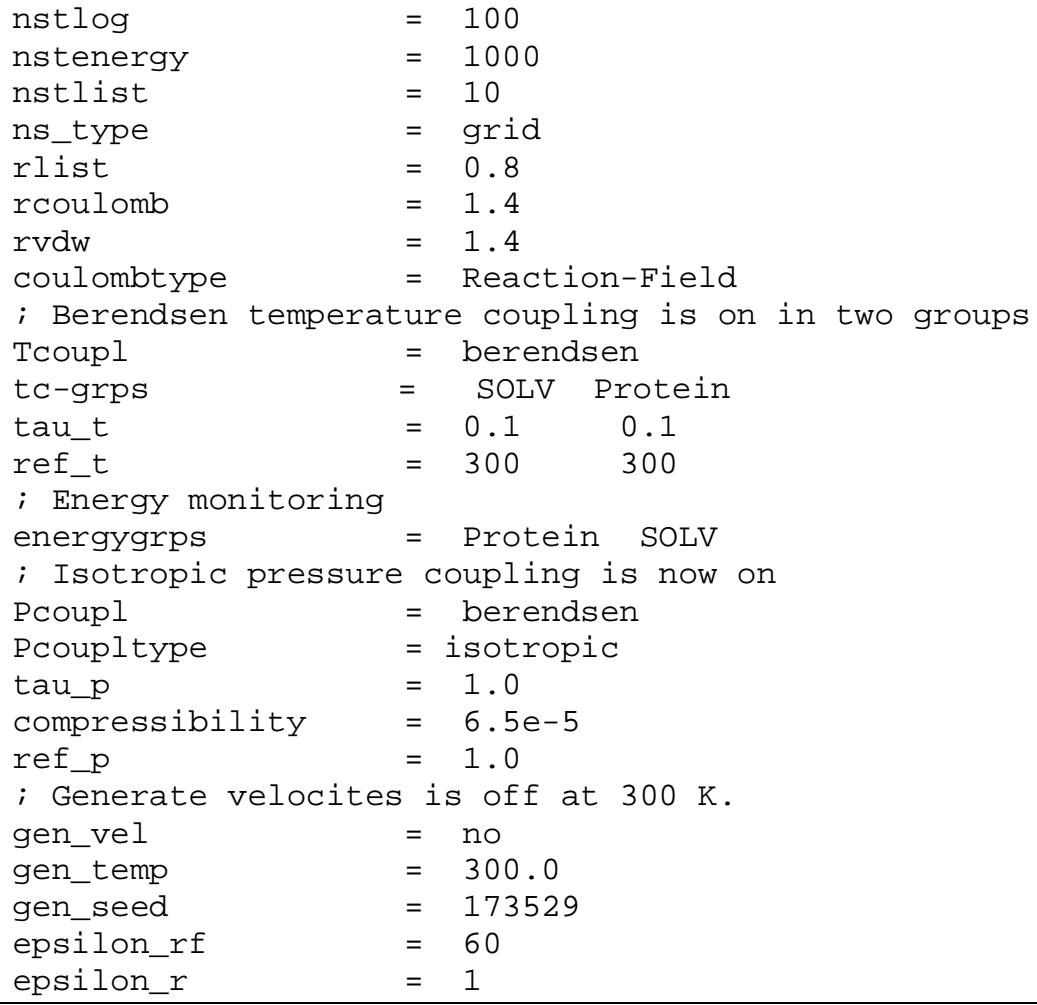

Os arquivos de entrada do tipo full.mdp utilizados na simulação de equilíbrio da Protonectina têm as mesmas características dos apresentados anteriormente, a menos de mudanças na temperatura. Para a Protonectina associada com a Protonectina 1-6 ocorrem diferenças na temperatura $(300 \mathrm{~K})$, no número de passos da simulação ( 330ns) e nos grupos utilizados em tc-groups e energygroups que são Protonectina, Protonectina1-6 e SOLV. Foram utilizados os mesmos arquivos em.mdp e position.mdp (sem quaisquer mudanças) para todas as simulações. 
Autorizo a reprodução xerográfica para fins de pesquisa.

São José do Rio Preto, ________________

Assinatura 